
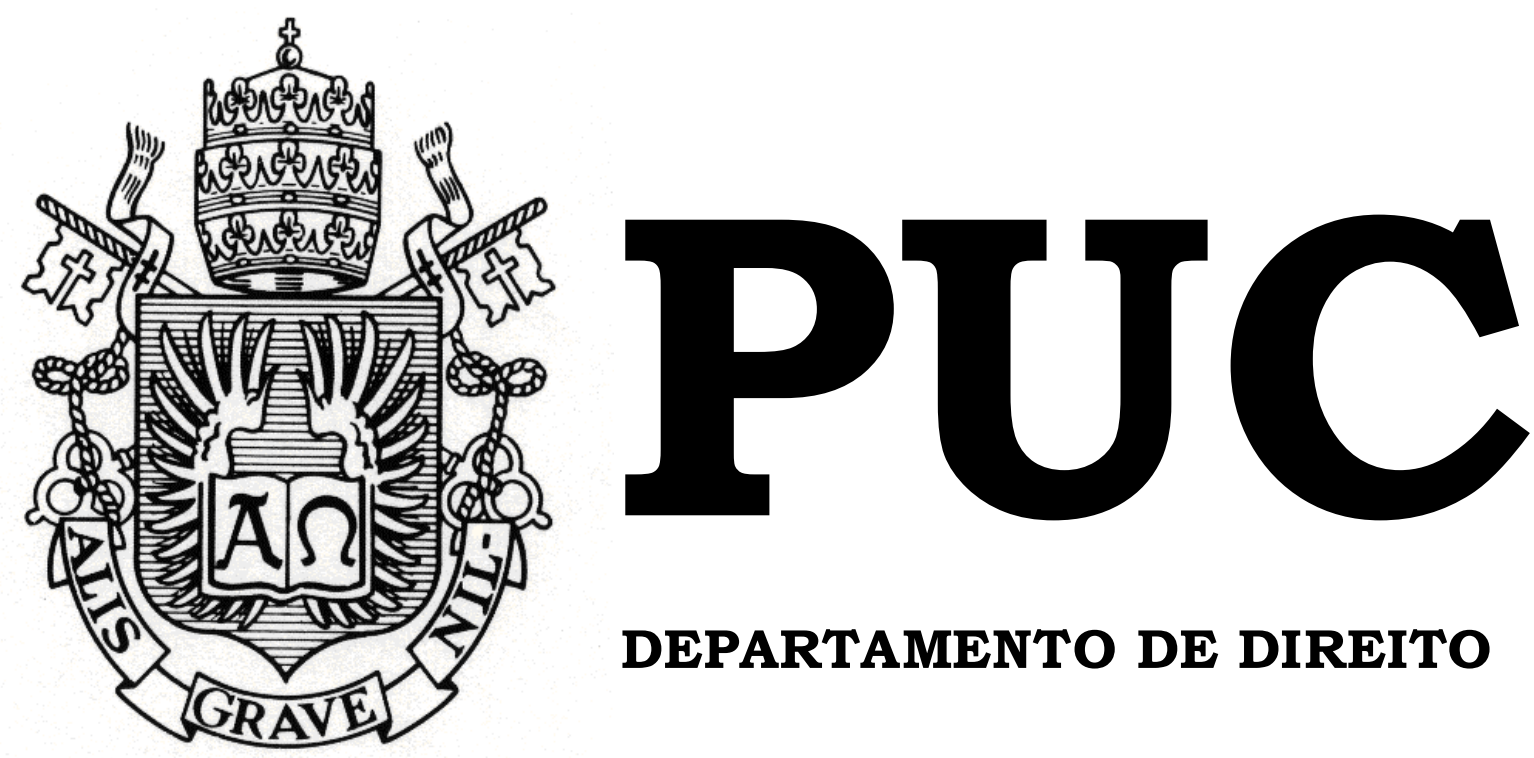

DEPARTAMENTO DE DIREITO

\title{
A LITIGÂNCIA ESTRATÉGICA NO SISTEMA INTERAMERICANO DE DIREITOS HUMANOS COMO INSTRUMENTO DE COMBATE AO TRABALHO ESCRAVO
}

\section{Por}

THAINÁ MAMEDE COUTO DA CRUZ

ORIENTADORA: Carolina de Campos Melo COORIENTADORA: Andrea Schettini

\section{1}

PONTIFÍCIA UNIVERSIDADE CATÓLICA DO RIO DE JANEIRO

RUA MARQUÊS DE SÃO VICENTE, 225 - CEP 22451-900

RIO DE JANEIRO - BRASIL 


\title{
A LITIGÂNCIA ESTRATÉGICA NO SISTEMA INTERAMERICANO DE DIREITOS HUMANOS COMO INSTRUMENTO DE COMBATE AO TRABALHO ESCRAVO
}

\author{
por \\ THAINÁ MAMEDE COUTO DA CRUZ

\begin{abstract}
Monografia apresentada ao
Departamento de Direito da

Pontificia Universidade Católica do

Rio de Janeiro (PUC-Rio) como requisito parcial para obtenção do Título de Bacharel em Direito.
\end{abstract}

Orientadora: Carolina de Campos Melo Coorientadora: Andrea Schettini 


\section{AGRADECIMENTOS}

Primeiramente, agradeço a Deus por todo o seu amor e cuidado comigo. Por ser meu melhor amigo, meu suporte e minha fortaleça em todos os momentos da minha vida. A Ele toda honra, toda glória e todo o louvor!

Aos meus amados pais, Arnaldo e Cristina, por todo o esforço, por todo o suporte e apoio, emocional e financeiro, durante a minha trajetória. Por todo amor e dedicação que acompanham todos os meus passos. Por me ensinar a confiar em Deus em todos os momentos. Devo a eles os estímulos que me permitiu caminhar firme até este momento.

Ao meu irmão, Thalles Mamede, pelo seu amor e pela compreensão. Lembre-se que eu quero sempre o seu bem.

À toda minha família, por tudo que aprendi até hoje. Obrigado por acreditarem em mim quando eu achei difícil acreditar em mim mesmo.

Ao meu namorado, Diego Pessanha, que sempre esteve ao meu lado, me ajudando nas diversas situações; pelo incentivo e pelo apoio que foram imprescindíveis. Obrigada pelo seu amor e por tornar minha caminhada mais leve e feliz!

A minha cachorrinha, Mia, companheira de estudos e de noites em claro. Também não posso esquecer da "doguinha" Lisa, sei que aonde você estiver, estará torcendo pela nossa família.

Aos meus amigos de toda a vida, aqueles que me apoiam em todos os momentos, me incentivam e torcem para a minha vitória na vida pessoal e profissional. 
Às minhas amigas da PUC-Rio, especialmente à Alexia Klingen, Ana Flávia Soares, Claudia Lopes, Isabela Pessanha, Luiza Freire, Laís Gouvêa, Maria Carolina Vieira e Paula Guedes. Vou levar vocês da faculdade para o resto da vida.

Às minhas orientadoras, Carolina de Campos Melo e Andrea Bandeira de Mello Schettini, pela excelente orientação, paciência e atenção comigo e ao meu estudo.

Ao Núcleo de Direitos Humanos da PUC-Rio, que me abriu as portas para o mundo dos direitos humanos, pelas oportunidades e aprendizados que me propiciou. Em especial as queridas, Natália Damázio e Márcia Nina Bernardes por me indicarem material de estudos de litígio estratégico.

A todos os funcionários e professores da PUC-Rio, por todas as instruções, ensinamentos e estímulos para continuar no caminho do direito e da justiça. Agradeço em especial, aos queridos Ana Paula Santoro, Ana Stern, Ilié Antonio Pele, João Batista Berthier, Juliana Bracks, Leopoldo Pereira, Regina Soares, Mariana Trotta, Mariana Montebello, Vladimir Cardoso, Thamis Dalsenter e Thula Pires.

Ao Grupo de Pesquisa Trabalho Escravo Contemporâneo (GPTEC/UFRJ) pela oportunidade de fazer parte desse grupo que muito contribuiu para elaboração desta monografia.

Aos locais e instituições que me ajudaram a desenvolver o lado prático do Direito, a Defensoria Pública do Estado do Rio de Janeiro, a Procuradoria do Instituto Estadual do Ambiente, o Escritório Denis Borges Barbosa e ao gabinete da Desembargadora Carina Rodrigues Bicalho do TRT1.

À Defensoria Pública do Estado do Rio de Janeiro, em especial à Defensora Pública Patrícia Magno e a Defensora Rivana Barreto Ricarte da Defensoria 
Pública do Acre, inspirações para mim. Agradeço também pela oportunidade de colaborar na criação e desenvolvimento do Grupo de Trabalho para Análise Estratégica de Julgados da Corte Interamericana de Direitos Humanos da Defensoria, bem como do seu futuro $1^{\text {a }}$ Caderno Estratégico.

E, por fim, agradeço também por essas pessoas que disponibilizaram o seu tempo auxiliando-me com a indicação de livros, entrevista, artigos e pesquisas. Meu muito obrigada à Adonia Antunes Prado (GPTEC/UFRJ), Ana Paula Sciammarella (Professora da UNIRIO), Beatriz Affonso (Diretora do CEJIL Brasil), Carina Bicalho (Desembargadora do TRT1), Clínica de Trabalho Escravo e Tráfico de Pessoas da Faculdade de Direito da UFMG, Frei Xavier Plassat (Coordenador da Campanha Nacional da CPT), Juliana Cesário Alvim (Fellow da FGV), Ricardo Rezende Figueira (Coordenador do GPTEC/UFRJ) e Ulisses Dias de Carvalho (Procurador do MPT e vice-coordenador nacional da Coordenadoria de Erradicação do Trabalho Escravo/CONAETE). 


\section{RESUMO}

CRUZ, Thainá Mamede Couto da. A Litigância Estratégica como instrumento de combate ao Trabalho Escravo. Rio de Janeiro: 2018: 106p. Monografia de final de curso. Departamento de Direito da Pontifícia Universidade Católica do Rio de Janeiro - PUC-Rio.

O presente trabalho acadêmico tem como escopo principal examinar o instrumento da litigância estratégica a partir da perspectiva do Sistema Interamericano de Direitos Humanos. Buscou-se, em particular, analisar o ativismo jurídico estratégico promovido pelos atores sociais, o alcance na promoção da justiça social e, consequentemente, o impacto dessa mobilização conjunta em ONGs, movimentos sociais, clínicas de direitos humanos, mídia e sociedade civil, dentre outras, com a finalidade de fomentar o que chamamos de esfera pública transnacional. Na primeira parte, são mapeados e desenvolvidos os conceitos e objetivos do litígio de impacto. Na segunda parte, é abordado o funcionamento do Sistema Interamericano de Proteção de Direitos Humanos em seu conjunto, o âmbito normativo e os órgãos que a compõe, com o objetivo de solidificar a atuação do litígio estratégico no âmbito do Sistema Interamericano. E, finalmente, na última parte, é realizado um estudo aprofundado sobre o caso Fazenda Brasil Verde vs. Brasil, expondo as determinações estabelecidas pela Corte Interamericana de Direitos Humanos pela responsabilização do Estado Brasileiro no enfrentamento ao trabalho escravo contemporâneo, com o propósito de verificar a utilização do instrumento da litigância estratégica e seu desfecho.

Palavras-Chaves: Sistema Interamericano de Proteção aos Direitos Humanos; Litigância Estratégica; Trabalho escravo contemporâneo; Justiça Social; Movimentos Sociais; 


\section{SUMÁRIO}

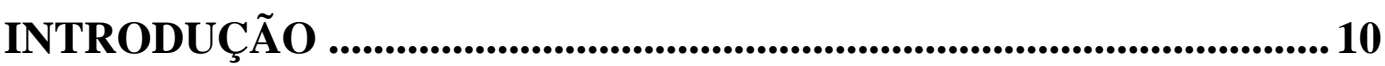

CAPÍTULO 1 - A LITIGÂNCIA ESTRATÉGICA ................................... 13

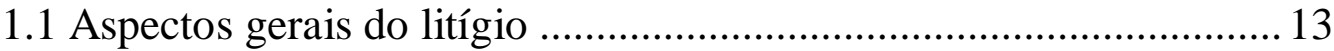

1.2 Definições, características e concepções ............................................. 14

1.3 Litígio estratégico na América Latina ................................................... 20

CAPÍTULO 2 - O SISTEMA INTERAMERICANO DE DIREITOS HUMANOS COMO ARENA PARA O LITÍGIO.....................................25

2.1 Histórico de formação e desenvolvimento do SIDH ............................26

2.2 Âmbito de atuação dos órgãos do Sistema Interamericano .................. 32

2.2.1 Comissão Interamericana de Direitos Humanos.......................... 32

2.2.2 Corte Interamericana de Direitos Humanos ............................... 36

2.3 Do litígio estratégico no Sistema Interamericano ............................... 40

2.3.1 Atuação dos atores sociais na promoção da Justiça Social........ 41

2.3.2 Das etapas do litígio estratégico no SIDH .................................. 45

CAPÍTULO 3 - O CASO FAZENDA BRASIL VERDE VS. BRASILI51

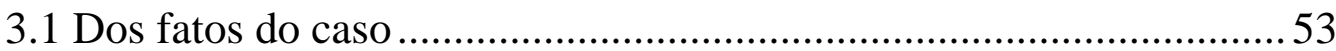

3.2 Comissão Interamericana de Direitos Humanos ................................59

3.3 Corte Interamericana de Direitos Humanos ......................................... 63

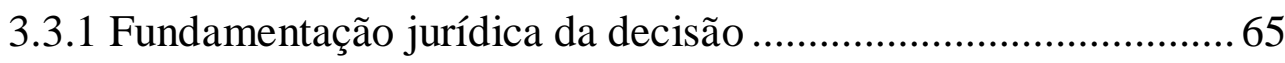

3.3.2 Decisão dos fatos e as reparações ............................................... 71

3.3.3 Repercussões da sentença e seus desafios .................................. 79

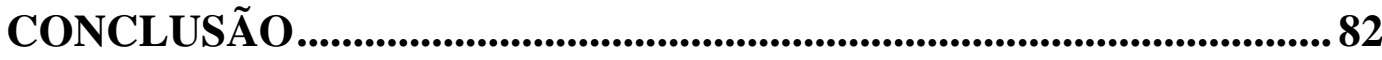

REFERÊNCIAS BIBLIOGRÁFICAS ....................................................86

ANEXO A - ENTREVISTA COM A BEATRIZ AFFONSO (DIRETORA DO CEJIL PARA O PROGRAMA DO BRASIL) 


\section{LISTA DE ABREVIAÇÕES}

CADH - Convenção Americana de Direitos Humanos

CIDH - Comissão Interamericana de Direitos Humanos

Corte IDH - Corte Interamericana de Direitos Humanos

CEJIL - Center for Justice and International Law

CELS - Centro de Estudios Legales y Sociales

CRIN - Child Rights International Network

CPT - Comissão Pastoral da Terra

CDDPH - Conselho de Defesa dos Direitos da Pessoa Humana

DRT - Delegacia Regional do Trabalho

InPACTO - Instituto Pacto Nacional pela Erradicação do Trabalho Escravo

OIT - Organização Internacional do Trabalho

OEA - Organização dos Estados Americanos

ONU - Organização das Nações Unidas

SIDH - Sistema Interamericano de Direitos Humanos

WCL - Washington College Of Law

LRC- The Legal Resources Center

GPTEC/UFRJ - Grupo de Pesquisa Trabalho Escravo Contemporâneo 


\section{LISTA DE ILUSTRAÇÃO}

Figura 1 - Ciclo de vida do Litígio Estratégico no SIDH 
Justiça é um convite oportuno para renunciarmos a disputas políticas e avaliarmos se somos capazes de ter uma discussão sensata sobre que tipo de sociedade realmente queremos viver.

Jonathan Rée 


\section{INTRODUÇÃO}

A partir do século XX, com o final da Segunda Guerra Mundial e as consequentes transformações sociais decorrentes da guerra, o Direito Internacional passou por um processo de transformação e expansão, onde os Estados perceberam a necessidade de proteção dos chamados Direitos Humanos.

Desta forma, o processo de internacionalização vivenciado pelos Estados e a consequente humanização do Direito Internacional são reflexos de uma sociedade que busca não experimentar novamente as atrocidades ocorridas no passado. Com isso, houve uma necessidade de criação de mecanismos internacionais capazes de limitar o poder do Estado e garantir a proteção dos indivíduos, especialmente, no que tange aos seus direitos humanos.

Portanto, de modo a combater as eventuais violações estatais, a sociedade civil pode apresentar denúncia de violações de direitos humanos ao Sistema Interamericano de Direitos Humanos (SIDH), em representação das vítimas, na Comissão Interamericana de Direitos Humanos (CIDH) e posteriormente, o caso pode ser submetido à jurisdição da Corte Interamericana de Direitos Humanos (Corte IDH).

Consequentemente, sendo comprovada tal violação, os Estados serão responsabilizados internacionalmente pelos compromissos violados, devendo reparar os danos causados às vítimas e/ou até mesmo sofrer sanções internacionalmente.

Nesse contexto, percebeu-se a necessidade de avaliar a ferramenta utilizada pelos atores sociais dentro do Sistema Internacional, objetivando pressionar os Estados a internalizar os direitos previstos nas normas. Quanto a tal aspecto, o Estado sendo parte de um Sistema de Proteção de Direitos Humanos deve aceitar e empregar os preceitos internacionais. 
Com efeito, a ferramenta utilizada para a promoção da justiça social é conhecida como litígio estratégico, na qual corresponde a utilização do espaço judicial como arena de deliberação política - neste caso o SIDH-, a fim de oportunizar o debate público acerca de tema atrelado a direitos humanos. Dentro desse contexto, o objetivo desse estudo é impacto alcançado quando há mobilização da sociedade civil, formando pressões de âmbito doméstico e internacional, na construção de uma esfera pública transnacional, especificadamente na erradicação do trabalho escravo contemporâneo.

Em busca de preencher o objeto do trabalho de forma mais complexa, adotaremos como método de pesquisa um apanhado bibliográfico sobre litigância estratégia e o sistema interamericano de direitos humanos e, finalizaremos analisando as considerações adotadas pela Corte Interamericana de Direitos Humanos no caso da Fazenda Brasil Verde. Dessa maneira, o método adotado é um estudo de caso, por meio de pesquisa bibliográfica e documental, com consultas a fontes primárias (Declarações, Estatutos, Convenções, Legislação, Portaria, Documentos Jurídico e Decisões Judiciais) e fontes secundárias (livros, artigos e notícias).

No tocante a estrutura, o trabalho está dividido em três capítulos. No primeiro deles apresentaremos como originou o litígio de impacto, os papéis desempenhados, suas definições, características, concepções e seus efeitos na arena transnacional.

O segundo capítulo trata do Sistema Interamericano de Direitos Humanos como arena crucial para veículo da litigância estratégica. Nesse ponto, foi realizado um apanhado histórico e normativo com a intenção de estabelecer as características do Sistema e demonstrar o funcionamento, de uma maneira geral, da CIDH e da Corte IDH. Além disso, abordaremos a atuação o litígio estratégico no âmbito do SIDH.

Por fim, no terceiro capítulo, descreveremos os fatos do Caso Fazenda Brasil Verde de forma resumida e analisaremos a decisão da Corte 
Interamericana de Direitos Humanos pela responsabilização do Estado Brasileiro no enfrentamento ao trabalho escravo contemporâneo. A intenção deste capítulo é demonstrar a relação das ONGs, sociedade civil, mídia e movimentos sociais na erradicação do trabalho escravo contemporâneo.

É necessário enfatizar que o Brasil é signatário da Convenção Americana de Direitos Humanos, bem como das Convenções n. ${ }^{\circ} 29$ e 105 da OIT que visam proteger os trabalhadores dos Estados signatários de qualquer tipo de trabalho que reduzam o ser humano a condição análoga à de escravo. Assim, resta evidente a relevância dessa temática no Direito Internacional.

Por fim, saliento que esse assunto começou a ser rediscutido no Brasil no final de 2016, com a publicação da sentença da Corte Interamericana, impulsionado pelas tentativas de mudança na definição legal do crime análogo ao escravo pelo Ministério do Trabalho por meio da edição da Portaria MTB n. 1.129, a qual teve seus efeitos suspensos pelo Supremo Tribunal Federal (STF) e, posteriormente, na edição de uma nova Portaria MTB n. 1293, de 28 de Dezembro de 2017 que substituiu a anterior, por violar a Constituição e acordos internacionais celebrados pelo Brasil. 


\section{CAPÍTULO 1 - A LITIGÂNCIA ESTRATÉGICA}

\subsection{Aspectos gerais do litígio}

O chamado litígio estratégico é utilizado para que a escolha de um caso relevante em que possua provas robusta, grande impacto na sociedade, possibilidade de modificação da realidade de milhares de pessoas. O objetivo dessa construção de um discurso-prática não se limita à solução do caso concreto, como a reparação da vítima, mas sim um direito de interesse público que alcança toda uma coletividade, para uma mudança social ${ }^{1}$.

Trata-se de um trecho retirado da obra de Evorah Cardoso sobre o litígio estratégico, pelo qual, destaco como primeira afirmação deste tópico, o papel do direito como instrumento de mudança social, devendo o mesmo acompanhar as pretensões e os interesses da sociedade.

Vale mencionar que o papel do direito como instrumento de mudança social repousa sobre um pressuposto fundamental referente à sua autonomia com a política: os tomadores de decisão são, até certa medida, limitados por essas normas legais criadas pelas políticas ${ }^{2}$. No entanto, essa autonomia judicial pode ser reformulada com a instigação dos advogados na esfera pública. Nesse contexto, desenvolve-se o conceito de litígio estratégico como instrumento de transformação social.

É relevante elucidar que a litigância estratégica consiste em um mecanismo chave no sistema moderno de justiça, de modo que os resultados alcançados trazem visibilidade e fomenta a discussão entre os órgãos do Estado, representantes políticos e sociedade civil, com o propósito de garantia dos direitos humanos.

\footnotetext{
${ }^{1}$ CARDOSO, Evorah Lusci Costa. Litígio Estratégico e o Sistema Interamericano de Direitos Humanos. Belo Horizonte: Editora Fórum, 2012. p. 41.

${ }^{2}$ No original: The role of law as an instrument of social change rests on a fundamental assumption about its relative autonomy from politics: decision makers are to some extent bound by legal rules irrespective of their political consequences.

CUMMINGS, Scott L; RHODE, Deborah. Public Interest Litigation: Insights from Theory and Practice In: Fordham Urban Law Journal, v. XXXVI, UCLA School of Law, 2009. p. 606. Disponível em: <https://papers.ssrn.com/sol3/papers.cfm?abstract_id=1425097〉. Acesso em: 05 jan. 2018.
} 
Portanto, movimentações estratégicas de plano público alcançam reconhecimento dos casos emblemáticos, permitem fixar posições, romper paradigmas e alcançam soluções para o grupo social que se encontra numa situação de vulnerabilidade ${ }^{3}$.

Segundo Villarreal, litigar é uma das atividades que mais identificam o advogado. Fazer com inteligência, cuidado e audácia é o que diferencia o advogado comum de um bom litigante e, para se tornar um "litigante estratégico" é necessário lutar para o desenvolvimento do interesse público, visando contribuir para a mudança social ${ }^{4}$. Contudo, o litígio estratégico não é realizado somente por advogados como também é executado por organizações, instituições acadêmicas, associações de advogados, clínicas de direitos humanos, professores dentre outros.

Desta forma, este capítulo abordará a análise do instrumento da litigância estratégica e sua influência no Direito Internacional dos Direitos Humanos. Primeiramente, iniciaremos com as diferentes definições da litigância estratégica, em seguida suas características, concepções e finalidades. Logo após, perpassaremos sobre sua atuação na América Latina, de modo que possamos compreender a ferramenta na arena do Sistema Interamericano, na qual será trabalhado no segundo capítulo deste trabalho.

\subsection{Definições, características e concepções}

É de primordial importância abordar aqui a existência de vários termos $\operatorname{correlatos}^{5}$ ao litígio estratégico, expressões como "litígio de

\footnotetext{
${ }^{3}$ CORAL-DÍAZ, Ana Milena et al.. El concepto de Litigio Estratégico en América Latina. 19902010., Botogá (Colômbia): Vniversitas, n. 121, julio/diciembre, 2010, p. 52. Disponível em: <http://revistas.javeriana.edu.co/index.php/vnijuri/article/view/14413>. Acesso em: 03 mar. 2018. ${ }^{4}$ VILLARREAL, Marta. El litigio estratégico como herramienta del Derecho de Interés Público In: MATUS, Fabián Sanchez. El litigio estratégico em México: la aplicación de los derechos humanos a nível práctico, experiencias de la sociedade civil. México: Alto Comissionado de las Naciones Unidas, 2007. p. 18. Disponível em:

<https://www.hchr.org.mx/images/doc_pub/litigioestrategico.pdf>. Acesso em: 05 mar. 2018.

${ }^{5}$ Strategic litigation is but one of a number of terms used to refer to the type of activity described. Terms such as "impact litigation" and "test litigation" are sometimes used interchangeably with strategic litigation.
} 
impacto", "litígio paradigmático", litígio de caso-teste", "advocacia de impacto", "litígio de interesse público", "litígio das causas justas" e litígio de prueba"67. À vista disso, afirma Evorah Cardoso:

Não há um conceito definido sobre o que é o litígio estratégico, por isso designálo como um "discurso prática". É possível sistematizar as experiências de litígio estratégico a partir do relato das próprias entidades que o praticam e promovem ${ }^{8}$.

Neste ínterim, Sandra Carvalho e Eduardo Baker relatam que uma possível definição de litígio estratégico encontra-se no Litigation Report da Justice Initiative, um braço da organização de fomento Open Society Foundations que foca seu incentivo especificadamente na área de litígio estratégico. Segundo o documento: "O litígio estratégico em direitos humanos busca por meio do uso da autoridade da lei, promover mudanças sociais em prol dos indivíduos cujas vozes não seriam ouvidas". Nos Estados Unidos da América, também é utilizado o termo high impact litigation ou public interest litigation ${ }^{9}$.

Em um livro editado pela Colombia Law School expõe o que seria esse termo:

Primeiro, o litígio de interesse público persuade o sistema de justiça a interpretar a lei; o litígio de interesse público clama às cortes para que concretizem ou redefinam direitos previstos em constituições, estatutos e tratados para melhor tratar de ilícitos do governo e sociedade e ajudar aqueles que sofreram com eles. Ademais, o litígio de interesse público influencia as cortes para aplicar leis e regras favoráveis existentes, mas, de outra forma, subutilizadas ou ignoradas ${ }^{10}$.

INTERNATIONAL HUMAN RIGHTS LAW GROUP - IHRLG. Promoting Justice: A Practical Guide to Strategic Human Rights Lawyering. Washington: International Human Right Group, 2001. p. 82. Disponível em: <http://www.sbdp.org.br/arquivos/material/280_IHRLG__International_Human_Rights_Law_Group_-_Promoting_justice__a_pratical_guide_to_strategic_HR_lawyering.pdf >. Acesso em: 10 mai. 2018.

${ }^{6}$ CARSOSO, 2012, p. 42.

${ }^{7}$ VILLARREAL, 2007. p. 18.

${ }^{8}$ CARDOSO, op. cit., p. 56.

${ }^{9}$ REKOSH, Edwin et al.. Pursuing the public interest: a handbook for legal professionals and activits. New York: Columbia Law School, 2001 apud CARVALHO, Sandra; BAKER, Eduardo. Experiência de litígio estratégico no Sistema Interamericano de Proteção dos Direitos Humanos. In: Revista SUR, v. 11, n. 20, jun/2014. p. 467. Disponível em: <https://bdjur.stj.jus.br/jspui/handle/2011/90747>. Acesso em: 04 abr. 2018.

10 CARVALHO, Sandra; BAKER, Eduardo. Experiência de litígio estratégico no Sistema Interamericano de Proteção dos Direitos Humanos. In: Revista SUR, v. 11, n. 20, jun/2014. p. 467. Disponível em: <https://bdjur.stj.jus.br/jspui/handle/2011/90747>. Acesso em: 04 abr. 2018. 
Assim, considerando que não há um conceito definido, trago diferentes pontuações do que seria o litígio estratégico na visão de diferentes atores do sistema. Dou início com a definição proposta pela Washington College Of Law (WCL) afirmando que o litígio de impacto se define como uma estratégia de selecionar e promover o litígio de certos casos que resultem em algum efeito significativo nas políticas públicas, na legislação e na sociedade civil de um Estado ou região. Ao mesmo tempo, o litígio de impacto promove o império do direito, provê as bases de futuros casos, facilita a documentação com as violações de direitos humanos, promove a responsabilidade do Governo e contribui para educação e consciência social ${ }^{11}$.

Outrossim, Montoya disserta sobre o litígio de impacto como:

Uma maneira alternativa de instruir e exercer o direito, consistente na estratégia de seleção, análise e início do litígio de certos casos que permitem alcançar um efeito significativo nas políticas públicas, na legislação e a sociedade civil de um Estado ou região. Portanto, é um processo de identificação, socialização, discussão e estruturação de problemas sociais, dos quais é viável promover casos concretos para alcançar mudanças sociais ${ }^{12}$.

De acordo com o Mental Disability Advocacy Centre, o litígio estratégico significa:

Levar os casos ao Tribunal. O litígio estratégico é um método que pode trazer mudanças significativas na lei, na prática ou na conscientização pública, por meio de casos cuidadosamente selecionados para julgamento. Os clientes envolvidos em litígios estratégicos que foram vítimas de violações sofridas por muitas outras pessoas. Desta forma, o litígio estratégico se concentra em um caso individual, a fim de provocar uma mudança social ${ }^{13}$.

\footnotetext{
${ }^{11}$ WASHINGTON COLLEGE OF LAW (WCL). Proyecto del litigio. Washington, 2007. apud MONTOYA, Lucas Correa. Litigio de alto impacto: Estrategias alternativas para enseñar y ejercer el Derecho. Opin. Jurid, v. 7, n. 14, p. 151. Julio-Diciembre de 2008. Universid de Medellín. Disponível em: <https://revistas.udem.edu.co/index.php/opinion/article/view/161/145> Acesso em: 04 fev. 2018.

${ }^{12}$ MONTOYA, Lucas Correa. Litigio de alto impacto: Estrategias alternativas para enseñar y ejercer el Derecho. Opin. Jurid, v. 7, n. 14, p. 160. Julio-Diciembre de 2008. Universid de Medellín. Disponível em: 〈https://revistas.udem.edu.co/index.php/opinion/article/view/161/145> Acesso em: 04 fev. 2018.

${ }^{13}$ No original: Litigation means taking cases to court. Strategic litigation is a method that can bring about significant changes in the law, practice or public awareness via taking carefully-
} 
Destarte, constata-se que o litígio de impacto busca por meio do uso do judiciário e de casos paradigmáticos, alcançar mudanças sociais. Os casos escolhidos são como ferramentas para transformação da jurisprudência dos tribunais e formação de precedentes, para provocar mudanças legislativas ou de políticas públicas. Trata-se de um método, uma técnica que pode ser utilizada para diferentes fins/temas ${ }^{14}$.

No entanto, consoante o entendimento do Child Rights International Network, o litígio estratégico é muito mais do que simplesmente declarar seu caso perante um juiz, envolve a seleção e a apresentação de um caso ao tribunal, visando a criação de mudanças mais amplas na sociedade. As pessoas que utilizam os litígios estratégicos, querem usar a lei para deixar uma marca duradoura, e não somente ganhar o assunto em questão. Isso significa que os casos de litígio estratégico preocupam-se tanto com os efeitos que terão sobre a população e o governo do que exatamente com o resultado final dos próprios casos ${ }^{15}$.

Segundo Diego Morales, diretor do Centro de Estudios Legales y Sociales (CELS), o litígio estratégico pode servir para vários objetivos, em primeiro lugar, para desenvolver e expor padrões de condutas estruturais, ilegais e sistemáticas que violam os direitos humanos, em segundo lugar para promover os direitos não garantidos daquele grupo específico e, em terceiro lugar, questionar as políticas públicas que contradiz o entendimento internacional qual seja seu conteúdo e forma de atuação e, por fim, incluir na agenda de discussões do poder essas novas necessidades dos direitos humanos ${ }^{16}$.

selected cases to court. The clients involved in strategic litigation have been victims of [wrongs] that are suffered by many other people. In this way, strategic litigation focuses on an individual case in order to bring about social change.

MENTAL DISABILITY ADVOCACY CENTRE. Disponível em: <http://mdac.org/en/what-wedo/strategic_litigation>. Acesso em: 01 jun. 2018.

${ }^{14}$ CARSOSO, 2012, p. 41.

15 CHILD RIGHTS INTERNATIONAL NETWORK (CRIN). Disponível em: <https://www.crin.org/en/guides/legal/guide-strategic-litigation/what-strategic-litigation>. Acesso em: 01 jun. 2018.

${ }^{16}$ CELS. Litigio estratégico y derechos humanos: La lucha por el derecho. $1^{\mathrm{a}}$ ed. Buenos Aires: Siglo Vienteuno Editores, 2008. p. 17. Disponível em: 
É possível perceber que o litígio estratégico não ocorre somente no âmbito no sistema internacional, haja vista que essa estratégia judicial também pode ser utilizada no sistema interno de cada país. As estratégicas de litígio podem variar de maneira ampla e um número significativo de advogados de direitos humanos está usando o litígio de impacto como estratégia de mudança social por meios legais.

Para fins de conceituação, a strategic litigation é a utilização do espaço judicial como arena de deliberação política, a fim de oportunizar o debate público acerca de algum tema constitucional atrelado a direitos fundamentais, que não tenha recebido o devido tratamento no Executivo ou Legislativo; podendo ser considerada bem-sucedida quando, ainda que a pretensão não seja acolhida pelo Judiciário, o assunto venha a produzir algum tipo de impacto na sociedade ${ }^{17}$.

Sabe-se que, uma das características principais do litígio estratégico é ser um processo completo de intervenção social diferentemente da atuação litigiosa tradicional, apesar dos meios jurídicos utilizados serem os mesmos. A diferença fundamental que se distingue é a própria estratégia da ação, tendo em vista que o litígio de impacto não se restringe unicamente aos meios processualmente jurídicos, ele busca tematizar o objeto e promover um mecanismo dialógico de devolução do debate à sociedade gerando efeitos no meio políticos, sociais, psicológicos, educativos entre outros.

Com relação a finalidade, o litígio de alto impacto também se diferencia do litígio tradicional, uma vez que o primeiro corresponde a uma advocacia issue-oriented ou policy-oriented ${ }^{18}$, enquanto que, o segundo

<https://www.idl.org.pe/sites/default/files/publicaciones/pdfs/GuiaIDL.pdf>. Acesso em: 04 abr. 2018.

${ }^{17}$ LEVY, Leonard W. et al.. Encyclopedia of the American Constitution. New York: Macmilian Publishing Company, 2000. p. 231-237 apud MANEIRO, Renata de Marins Jaber; PULCINELLI, Eliana. Litígio estratégico, vinculação de precedentes e abertura ao diálogo constitucional do provimento jurisdicional In: Revista de Investigações Constitucionais, Curitiba, v. 4, n. 2, p. 194195, maio/ago.2017. Disponível em: <revistas.ufpr.br/rinc/issue/download/2378/414>. Acesso em: 10 mai. 2018.

${ }^{18}$ By contrast, policy-oriented organizations have more scope to be strategic both in conducting litigation and choosing goals and means for litigation. Other policy-oriented organizations such 
trabalha com uma advocacia client-oriented ${ }^{1920}$. A primeira busca o impacto social que o caso pode trazer para além das partes no litígio por meio da técnica estratégica na defesa do interesse público, dos direitos fundamentais, sociais, econômicos e culturais, assim como os direitos coletivos, ao passo que o segundo atende às demandas e interesses do cliente. Antes de prosseguir com a análise do litígio estratégico, é preciso informar que as entidades de advocacia client- oriented também podem exercer o litígio estratégico, mas geralmente de maneira ad hoc, devido às circunstâncias do caso concreto ${ }^{21}$.

Uma vez explorada a origem e o desenvolvimento do litígio estratégico e compreendida a ligação do discurso-prática com os atores sociais, as autoras Ana Díaz, Beatriz Londoño e Lina Muñoz apresentam quatros diferentes pontos de $v^{2}$ sta $^{22}$, isto é, classificações do litígio estratégico em direitos humanos, pelos quais baseiam-se numa adaptação regional do conceito anglo-saxão de impact litigation, utilizando como delimitadores o objeto e as ferramentas utilizadas por cada litigante.

as Amnesty International use means other than litigation to bring about social change. There may be greater distance between such organizations and the constituency they represent than in the case of client-orient organizations. Often, such organizations must locate and 'recruit' clients (if this is permissible under local laws or practices) to advance a particular programmatic objective or issue. As the objective of the case is not determined solely by the client's needs, this kind of approach necessarily involves a much greater degree of debate about values and priorities (often involving consultations with the constituent community) and strategic planning.

ERRC, INTERIGHTS, MPG, Strategic Litigation of race discrimination in Europe: from principles to practice, 2004. p. 41. Disponível em:

<http://www.errc.org/uploads/upload_en/file/00/C5/m000000C5.pdf>. Acesso em: 15 abr. 2018.

${ }^{19}$ Client-oriented organizations focus on helping individuals without regard to the impact of a case on national policy. They concentrate mostly on representing clients in the office's area of specialization. This may be a single issue, such as housing or immigration, a single minority group, such as indigenous group, or an underrepresented locality. The majority of such organizations are community based and close to the populations they represent. This model results from the needs of a group or locality, available resources, or the objectives and philosophy of the organization. Where such organization decides to undertake litigation with 'strategic' effects, its choices of cases are more determined by constituency needs than potential impact.

Ibid., p. 40-41.

${ }^{20}$ CARDOSO, 2012, p. 42.

21 Although it [organization client-oriented] may not choose the case with a view to strategic impact, organizations when confronted with a good set of facts often approach the case in a strategic way. Because of strong community ties, such organizations often have better community support, input, and understanding than policy-oriented organizations. Client-oriented organizations also often benefit from a greater flow of information from problems centres. This makes framing of goals much easier and also makes it easier to prepare cases.

Ibid., p-40-41.

${ }^{22}$ CORAL-DÍAZ, 2010, p. 53-54. 
Note-se, assim, as quatros diferentes perspectivas explanadas: (i) concepções centradas na defesa judicial dos direitos humanos e do interesse público, por meio de ferramentas judiciais ${ }^{23}$; (ii) concepções centradas nos resultados de alto impacto de mudanças estruturais, se utilizando para tal de ferramentas políticas, jurídicas e sociais; (iii) concepções centradas no momento da intervenção/ação, isto é, litígio estratégico preventivo, buscando evitar danos ou prejuízos aos direitos humanos ou ao interesse público ou litígio estratégico corretivo, quando objetivam a reparação de uma ação cujo resultado produzido foi negativo aos direitos humanos ou ao próprio interesse público e por fim, (iv) concepções centradas nos direitos humanos daquelas pessoas que necessitam de proteções especiais, como, por exemplo, pessoas com deficiências, idosos, povos indígenas, mulheres e entre outros.

Dessa forma, é possível aferir que apesar do direcionamento da demanda ser diferente, o objetivo primordial da ação é a garantia dos direitos inerentes ao homem e/ou a reparação de uma violação que produziu efeitos negativos aquela pessoa ou grupo.

\subsection{Litígio estratégico na América Latina}

Neste tópico veremos como o litígio estratégico está intimamente ligado à educação jurídica e ao surgimento das chamadas "clínicas" de direitos humanos na Europa, nos Estados Unidos da América e em alguns países da América Latina como Chile, Argentina e Colômbia ${ }^{24}$.

Evorah Cardoso afirma que a origem do litigio estratégico está estritamente relacionada aos atores que a praticam e propagam, por isso denominada de discurso prática, tendo em vista que as ONGs foram as geradoras e impulsionadoras dessa concepção na América Latina. Podemos

\footnotetext{
${ }^{23}$ Nesta primeira concepção, as autoras referem a definição dada por Raquel Yrigoyen: (...) Em esta primeira concepción de litigio estratégico se enmarca la definición aportada por Raquel Yrigoyen: Em litigio estratégico em derechos humanos es parte de ejercicio del derecho de acceso a la justicia, y tiene como objetivo final el cumplimiento efectivo de los derechos humanos, ordenado por instancias de justicia nacionales o internacionales.

${ }^{24}$ CARVALHO; BAKER, 2014, p. 466-467.
} 
citar como pioneiras a $\operatorname{CELS}^{25}$ na Argentina, ILSA na Colômbia e a Comissão Andina de Jurista do Peru.

Em decorrência do cenário regional, essas ONGs utilizaram dessa técnica como um dos seus principais instrumentos, entendendo como oportuno a promoção dos graves casos de violações de direitos humanos, em oposição às impunidades cometidas pela jurisdição interna de cada país. Contudo, o próprio termo de litigância sofreu uma evolução dividida em duas etapas, haja vista a mudança de cenário do regime político da maioria dos países latino-americanos.

Ana Díaz, Beatriz Londono e Lina Marcela Ávila concluem que a primeira se enquadra nas denúncias de violação de direitos humanos nos regimes autoritários na América Latina, especialmente a Comissão Interamericana de Direitos Humanos (CIDH) que produzia relatório sobre a situação sobre as violações perpetradas nos países da região. Pode-se dizer que as ONGs e ativistas conseguiram iniciar uma pressão sobre os seus governos, mobilizando de tal forma pontos e questões, na qual o objetivo era de publicização para o fim dessa política violadora, transformando a realidade do regime autoritário para democrático.

A segunda etapa ocorreu com a mudança do cenário político a partir das décadas de 80 e 90 com a transformação institucional do ambiente doméstico e a internacionalização ${ }^{26}$, ao invés desses atores sociais lutarem contra aquela repressão estatal, passaram a combater a falta de responsabilidade estatal a partir das próprias instituições democráticas. Além disso, nesse contexto de democratização e internacionalização, os atores sociais ao recorrerem aos fóruns internacionais, começaram a trabalhar com a construção de um processo normativo transnacional que não se esgota apenas com as decisões adotadas nesses espaços domésticos.

\footnotetext{
${ }^{25}$ Para mais informações: CELS, Litígio estratégico y derechos humanos. La lucha por derecho. Disponível em: <http://www.cels.org.ar/common/documentos/la_lucha.pdf> Acesso em: 04 abr. 2018.

${ }^{26}$ O objetivo era de complementar e melhorar o ambiente doméstico interno do país, de modo que ajudasse no processo de reconhecimento de um direito não admitido, visando a transformação das políticas domésticas.
} 
Cardoso informa que essa geração que trabalha na construção de um processo normativo transnacional é composta, de modo geral, por ONGs profissionais, "clínicas jurídicas" ligadas às universidades, centros de advocacia pro bono, com enfoque policy-oriented ${ }^{27}$. Além disso, relevo a recente atuação da Defensoria Pública nas atuações estratégicas, bem como inúmeros fóruns de debate sobre a aplicação desse método ${ }^{28}$.

No terceiro capítulo desse trabalho, analisaremos uma sentença da Corte Interamericana de Direitos Humanas tratando sobre trabalho escravo e tráfico de pessoas. Por oportuno, apresento a Clínica de Trabalho Escravo e Tráfico de Pessoas da Faculdade de Direito da UFMG que faz parte de uma experiência pioneira na temática de trabalho escravo na formação de um sistema internacional de Clínicas de Direito ${ }^{29}$.

Em suma, segundo as autoras Maneiro e Pulcinelli, o litígio estratégico interno é a prática que objetiva veicular temas constitucionais que não tenham recebido o devido tratamento pelo poder público, e que, por

\footnotetext{
${ }^{27}$ CARSOSO, 2012, p. 54.

${ }^{28}$ MACHADO, Isabel Penido de Campos. Defensores Públicos Interamericanos: novos horizontes de acesso à justiça. Disponível em: <http://www.dpu.def.br/images/esdpu/jornaldpu/edicao_8/forum-8-edicao.pdf $>$. Acesso em: 02 mai. 2018. e ESCOLA SUPERIOR DA DEFENSORIA PÚBLICA DA UNIÃO, Litigância Estratégica. 2018, 12p. Disponível em:

<http://www.dpu.def.br/images/esdpu/jornaldpu/edicao_12/informativo_ESCOLA_ed12_ano4._D efinitivo.pdf>; CASOTECA DE LITIGÂNCIA ESTRATÉGICA EM DIREITOS HUMANOS. <http://casoteca.forumjustica.com.br/> Acesso em: 02 mai. 2018.

${ }^{29}$ CLÍNICA DE TRAB ALHO ESCRAVO DA UFMG. Entrevista concedida a Thainá Mamede. 24 mai. 2018. A ideia surgiu com expansão do modelo de clínica da Universidade de Michigan para o Instituto Tecnológico Autónomo de México, na Cidade do México. Em seguida, foi criado o Clinnect HTS, com uma iniciativa para estabelecer uma rede global de clínicas de Direito especializadas em tráfico de pessoas e trabalho escravo para intercâmbio das melhores práticas. As clínicas de Direito que integram o Clinnect HTS oferecem aos estudantes oportunidades de trabalho tanto em âmbito doméstico quanto internacional, em questões que envolvem tráfico de pessoas e trabalho escravo. A inserção da Faculdade de Direito da UFMG no Clinnect HTS permite a formação de laços em caráter internacional e representa marcante oportunidade de intercâmbio aos alunos que passarão a integrar o presente projeto. O nascimento da CTETP vem, justamente, de uma necessidade identificada em prover assistência judiciária gratuita e qualidade para pessoas vítimas desses dois crimes. Nesse sentido, eles fazem o acompanhamento dos casos de maneira integral. Por fim, a Clínica informou que ela é dividida em três linhas: ensino, pesquisa e extensão. Nossa principal atuação é com o serviço de assistência judiciária gratuita e acompanhamento de casos. No foco do ensino, temos uma disciplina optativa semanal que versa, na Universidade, sobre temas relativos ao tráfico de pessoas e trabalho escravo. Destacou que a metodologia é diferenciada, havendo inúmeras aulas práticas que buscam treinar o aluno a realizar um atendimento, conversar com um assistido, fazer entrevistas, redigir peças processuais, entre outras habilidades. Realizam diversos tipos de eventos, campanhas de mídia, bem como dão aulas em escolas municipais sobre conscientização contra os crimes de trabalho escravo e tráfico de pessoas.
} 
envolver uma tática de transformação da realidade social, possui ponto de contato com a vinculação de precedentes. Por isso que é muito conhecida na experiência de países de tradição da common law; embora seja possível identificar que essa estratégia está começando a ser utilizada no Brasil ${ }^{30}$.

Cardoso afirma que o litígio estratégico é um desdobramento do movimento do "direito do interesse público" que está historicamente relacionado ao acesso à justiça por pessoas marginalizadas política ou economicamente. O "direito do interesse público" desenvolveu-se, principalmente nos EUA, a partir da década de 60, onde serviu principalmente aos movimentos pelos direitos civis ${ }^{31}$. Além disso, afirma que talvez tenha sido nos EUA que o judiciário foi mais utilizado como ferramenta de transformação social.

Muitos advogados dos países da common law enfatizam a importância dos precedentes para promoção dos direitos humanos. Por exemplo, atualmente, The Legal Resources Center (LRC) da África do Sul, concentra sua estratégia de litígios de impacto em questões socioeconômicas, dado o novo e maior reconhecimento de tais direitos na Constituição sul-africana pós-apartheid ${ }^{32}$.

Enquanto que, nos países civil-law, onde os precedentes não têm tanto valor no sistema de lei como nos países da commow law, os litigantes entendem que a determinação judicial ajuda na possibilidade de moldar as decisões dos juízes.

Consequentemente, podemos concluir que tanto nos países que pertencem a tradição jurídica da common law como nos países com tradição jurídica romano-germânica, os atores sociais, tais como clínicas de direitos,

\footnotetext{
${ }^{30}$ MANEIRO, Renata de Marins Jaber; PULCINELLI, Eliana. Litígio estratégico, vinculação de precedentes e abertura ao diálogo constitucional do provimento jurisdicional In: Revista de Investigações Constitucionais, Curitiba, v. 4, n. 2, p. 194, maio/ago.2017. Disponível em: <revistas.ufpr.br/rinc/issue/download/2378/414>. Acesso em: 10 mai. 2018.

${ }^{31}$ CARSOSO, 2012, p. 43.

${ }^{32}$ WILSON, Richard J. RASMUSEN, Jennifer. Promoting Justice: A Practical Guide to Strategic Human Rights Lawyering. International Human Rights Law Group, 2001. p. 60. Disponível em: <http://pdf.usaid.gov/pdf_docs/Pnadf477.pdf>. Acesso em: 30 mai. 2018.
} 
defensores interamericanos, ONGs e outros grupos têm utilizado dessa técnica.

Com base nos pontos mencionados, é plausível pensar que os objetivos do litígio estratégico envolvem mais do que simplesmente ganhar argumentos jurídicos nos tribunais e sim tentar conscientizar e divulgar a causa, de modo que mobilize, promova debate público, estabeleça precedentes importantes e altere a realidade daquelas pessoas que se encontram nas mesmas condições e fomente mudanças políticas ${ }^{33}$.

Isto posto, é necessário transitar pelo funcionamento dos órgãos que compõem o Sistema Interamericano de Direitos Humanos, de modo que se tenha compreensão dessa arena internacional na utilização de mecanismos para garantia de direitos humanos.

\footnotetext{
${ }^{33}$ No original: The aims of strategic litigation involve more than simply winning legal arguments in court: test case strategies might seek to create awareness and publicise the cause for which the strategy is mobilised, encourage public debate, set important precedents, achieve change for people in similar situations, and spark policy changes.

WILSON; J. RASMUSEN, 2001, p. 7.
} 


\section{CAPÍTULO 2 - O SISTEMA INTERAMERICANO DE DIREITOS HUMANOS COMO ARENA PARA O LITÍGIO}

A internalização dos direitos humanos surgiu após as enormes atrocidades e barbáries ocorridas durante a Segunda Guerra Mundial (1939 -1945). Nota-se, pois, que houve uma necessidade de criação de mecanismos internacionais capazes de limitar o poder do Estado e garantir a proteção dos indivíduos, especialmente, no que tange aos seus direitos fundamentais. Nesse contexto, o processo de internacionalização ${ }^{34}$ dos direitos humanos e a consequente humanização do Direito Internacional são os reflexos de uma sociedade que busca não experimentar tais violações novamente ${ }^{35}$.

Por oportuno, verdade é que esse processo somente foi possível mediante ao rompimento da noção de que o Estado é o único sujeito de Direito Internacional e com soberania absoluta. A conjectura e o precedente que mudou esse pensamento foi o Direito Humanitário, a Organização Internacional do Trabalho e a Liga das Nações.

Em 1945, pós $2^{\mathrm{a}}$ Guerra Mundial, foi criada a Organização das Nações Unidas (doravante ONU) com os seus principais objetivos: (i) manutenção da paz e segurança internacional; (ii) promoção dos direitos humanos no âmbito internacional e; (iii) cooperação internacional nas esferas social e econômica.

\footnotetext{
${ }^{34}$ A partir de 1945 , com o processo de internacionalização dos direitos humanos, houve uma drástica mudança de suas referências normativas, por meio de uma série de acontecimentos históricos como a criação da ONU (1945), cuja carta afirmava expressamente os direitos humanos como objetivo central da instituição; a promulgação da Declaração Universal de Direitos Humanos (1948); a atuação dos tribunais internacionais de Tóquio e Nuremberg (1945-46) que introduziram novidades jurídicas como a figura do crime contra a humanidade; a promulgação da Convenção sobre a Prevenção e Sanção do Crime de Genocídio (1948); a sistematização do direito humanitário por meio da Convenção de Genebra (1948), dentre outros.

GOMEZ, José Maria. Globalização dos direitos humanos, legado das ditaduras militares no Cone Sul latino-americano e justiça transicional In: Direito, Estado e Sociedade: Revista do Departamento de Direito da PUC-Rio. Rio de Janeiro, n. 33. p. 88.

${ }^{35}$ PIOVESAN, Flávia. Direitos Humanos e Justiça Internacional. $4^{a}$ ed. São Paulo: Saraiva, 2013. p. 43.
} 
Sendo assim, no tópico a seguir, para melhor compressão das questões tratadas nesse trabalho, serão apresentados os seguintes pontos: o marco normativo do sistema interamericano, sua formação e desenvolvimento e, por último, o funcionamento dos órgãos do Sistema Interamericano.

\subsection{Histórico de formação e desenvolvimento do SIDH}

Impulsionado por esses precedentes pós-guerra, dentro do processo histórico de internacionalização dos direitos humanos, iniciou-se o movimento do Direito Internacional dos Direitos Humanos (DIDH), que, através de diversos tratados internacionais, gerou dois sistemas de proteção do indivíduo: o sistema global e o sistema regional ${ }^{36}$.

O primeiro é formado pelos instrumentos internacionais e órgãos burocráticos conduzidos pela ONU. Em contrapartida, o segundo tem por objetivo internalização dos direitos humanos no plano regional, subdividido em três grandes sistemas, como o Sistema Europeu de 1950, o Americano de 1969 e o Africano de 1981.

Os sistemas regionais complementam o sistema global, tendo em conta que possuem o mesmo objetivo de proteção do indivíduo e o combate às violações de direitos humanos. Isto posto, vige internacionalmente o princípio da primazia da norma mais favorável à vítima - princípio pro persona -, sendo assim, se o indivíduo tiver algum direito violado, ele pode optar pelo sistema que mais lhe beneficie.

Posteriormente a fundação da ONU, também foi instituída a Organização dos Estados Americanos ${ }^{37}$ (doravante OEA), ela foi o organismo regional que estruturou a proteção dos direitos humanos nas Américas, tendo como objetivo alcançar uma ordem de paz e de justiça, para promover sua solidariedade, intensificar sua colaboração e defender

\footnotetext{
${ }^{36}$ PIOVESAN, 2013, p. 45-46.

${ }^{37}$ Durante a IX Conferência Internacional Interamericana de Estados Americanos, realizada em Bogotá em maio de 1948.
} 
sua soberania, sua integridade territorial e sua independência ${ }^{38}$. Concomitantemente, no mesmo ano da criação da OEA, foi aprovada a Declaração Americana de Direitos e Deveres do Homem de 1948 (Declaração Universal de Direitos Humanos em 1948), primeira declaração de direitos humanos aprovada por órgãos internacionais ${ }^{39}$.

A Declaração formou a primeira base normativa de proteção aos direitos humanos de caráter geral no sistema e continua sendo um instrumento de importância e expressão regional, especialmente para os Estados que não são parte da Convenção Americana ${ }^{40}$. A Declaração se destacou de outros instrumentos internacionais de direitos humanos, pois não definiu apenas os direitos, mas os deveres dos cidadãos ${ }^{41}$. No entanto, vale dizer que a declaração não é considerada um tratado internacional, mas fonte de obrigação para os Estados e membros da OEA, conforme Opinião Consultiva da Corte $\mathrm{IDH}^{42}$.

Dez anos depois, em 1969, os Estados Americanos adotaram em São José, Costa Rica, a Convenção Americana de Direitos Humanos (CADH), também conhecida como Pacto de São José, que entrou em vigor somente em 1978, após alcançar o número mínimo de onze ratificações estatais. A Convenção Americana estipulou também a criação da Corte Interamericana de Direitos Humanos (Corte IDH), fundada um ano depois, como um órgão jurisdicional do SIDH, responsável por julgar as violações de direitos humanos perpetradas pelos Estados que ratificaram sua competência.

Dentre os quatros principais instrumentos do SIDH, temos a Carta dos Estados Americanos (1948), a Declaração Americana dos Direitos e

\footnotetext{
${ }^{38}$ Artigo $1^{\circ}$ da Carta da OEA.

${ }^{39}$ SCHETTINI, Andrea Bandeira de Melo; FERREIRA, Natalia Damazio Pinto. Uma introdução ao Sistema Interamericano de proteção dos direitos humanos: reflexões sobre sua história, estrutura e o recente posicionamento do Estado Brasileiro. CONPEDI, 2016, p.153 Disponível em: <https://www.conpedi.org.br/publicacoes/y0ii48h0/va83towp/d8E6kevG2W3HUq56.pdf>. Acesso em: 12 mai. 2018.

${ }^{40}$ MAZZUOLI, Valério de Oliveira. Curso de Direito Internacional Público. $7^{\mathrm{a}}$ ed. São Paulo: Editora Revista dos Tribunais, 2013. p. 926.

41 Declaração Americana dos Direitos e Deveres do Homem, 1948. Disponível em: <https://www.cidh.oas.org/basicos/portugues/b.Declaracao_Americana.htm>. Acesso em: 12 mai. 2018.

42 CORTE IDH. Interpretação da Declaração Americana dos Direitos e Deveres do Homem. Opinião Consultiva OC-10/89, parágrafo 42.
} 
Deveres do Homem (1948); a Convenção Americana sobre Direitos Humanos (1969) - também conhecida como Pacto de Sam José da Costa Rica (1969) e o Protocolo Adicional à Convenção Americana em Matéria de Direitos Econômicos, Sociais e Culturais (1988) - chamado também Protocolo de San Salvador $(1988)^{43}$.

Quanto ao desenvolvimento do sistema interamericano, veremos que SIDH teve sua origem em um ambiente autoritário, cercado por ditaduras, que não permitia qualquer associação direta ou imediata entre democracia, Estado de Direito e direitos humanos. Victor Abramovich ${ }^{44}$ afirma que o desenvolvimento do sistema não foi linear, dividindo-o em quatro fases: $1^{\mathrm{a}}$ fase da década de 1970 a 1980, $2^{\text {a }}$ fase do final da década de 1980 até o início da década de $1990,3^{\mathrm{a}}$ fase nos anos 2000 e por fim, a $4^{\mathrm{a}}$ fase de desafios e crise institucional. Atualmente, o SIDH se encontra num período de fortes debates, tendo em vista o novo cenário político regional de democracias deficitárias e excludentes.

$\mathrm{Na}$ primeira fase, o SIDH desempenhou o papel, ainda que limitado, de crítica e combate às graves violações de direitos humanos perpetrados pelas ditaduras militares instauradas na América Latina ${ }^{45}$. Especificamente no Brasil, a $\mathrm{CIDH}$, recebeu, ao menos, 77 denúncias contra o país, que ocupou, à época, o segundo lugar do continente em número de petições apresentadas. Destas, somente 20 foram aceitas como casos concretos, do quais apenas um não se referia à prática de tortura, desaparecimento forçado, prisão arbitrária e assassinato ${ }^{46}$. Ou seja, o seu papel foi o último

\footnotetext{
${ }^{43}$ MAZZUOLI, 2013, p. 926.

${ }^{44}$ ABRAMOVICH, Victor. Das violações em massa aos padrões estruturais: novos enfoques e clássicas tensões no sistema interamericano de direitos humanos. In: SUR - Revista Internacional de Direitos Humanos. v. 6, no. 11, dez. 2009. p. 8. Disponível em:

<http://www.scielo.br/scielo.php?pid=S1806-64452009000200002\&script=sci_abstract\&tlng=pt $>$. Acesso em: 12 mai. 2018.

${ }^{45}$ SCHETTINI; FERREIRA, 2016, p. 154.

46 SANTOS, Cecília MecDowell. Memória na Justiça: A mobilização dos direitos humanos e a construção da memória da ditadura no Brasil In: Revista Crítica de Ciências Sociais. no. 88, 2010. p. 127-154 apud SCHETTINI, Andrea Bandeira de Melo; FERREIRA, Natalia Damazio Pinto. Uma introdução ao Sistema Interamericano de proteção dos direitos humanos: reflexões sobre sua história, estrutura e o recente posicionamento do Estado Brasileiro. CONPEDI, 2016. p. 154. Disponível em:
} 
recurso de justiça para as vítimas das violações, já que não podiam buscar proteção na jurisdição interna.

A segunda fase foi marcada pela transição de regimes autoritários para sistemas políticos democráticos, na qual o SIDH passou acompanhar toda essa transição de sistema. Nessa perspectiva, o SIDH começou a delinear os princípios fundamentais sobre o direito à justiça, à verdade e à reparação de graves violações, em massa e sistemáticas, de direitos humanos ${ }^{47}$. Exemplo dessa atuação foi a sentença proferida em 1988, no caso Velasquez Rodrigues vs. Honduras ${ }^{48}$, onde a Corte Interamericana responsabilizou o Estado de Honduras pelo desaparecimento forçado do estudante Angel Manfredo Velasquez Rodrigues, determinando o dever estatal de prevenir, investigar, processar, punir e reparar as violações cometidas.

Santos afirma que desde meados dos anos 80, a maior parte dos países na América Latina tem obtido sucesso em pôr fim aos regimes militares autoritários, promovendo direcionamento importantes em direção à democracia. Em seguida, relata que a maioria dos países na região possui agora um regime político democrático, juntamente com uma legislação progressiva que garante novos direitos a grupos frequentemente excluídos, tais como prisioneiros, trabalhadores rurais, criança de rua, população indígena, negros, mulheres, homossexuais, LGBTs. No entanto, práticas sistemáticas de violação de direitos humanos contra esses grupos sociais ainda têm ocorrido na América Latina ${ }^{49}$.

No período da terceira fase, foi o momento de maior estabilidade, na qual, o sistema demarcou o papel subsidiário de proteção dos direitos

<https://www.conpedi.org.br/publicacoes/y0ii48h0/va83towp/d8E6kevG2W3HUq56.pdf >. Acesso em: 12 mai. 2018.

${ }^{47}$ ABRAMOVICH, 2009, p. 9.

${ }^{48}$ Caso Velásquez vs. Honduras. Disponível em:

<http://www.cnj.jus.br/files/conteudo/arquivo/2016/04/2ed9f5488d3b613fb7364d2008a0c3a1.pdf $>$. Acesso em: 12 mai. 2018.

49 SANTOS, Cecília Macdowell. Ativismo jurídico transnacional e o Estado: reflexões sobre os casos apresentados contra o Brasil na Comissão Interamericana de Direitos Humanos In: SUR Revista Internacional de Direitos Humanos. v. 4, $\mathrm{n}^{\circ}$ 7. São Paulo, 2007. p. 33. Disponível em: <http://www.scielo.br/scielo.php?pid=S1806-64452007000200003\&script=sci_abstract\&tlng=pt $>$. Acesso em: 12 mai. 2018. 
humanos à esfera interna dos Estados, preservando a autonomia dos processos políticos internos. Entretanto, colaborando de forma mais específica nas violações de direitos humanos cometidas por cada continente de forma mais estrutural, a título de exemplo, o acesso à justiça, à violência institucional, a independência dos tribunais, entre outros.

Por fim, na quarta fase, o SIDH passou por uma forte crise institucional, onde países como Bolívia, Equador e Venezuela começaram a criticar abertamente o sistema interamericano, especialmente a atuação da Comissão Interamericana, afirmando que seria um órgão tendencioso e alinhado à política norte-americana.

Tal argumentação, colocava a prova a legitimidade do SIDH, haja vista que a sede da Comissão ser localizada em Washington, capital dos Estados Unidos, país que não ratificou a $\mathrm{CADH}$, nem aceitou a jurisdição da Corte IDH; o fato de os principais financiadores da CIDH serem Estados europeus e organismos e fundações de cooperação internacional financiadas por Estados observadores que não ratificaram a $\mathrm{CADH}$; e o fato de supostamente não alcançar as principais demandas e transformações latinoamericanas, mantendo-se limitada a uma visão liberal dos direitos humanos, que, a demais, desrespeitaria a soberania dos Estados ${ }^{50}$.

Certamente, após a denúncia do instrumento normativo pela Venezuela em setembro de 2012, o conflito se expandiu ainda mais, resultando na realização pela Assembleia Geral da OEA de um processo oficial de Reflexão sobre o Funcionamento da Comissão Interamericana de Direitos Humanos para o fortalecimento do Sistema Interamericano de Direitos Humanos ${ }^{51}$.

\footnotetext{
${ }^{50}$ PRONER, Carolina. Sistema Interamericano de Direitos Humanos precisa ser reformado? 2012 apud SCHETTINI, Andrea Bandeira de Melo; FERREIRA, Natalia Damazio Pinto. Uma introdução ao Sistema Interamericano de proteção dos direitos humanos: reflexões sobre sua história, estrutura e o recente posicionamento do Estado Brasileiro. CONPEDI, 2016. p. 156. Disponível em: <https://www.conpedi.org.br/publicacoes/y0ii48h0/va83towp/d8E6kevG2W3HUq56.pdf>. Acesso em: 12 mai. 2018.

${ }^{51}$ OEA. Sobre o fortalecimento. Disponível em:

<http://www.oas.org/pt/cidh/fortalecimento/consulta2013.asp>. Acesso em: 12 mai. 2018.
} 
Embora o Brasil não tenha se pronunciado publicamente sua posição sobre o processo de enfraquecimento do Sistema, um membro da Assessoria Especial da República, Guilherme de Aguiar Patriota, publicou um artigo $^{52}$ sobre o sistema. No mesmo espaço, a professora do Instituto de Relações Internacionais da USP, Deisy Ventura, a professora de Direitos Humanos na PUC-SP, Flávia Piovesan e a diretora de Programas da Conectas, Juana Kweitel publicaram no jornal Folha de S. Paulo o artigo intitulado de Sistema Americano sob forte ataque ${ }^{53}$, na seção Tendências e Debates, analisando o papel do Brasil nesse momento complicado.

Apesar de toda essa questão de legitimidade do SIDH, Abramovich afirma que após a aceitação da competência da Corte Interamericana e a atribuição à Convenção Americana a hierarquia constitucional ou superior às leis ordinárias em seus sistemas jurídicos, os advogados, os juízes, os operadores do direito, os funcionários e ativistas sociais aprenderam muito mais sobre a lógica de funcionamento do SIDH e começaram a utilizá-lo já não mais de maneira excepcional ou seletiva; como também começaram a citar suas decisões e argumentar com seus precedentes nos tribunais locais e em debates sobre políticas públicas. Com isso, a jurisprudência do SIDH começou a ser aplicada gradualmente nas decisões dos tribunais constitucionais e das cortes supremas nacionais e, nos últimos tempos, ainda que de maneira incipiente, na formulação de algumas políticas estatais. Esse processo de incorporação do direito internacional dos direitos humanos no âmbito nacional produziu importantes mudanças institucionais ${ }^{54}$.

52 CONECTAS. Dossiê OEA: Sistema sob ataque, 2012. Disponível em: <http://old.conectas.org/pt/acoes/politica-externa/noticia/dossie-oea〉. Acesso em: 20 mai. 2018. FOLHA DE SÃO PAULO, Guilherme de Aguiar Patriota: Dois pesos, duas medidas. Disponível em: <https://www1.folha.uol.com.br/fsp/opiniao/59211-dois-pesos-duas-medidas.shtml〉. Acesso em: 20 mai. 2018.

${ }^{53}$ FOLHA DE SÃO PAULO, Disponível em: <https://www1.folha.uol.com.br/fsp/opiniao/59213sistema-interamericano-sob-forte-ataque.shtml>. Acesso em: 20 mai. 2018.

${ }^{54}$ ABRAMOVICH, 2009, p. 7. 


\section{2 Âmbito de atuação dos órgãos do Sistema Interamericano}

O Sistema Interamericano divide-se em dois órgãos: a Comissão Interamericana de Direitos Humanos, criada em 1959 e a Corte Interamericana de Direitos Humanos, de 1978. Ambos foram decisivos na proteção das vítimas das ditaduras latino-americanas. E ainda hoje cumprem um papel crucial diante dos graves casos de violação dos direitos humanos.

\subsubsection{Comissão Interamericana de Direitos Humanos}

A CIDH foi criada em 1959 na V Reunião de Consulta de Ministro de Relações Exteriores dos países membros da OEA, por meio de uma resolução. A Comissão foi o primeiro organismo efetivo de proteção de direitos humanos no âmbito do SIDH. Conforme estabelece o artigo 1 do Estatuto da $\mathrm{CIDH}^{55}$, a Comissão Interamericana de Direitos Humanos é um órgão da Organização dos Estados Americanos criado para promover a observância e a defesa dos direitos humanos e para servir como órgão consultivo da Organização nesta matéria ${ }^{56}$.

A Comissão possui sede em Washington, Estados Unidos, sendo integrada por sete membros indicados pelos países membros da OEA e eleitos pela Assembleia Geral da OEA. Possuem mandato de quatro anos e podem ser reeleitos por um período adicional. Os membros elegem anualmente um Presidente e dois Vice-presidentes, além de realizar a cada ano dois períodos ordinários de sessões, e entre um e três períodos extraordinários de sessões ${ }^{57}$.

\footnotetext{
55 Aprovado pela Resolução AG/RES 447 (IX-o/79), adotada pela Assembleia Geral da OEA em seu $9^{\circ}$ Período Ordinário de Sessões, realizado em La Paz, Bolívia, em outubro de 1979.

56 Estatuto da Comissão Interamericana de Direitos Humanos. Disponível em: <http://www.cidh.org/basicos/portugues/t.estatuto.cidh.htm>. Acesso em: 20 mai. 2018.

${ }^{57}$ OEA. Sobre a estrutura do SIDH. Disponível em:

<http://www.oas.org/pt/sobre/comissao_direitos_humanos.asp>. Acesso em: 20 mai. 2018.
} 
Dentre suas atribuições, previstas em seu Estatuto, no Regulamento ${ }^{58}$ e na $\mathrm{CADH}$ estão o estímulo da consciência dos direitos humanos no continente americano e a análise de casos individuais, os quais, após uma revisão preliminar, podem ser submetidos à Corte; a publicação de informações especiais sobre a situação dos direitos humanos em um Estado específico; a realização de vistoria in loco aos países para analisar em profundidade a situação geral, e/ou para investigar em situação particular, com posterior preparação do respectivo relatório, fazer recomendações aos Estados membros da OEA, a adoção de medidas cautelares, solicitação de opiniões consultivas à Corte, dentre outros.

Uma das principais funções exercidas pela CIDH é o recebimento de denúncia, ou seja, o sistema de peticionamento do SIDH, onde pessoas ou organizações questionam a ocorrência de violações de direitos humanos, por parte dos Estados-parte da $\mathrm{OEA}^{59}$, com fundamento na Convenção ou em outros instrumentos normativos do sistema, apresentando uma denúncia por meio do instrumento de petição.

Bernardes ressalta que o recurso ao SIDH acontece hoje pelo o que conhecemos como advocacia de impacto ou litigância estratégica, visto que as organizações da sociedade civil especializada nesse tipo de litígio não remetem à $\mathrm{CIDH}$ qualquer caso, e sim optam por demandas estratégica. Além disso, informa que são levadas petições nos três seguintes critérios: (i) as violações sistemáticas no âmbito interno de um Estado; (ii) violações que não possuem jurisprudência sedimentada no SIDH e que possam colaborar com a construção de novos padrões internacionais de proteção de direitos humanos e (iii) questões humanitárias, onde a vítima encontra-se em extrema vulnerabilidade ${ }^{60}$.

\footnotetext{
${ }^{58}$ Aprovado pela Comissão em seu $137^{\circ}$ período ordinário de sessões, realizado de 28 de outubro de 13 de novembro de 2009; e modificado em 2 de setembro de 2011 e em seu $147^{\text {a }}$ período ordinário de sessões, celebrado de 08 a 22 de março de 2013 para sua entrada em vigor em 01 de agosto de 2013.

${ }^{59} \mathrm{O}$ sujeito passivo do SIDH, tanto na CIDH quanto na Corte IDH é sempre um Estado e não um indivíduo, uma vez que o objetivo do sistema é proteger a vítima.

${ }^{60}$ BERNARDES, Marcia Nina. Sistema Interamericano de Direitos Humanos como esfera Pública Transnacional: Aspectos Jurídicos e Políticos de Implementação de Decisões
} 
Conforme o artigo 46 (1) da Convenção, para que a Comissão possa aceitar uma denúncia é necessário que haja o esgotamento dos recursos da jurisdição interna, tendo em vista o caráter subsidiário do sistema interamericano tem em relação à proteção que deve ser garantida pelos Estados, exceto aqueles casos em que não existir, na legislação nacional, o devido processo legal para a proteção do direito violado; em que não se houver permitido à suposta vítima o acesso à justiça; ou quando houver uma demora injustificada de decisão ${ }^{61}$. Desta forma, o Estado deve investigar e sancionar toda violação dos direitos reconhecidos pela Convenção e buscar o restabelecimento, se possível, do direito violado ${ }^{62}$.

Note-se que também há outros requisitos de admissibilidade, como o prazo $^{63}$ de apresentação da denúncia à $\mathrm{CIDH}$, sendo assim, não pode ter passado os 6 (seis) meses da ciência da violação. E, por fim, o último requisito para admissibilidade do recurso é que não se tenha recorrido a nenhum outro órgão internacional que possua procedimento litigioso em paralelo, o que chamamos de litispendência internacional ${ }^{64}$.

Normalmente a apreciação das petições funciona por ordem de recebimento da denúncia à $\mathrm{CIDH}$, salvo naqueles casos de prioridade, especialmente se houver vítima muito jovem ou idosa, se portadora de enfermidade terminal, de ter riscos da aplicação de pena de morte, lhe foram concedidas medidas cautelares, se a vítima estiver privada de liberdade, ou ainda em casos que a decisão, por alterar a legislação e as práticas do Estado, poderia reparar graves problemas estruturais sérios e evitar múltiplas petições das violações nas práticas do Estado ${ }^{65}$.

\footnotetext{
Internacionais. In: Revista SUR, v. 8, no. 15, dez. 2011. p. 135-156. Disponível em: <https://bdjur.stj.jus.br/jspui/bitstream/2011/46810/sistema_interamericano_direitos_bernardes.pdf $>$. Acesso em: 12 mai. 2018.

${ }^{61}$ De acordo com o artigo 46 (2) da Convenção.

${ }^{62}$ CORTE INTERAMERICANA DE DIREITOS HUMANOS. Caso Velásquez Rodríguez. p. 34, parágrafo 174. Disponível em:

<http://www.corteidh.or.cr/docs/casos/articulos/seriec_04_esp.pdf>. Acesso em: 12 mai. 2018.

${ }^{63}$ De acordo com o artigo 46 (1) (b) da Convenção.

${ }^{64}$ De acordo com o artigo 46 da Convenção.

65 IJRC (International Justice Resource Center). Atuação perante o Sistema Interamericano: Manual para advogados e ativistas, 2014. p. 19 Disponível em: <http://ijrcenter.org/wp-
} 
Portanto, declarada admissível, a CIDH inicia a investigação sobre os fatos do peticionário, podendo solicitar informações e documentos adicionais ao Estado ou às vítimas e realizar oitivas tanto do peticionário quanto do governo. Sendo declarada admissível a petição, a CIDH elabora um informe de admissibilidade e aquela petição transforma-se em um caso. No entanto, se declarada inadmissível pelos fatos alegados ou naqueles casos em que o processo fica parado por longos períodos, em regra, o processo é arquivado.

Desta feita, havendo admissibilidade do caso, a Comissão dá início a fase do mérito, uma vez que já foram apresentadas informações e defesas de ambos os lados e, passa-se, a análise da Comissão para averiguação da existência de violação de direitos humanos.

É necessário destacar um aspecto importante durante esse período na Comissão sobre a possibilidade de adoção de soluções amistosas (artigo 40 do Regulamento da Comissão), isto é, um acordo entre as partes litigantes que interrompe o procedimento. Entretanto, há a necessidade de aquiescência das vítimas e se realizado algum acordo, a CIDH publica o acordo nos termos do artigo 41 do seu Regulamento.

Consequentemente, há duas saídas para decisão da CIDH, uma pela negativa de violação e a outra pela ocorrência de violação, neste caso, a $\mathrm{CIDH}$ pode emitir recomendações para o Estado violador, para que, na medida do possível, restabeleça os direitos violados, impeça a realização de novas violações e, por último, investigue e repare às vítimas.

Caso o Estado não cumpra com as recomendações, a CIDH poderá publicar um relatório de forma pública para pressionar o país e/ou submeter à Corte IDH. Por oportuno, registro que há Estados que não aceitaram a competência da Corte ${ }^{66}$, logo, para esses países só é possível a publicação do relatório sobre a responsabilidade das violações. Entretanto, naqueles

content/uploads/2014/03/Manual-Atuacao-perante-o-Sistema-Interamericano-2014.pdf > . Acesso em: 03 mar. 2018.

${ }^{66}$ Dentre os países que não aceitaram a jurisdição da Corte são EUA, Canadá, Guiana e Venezuela (saiu após a denúncia da Convenção Americana). 
países que aceitaram a competência da Corte IDH, a Comissão poderá submetê-lo à jurisdição da Corte IDH.

Uma característica importante do relatório da Comissão é que no primeiro momento ele é enviado ao Estado de maneira reservada, permitindo que o Estado não sofra nenhum constrangimento internacional. Porém, se não for cumprido em 3 (três) meses, a CIDH elabora um novo informe de modo público e encaminha a Corte IDH.

A segunda principal função desempenhada pela SIDH diz respeito à adoção de medidas cautelares mediante a CIDH, requisitos esses definidos no artigo 25 do Regulamento da CIDH. Nos casos de gravidade e urgência, é possível a adoção de medidas cautelares com o objetivo de prevenir danos irreparáveis às pessoas ou ao objeto relativo a uma petição ou caso pendente. Neste caso, não se exige o esgotamento de recurso, porém, permanece a regra da subsidiariedade.

A CIDH desempenha funções perante a Corte Interamericana de Direitos Humanos, tendo em vista que submete ao entendimento da Corte, casos nos quais os Estados não tenham cumprido as recomendações elaboradas por essa Comissão.

\subsubsection{Corte Interamericana de Direitos Humanos}

A Corte Interamericana de Direitos Humanos foi criada em 1969, por previsão da CADH, consiste em um órgão jurisdicional do SIDH, com sede em São José, Costa Rica. No entanto, vale mencionar que ela só começou efetivamente funcionar em 1979, após a entrada em vigor do referido tratado em 1978. Nesse sentido, é uma instituição autônoma da OEA cujo objetivo é a aplicação e interpretação da $\mathrm{CADH}$ e de outros tratados concernentes aos direitos humanos.

A Corte é composta por sete juízes, nacionais dos Estados membros da OEA, com mandato de seis anos, podendo ser reconduzidos uma vez mais pelo mesmo período. A escolha é realizada por votação secreta por 
maioria absoluta de votos durante a Assembleia da OEA, dentre os 3 (três) candidatos indicados para o cargo de Juiz do Estado-partes da CADH. A Corte é um tribunal não permanente, que se reúne por alguns períodos ordinários de sessões e dois extraordinários ao longo do ano, exercendo duas competências distintas: a consultiva e a contenciosa.

A competência consultiva está prevista na disposição do artigo 64 da Convenção Americana, onde a Comissão Interamericana, os Estados membros da OEA, parte ou não da $\mathrm{CADH}$, podem consultar a Corte IDH solicitando uma interpretação sobre a norma, por conseguinte, a Corte possui essa faculdade de emitir pareceres consultivos em matéria de direitos humanos. Sabe-se que esses pareceres emitidos quando exercido por meio de competência consultiva recebe o nome de Opiniões Consultivas, podendo ser de 3 (três) tipos: a) as que se destinam a interpretar a $\mathrm{CADH}$; b) as que têm por fim a interpretação de outros tratados de proteção dos direitos humanos nos Estados Americanos; e c) as que analisam a compatibilidade das leis internas dos Estados membros com a CADH ou outros tratados concernentes à proteção dos direitos humanos nos Estados Americanos ${ }^{67}$.

Por sua vez, a função contenciosa diz respeito ao conhecimento dos casos individuais em que se alegam violações de direitos humanos consagrados em instrumentos normativos por Estado Parte. Segundo Flávia Piovesan, a competência contenciosa tem caráter jurisdicional, referente à solução de controvérsias que se apresentem acerca da interpretação ou aplicação da própria convenção ${ }^{68}$.

A competência contenciosa da Corte está respaldada nos artigos 61, 62 e 63 da CADH. É válido destacar que conforme o artigo 61 da

\footnotetext{
${ }^{67}$ PIZZOLO, Calogero. Sistema Interamericano: La denuncia ante La Comision Interamericana de Derechos Humanos, El processo ante La Corte Interamericana de Derechos Humanos, Informes y Jurisprudência. 1ª ed. Buenos Aires: 2011, p. 399 apud SCHETTINI, Andrea Bandeira de Melo; FERREIRA, Natalia Damazio Pinto. Uma introdução ao Sistema Interamericano de proteção dos direitos humanos: reflexões sobre sua história, estrutura e o recente posicionamento do Estado Brasileiro. CONPEDI, 2016. p. 164. Disponível em: <https://www.conpedi.org.br/publicacoes/y0ii48h0/va83towp/d8E6kevG2W3HUq56.pdf>. Acesso em: 12 mai. 2018.

${ }^{68}$ PIOVESAN, 2013, p. 139.
} 
Convenção Americana, apenas a CIDH e os Estados parte de tal convenção tem legitimidade para submeter um caso à decisão da Corte. Da mesma forma, para que a Corte possa conhecer de qualquer caso, é necessário que sejam esgotados os processos previstos nos artigos 48 a $50^{69}$.

Vale mencionar que essa competência desenvolve-se em três funções, tais como: análise do caso de violação de direitos humanos, supervisão do cumprimento da sentença e adoção de medidas provisórias. A primeira corresponde à análise do caso ${ }^{70}$ submetido à Corte para investigar e consequentemente informar se o Estado tem ou não responsabilidade internacional pela suposta violação arguida. Entretanto, antes de averiguar se o Estado possui a responsabilidade, a Corte faz um juízo de admissibilidade, mérito e as reparações.

É de primordial importância abordar a mudança do Regulamento da Corte IDH no final de 2009 com o objetivo de fortalecimento da CIDH, permitindo um papel mais ativo das vítimas e dos peticionários dos casos, embora ainda caiba à $\mathrm{CIDH}$ iniciar o procedimento perante a Corte. Por conseguinte, a Comissão apenas apresenta um relatório de mérito, conforme previsto no artigo 50 da $\mathrm{CADH}$.

Pode acontecer que as vítimas não tenham representação legal para o litígio perante a Corte, à vista disso, o Regulamento criou a figura do

\footnotetext{
${ }^{69}$ Artigo 61.2 da CADH.

70 Resumo da análise do caso: (i) a CIDH apresenta um informe à Corte que, por sua vez, comunica às vítimas e ao Estado; (ii) as vítimas, através de seus representantes, apresentam um escrito de petições, argumentos e provas, no qual expõem o fundamento jurídico do caso e suas pretensões em matéria de reparações; (iii) o Estado, após ser notificado, tem o prazo de dois meses para apresentar sua contestação e, se for o caso, interpor exceções preliminares; (iv) as partes enviam seus escritos contendo as indicações de testemunhos e peritos; (v) é realizada uma audiência pública para que os juízes analisem as provas; (vi) cada parte apresenta suas alegações finais por escrito; (vii) a Corte emite a sentença do caso, determinando a responsabilidade ou não do Estado pelas violações alegadas e definindo o alcance das reparações devidas.

CEJIL (Centro por la Justicia y el Derecho Internacional). Guia para defensores y defensoras de Derechos Humanos. $2^{\mathrm{a}}$ ed. Buenos Aires, 2012. p. 103 apud SCHETTINI, Andrea Bandeira de Melo; FERREIRA, Natalia Damazio Pinto. Uma introdução ao Sistema Interamericano de proteção dos direitos humanos: reflexões sobre sua história, estrutura e o recente posicionamento do Estado Brasileiro. CONPEDI, 2016. p. 165. Disponível em: <https://www.conpedi.org.br/publicacoes/y0ii48h0/va83towp/d8E6kevG2W3HUq56.pdf>. Acesso em: 12 mai. 2018.
} 
Defensor Interamericano ${ }^{71}$, podendo ser uma pessoa ou grupo de pessoas para defesa daquele caso específico. Ou seja, há uma valorização do papel das vítimas no procedimento internacional. Infelizmente, esse processo ainda é custoso, devido ao deslocamento para a sede da Comissão ou da Corte, o envio de matérias e todos os trâmites processuais para a possível análise.

A segunda função refere-se a supervisão do cumprimento de sentença de acordo com o artigo 65 da CAD, onde a Corte fiscaliza a determinação adotada, solicitando informações às vítimas e ao Estado sobre as atividades desenvolvidas ou não. E, posteriormente, encaminha essa resposta para a Assembleia Geral da OEA.

Já a última função é a implementação de medidas provisórias. Segundo o artigo 63 da Convenção Americana, nos casos de extrema gravidade e urgência, quando se faça necessário evitar danos às pessoas, a Corte poderá adotar medidas provisórias, do mesmo modo, pode ditar medidas provisórias a pedido da $\mathrm{CIDH}$.

Em suma, o caminho percorrido pelo SIDH demonstrou avanços e resultados significativos. Além disso, potencializou a atuação dos indivíduos e das organizações não governamentais na esfera de litigância internacional. Vale destacar o espaço aberto para diálogo entre as vítimas, organizações sociais e governos, sendo expressivo o crescimento do número de usuários do SIDH.

\footnotetext{
${ }^{71}$ A figura do Defensor Público Interamericano foi incorporada ao sistema interamericano por meio de uma reforma estrutural, na qual as vítimas passaram a ter locus standi no procedimento perante a Corte Interamericana. Para mais informações, acessar o Acordo de Cooperação Geral entre a Secretaria Geral da OEA e a AIDEF, disponível em: <https://www.mpd.gov.ar/users/uploads/1402684164Acuerdo\%20final\%20OEA\%20AIDEF.pdf> e Acordo de Entendimento entre a CIDH e a Associação Interamericana de Defensorias Públicas <https://www.mpd.gov.ar/index.php/component/content/article/126-internacional/aidef/470reglamento-unificado-aidef-ante-cidh-y-corteidh-aprobado-en-antigua-guatemala-el-7-de-junio-de2013.html? Itemid=101>. Acesso em: 12 maio 2018.
} 


\subsection{Do litígio estratégico no Sistema Interamericano de Direitos Humanos}

Após termos estudado a origem e o funcionamento do SIDH, a partir de agora começaremos a analisar como funciona o litígio de impacto dentro da arena do Sistema Interamericano. Sendo assim, este tópico será dividido em duas partes. A primeira trabalharemos a atuação dos atores sociais na promoção da Justiça Social, enquanto que na segunda abordaremos a divisão de fases do litígio internacional proposta pela autora Evorah Cardoso.

Desde os anos 90, como parte do processo de globalização, nós temos testemunhado o aumento da transnacionalização das instituições legais e da mobilização jurídica, dois lados de um fenômeno denominado pelos juristas de "judicialização global"72" e "litigância internacional"73.

Santos observa que o ativismo jurídico transnacional seria um tipo de ativismo focado na ação legal engajada, através das Cortes Internacionais e instituições quase judicias, em fortalecer as demandas dos movimentos sociais; realizar mudanças legais e políticas internas; reestruturar ou redefinir direitos; e/ou pressionar os Estados a cumprir as normas internacionais e internas dos direitos humanos ${ }^{74}$.

Desta forma, podemos compreender que o ativismo jurídico transnacional consiste nessa tentativa do uso do litígio de impacto para (re)discutir políticas internas e reestruturar os direitos provocando o âmbito das arenas das cortes internacionais ou/e os sistemas interamericanos de direitos.

\footnotetext{
${ }^{72}$ Ela surge através da criação de cortes internacionais ad hoc ou permanentes e tribunais arbitrais, bem como por intermédio de crescente recurso às instituições internacionais judiciais ou quase judiciais para lidar com as disputas sobre questões comerciais e direitos humanos.

${ }^{73}$ SANTOS, 2007, p. 27.

${ }^{74}$ Ibid., p. 28.
} 


\subsubsection{Atuação dos atores sociais na promoção da Justiça Social}

Como bem afirma Evorah Cardoso, os atores sociais ao participarem do sistema interamericano podem ter como objetivo ser um agente de um processo normativo transnacional, por exemplo, para a tematização e reconhecimento de direitos ${ }^{75}$. Assim sendo, a apropriação consciente do processo normativo transnacional pelos atores sociais pode ser traduzida em um discurso prática, denominado litigio estratégico, isto é, mobilização direcionada a um tipo determinado fórum ${ }^{76}$. Nota-se, que a autora relaciona a ideia do litígio estratégico como indissociável dos atores.

Percebe-se, que a atuação dos atores não-estatais é peça fundamental para avaliação dos casos de litígio. Por isso, declara Villarreal que alguns grupos internacionais de advogados de interesse público consideram que o melhor momento para recorrer ao litígio estratégico são nas seguintes situações: (i) se o direito não for observado; (ii) se houver discordância com padrões internacionais, buscando as melhores práticas para esclarecer a lei existente; (iii) quando há aplicação errada e arbitrária da lei; (iv) aplicação dos direitos econômicos, sociais e culturais vs. Civis e políticos dentre outros $^{77}$.

Nessa seara, a autora utiliza como referência o Handbook for legal professionals and activits $^{78}$, elaborado pela Public Interess Law Initiative in Transitional Societies da Columbia University School of Law, para afirmar outros possíveis momentos para o litígio: (i) quando as leis boas são letra morta; (ii) quando a aplicação do direito, seja pelas autoridades ou até mesmo pelos próprios tribunais é incerto, imprevisível, isto é, quando é impossível saber com certeza o caminho; (iii) quando as restrições estão estruturalmente imersas na lei, ou seja, a fonte das violações é a própria lei;

\footnotetext{
${ }^{75}$ CARSOSO, 2012, p. 39.

${ }^{76}$ Ibid. p. 40.

77 VILLARREAL, 2007. p. 22.

${ }^{78}$ Para mais informações, ver o documento no site. Disponível em: < https://www.pilnet.org/public-interest-law-resources/35-pursuing-the-public-interest-ahandbook-for-legal.html>. Acesso em: 12 mai. 2018.
} 
(iv) a existência de standard de internacionais que possa ser utilizado pelos Estados como padrão e; (v) reconhecimento do direito em sentença.

Ao seu turno, a Child Rights International Network (CRIN) destaca que o litígio estratégico não faz sentido para todos os casos e provavelmente não será sempre necessário interpor uma demanda para alcançar uma meta, até porque o litígio costuma ser custoso. Por conseguinte, cada litígio deve ser analisado e investigado e somente deve ser apresentado naqueles casos em que foi observado minuciosamente os direitos, as evidências, os argumentos para apresentar a demanda ${ }^{79}$.

Montoya afirma que para o desenvolvimento do litígio de alto impacto é necessário a reunião de três componentes, compreendidos em componente judicial, político e comunicativo ${ }^{80}$. O componente judicial é justificado na medida em que é identificado a problemática social envolve uma violação da lei ou uma ameaça latente de danos, na qual se pode responsabilizar o Estado por aqueles direitos sociais e coletivos. Além do mais, a equipe estratégica deve possuir uma interdisciplinaridade de modo a empoderar aquela comunidade dos seus direitos básicos, visando garantir a participação comunitária na construção do caso.

Já o segundo componente, político, corresponde ao alcance de uma mudança no campo específico de um programa ou um projeto governamental, como também a capacidade de influir com poder de decisão. Com outras palavras, visa fortalecer a sociedade civil, promovendo uma participação da sociedade na utilização dos seus direitos humanos constitucionais. Por último, o componente comunicativo, insta transmitir o planejamento idealizado e ao mesmo tempo propõe influenciar e pressionar a opinião pública.

Importante destacar que autores como James L. Cavallaro e Stephanie Erin Brewer defendem esses caminhos alternativos que os

79 CRIN (Child Rights International Network), Cuàndo Debría de Tramitarse El Litigio Estratégico? 2008. Disponível em: <https://www.crin.org/en/library/publications/cuando-deberiade-tramitarse-el-litigio-estrategico>. Acesso: 19 mai. 2018.

${ }^{80}$ MONTOYA, 2008, p. 156. 
litigantes utilizam para promoção da justiça social através da litigância no Sistema Interamericano ${ }^{81}$. Argumentam que os advogados de direitos humanos promoverão melhor tais direitos quando usarem a litigância supranacional como uma ferramenta subsidiária a fim de apoiar os esforços estratégicos liderados por movimentos sociais internos, papel esse que pode frequentemente conduzir à inserção estratégica de reivindicações ligadas aos direitos econômicos, sociais e culturais (ESC) dentro da estrutura de violações a direitos civis e políticos. Afirmam que, com frequência, esse é o caso dos litígios ajuizados perante a Corte Interamericana de Direitos Humanos $^{82}$.

Além disso, recomendam o emprego de construções expansivas dos direitos civis e políticos a fim de englobar elementos dos direitos ESC ou propor petições que tratem tanto de violações de direitos civis e políticos, quanto de direitos $\mathrm{ESC}^{83}$.

Destaca os autores que conforme defendido no trabalho publicado na Revista Hasting, o impacto concreto das determinações provenientes da Corte não está diretamente relacionado com os méritos de tais determinações; antes, tem variado conforme as estratégias assumidas por organizações paralelas ao caso, pela mobilização da mídia e pela sociedade civil $^{84}$.

Portanto, aqueles que utilizam a litigância como principal veículo para promover os direitos humanos, deve reconhecer e apoiar a mobilização de movimentos sociais, sociedade civil e mídia, considerando que objetivam promover a justiça social. Como é cediço, muitos, senão a maioria dos advogados de direitos humanos, já reconhecem que a litigância possui maior potencial de impacto quando ocorre em conjunto com a

\footnotetext{
${ }^{81}$ CAVALLARO; James L.; BREWER, Stephanie Erin. O papel da litigância para a justiça social no Sistema Interamericano In: SUR - Revista Internacional de Direitos Humanos. ano 5, n. ${ }^{\circ}$, São Paulo, junho de 2008, p. 86. Disponível em: <https://bdjur.stj.jus.br/jspui/handle/2011/18129>. Acesso em: 12 mai. 2018.

${ }^{82}$ CAVALLARO; BREWER, 2008, p. 85.

${ }^{83}$ Ibid., p. 95.

${ }^{84}$ Ibid., p. 87.
} 
mobilização promovida pelos movimentos sociais, com cobertura pela mídia e com outras formas de pressão doméstica e internacional ${ }^{85}$.

Cavallaro e Schaffer explicam essa correlação ${ }^{86}$, vejamos:

A sociedade civil pode procurar a efetivação de direitos individuais através do recurso aos mecanismos de proteção aos direitos humanos do Sistema Interamericano de Proteção aos direitos humanos; a seu turno, o sistema precisa do apoio da sociedade civil para sua legitimidade. Governos fornecem os recursos necessários para manter o sistema interamericano funcionando e elegem os indivíduos que vão servir como comissionados ou juízes nos seus órgãos de monitoramento; mas essas instituições também dependem da aceitação voluntária da sua autoridade e participação com boa-fé nas regras de engajamento estabelecidas para que serem efetivas. E essas instituições que compõem o sistema têm a autoridade para resolver demandas e emitir decisões requerendo a ação tanto dos governos quanto de atores da sociedade civil; mas essa autoridade depende da percepção desse último grupo de que ela é exercida de modo razoável e apropriado.

Bernardes assevera que não há dúvidas entre os que militam no Sistema Interamericano de Direitos Humanos (SIDH) de que a litigância estratégica constitui uma ferramenta importante para promoção de direitos humanos. Relata que ao longo do contencioso internacional e das muitas trocas entre atores estatais e da sociedade civil de diferentes nacionalidades, determinadas práticas são criticadas, novos repertórios de ação são adquiridos e a assimetria de poder entre Estado e indivíduo pode ser mitigada. Tais efeitos podem resultar de genuínos processos de aprendizado e consolidação democrática, que podemos chamar de processos de desenvolvimento de consciência (awareness raising) ou de estratégias de pressão política, criando-se constrangimentos para Estados que se dizem democráticos (embarassement power $)^{87}$.

Essa perspectiva de trazer a sociedade civil para o SIDH constitui uma estratégica dos atores sociais, de modo que a sociedade possa exigir

\footnotetext{
${ }^{85}$ CAVALLARO; BREWER, 2008, p. 88.

${ }^{86}$ CAVALLARO, J.L; SCHAFFER, E.J. 2004. Less as More: Rethiking Supranational Litigation of Economic and Social Rights in the Americas. 2004 apud BERNARDES, Marcia Nina. Sistema Interamericano de Direitos Humanos como esfera Pública Transnacional: Aspectos Jurídicos e Políticos de Implementação de Decisões Internacionais. In: Revista SUR, v. 8, no. 15, dez. 2011. p. 140. Disponível em:

<https://bdjur.stj.jus.br/jspui/bitstream/2011/46810/sistema_interamericano_direitos_bernardes.pdf >. Acesso em: 12 mai. 2018.

${ }^{87}$ BERNARDES, 2011, p. 140.
} 
seus direitos fundamentais violados. Por isso, enfatiza Bernardes que o SIDH proporciona as bases institucionais para a construção de uma esfera pública transnacional que pode contribuir para a ampliação da democracia brasileira $^{88}$.

\subsubsection{Das etapas do litígio estratégico no SIDH}

Cardoso elucida o litígio estratégico no Sistema Interamericano de Direitos Humanos como um ciclo $^{89}$, dividido em quatro etapas que envolve desde o momento da escolha do caso até a implementação das decisões pela Corte Interamericana de Direitos Humanos.

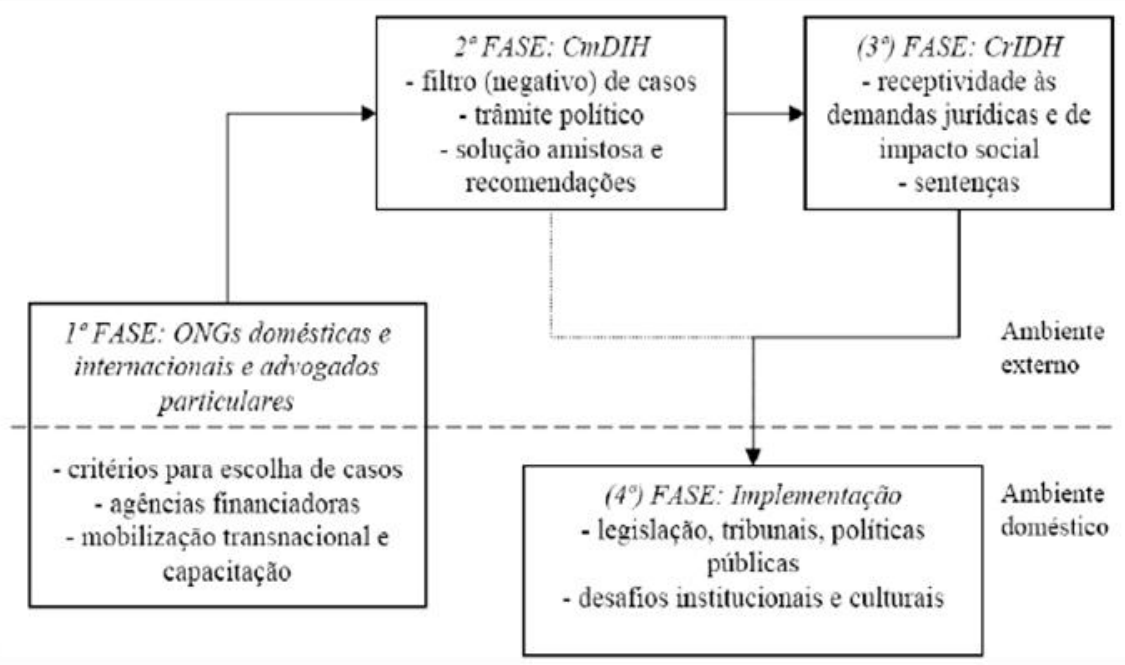

Figura 1 - Ciclo de vida do litígio estratégico no SIDH

A primeira etapa é o momento em que os casos são escolhidos pelos atores sociais de acordo com os objetivos e estratégias daquele litigante. Muitas das vezes, a escolha se dá por uma parceria entre as ONGs maiores com as ONGs menores, de forma que as ONGs maiores levam os casos coletados pelas ONGs menores para o sistema interamericano. Esse

\footnotetext{
${ }^{88}$ BERNARDES, 2011, p.136.

${ }^{89}$ A organização do manual da ONG Internacional Interights sobre litigio estratégio parece sugerir a mesma abordagem, conforme os tópicos de seu índice ("case selection", "the process of strategic litigation planning", "case management and strategy", "post-litigation implementation"). ERRC, Acesso em: 15 abr. 2018.
} 
movimento acontece porque essas ONGs maiores possuem maior aptidão e conhecimento especializado no sistema, resultando assim em uma cooperação proveitosa para ambas as partes, dado que a ONG maior pode acompanhar com mais afinco o trâmite no caso, bem como pode impulsar melhor o andamento do processo, enquanto que a ONG local cuida do atendimento à vítima e promove a divulgação do tema no âmbito doméstico.

Outrossim, o sistema também pode ser acionado por meio de advogados particulares, entretanto, o número de atores com esse enfoque é bem reduzido, uma vez que grande é dificuldade encontrada no momento do financiamento do processo ainda é extremamente custoso, tendo em vista a necessidade de deslocamento para a sede da Comissão ou da Corte, de envio de materiais e de todos os demais recursos fundamentais para o trâmite adequado dos casos.

Bernardes afirma que em geral são enviados à CIDH petições selecionadas a partir de três critérios principais: (a) casos que retratem cabalmente padrões sistemáticos de violação de direitos humanos internamente; (b) casos que levantem temas sobre os quais a Corte IDH ou a CIDH não tenham ainda se pronunciado claramente, visando colaborar com a construção de novos padrões internacionais de proteção dos direitos humanos; e (c) casos humanitários, em que a situação de extrema vulnerabilidade da vítima justifica o litígio, ainda que não se produza nenhum dos outros efeitos mencionados ${ }^{90}$.

Em suma, Bernardes destaca que é realizada uma avaliação estratégica à luz do contexto político-jurídico do país e o próprio objetivo no SIDH. Ressalto que, normalmente, estratégias que obtém maiores resultados são aquelas que acompanham um processo de mobilização e ativismo político dos protagonistas. Portanto, a estratégia de impacto parte da identificação de uma problemática social e como processo de

\footnotetext{
${ }^{90}$ BERNARDES, 2011, p. 145.
} 
intervenção se esforça a buscar uma solução integral através de componentes interdisciplinares e interrelacionados.

A CmIDH corresponde a segunda etapa do litígio estratégico onde há o recebimento da denúncia de violações de direitos humanos previstos na Convenção Americana de Direitos Humanos ou em outros instrumentos normativos do SIDH, cometidas por Estados-parte da OEA. Ato contínuo, é realizada a análise dos requisitos formais para sua admissibilidade, e sendo declarada admissível, a CIDH inicia a investigação sobre os fatos, podendo solicitar informações e documentos adicionais.

Não se sabe os critérios utilizados pela Comissão para recebimento dos casos, bem como sobre a submissão do caso à Corte IDH. No entanto, não se pode negar que a Comissão tem realizado boas soluções amistosas entre vítimas e Estados, por meio de medidas de impacto coletivo e muitas vezes alcançando promulgação de leis ou alterações políticas de direito humanos na jurisprudência doméstica do país violador. Ademais, quando não realizada a solução amistosa, a Comissão com base no artigo 50 da $\mathrm{CADH}$, redigirá um relatório de mérito ${ }^{91}$ atribuindo responsabilidade do Estado pela violação de direitos humanos, expondo o Estado aos efeitos chamado de power of shaming ou de tematização doméstica.

Todavia, se o objetivo da litigância for atingir a formação de um precedente, de modo que possa influenciar e restringir outros casos futuros ou países da região, os representantes das vítimas deverão agir com a finalidade do caso ser encaminhado à Corte IDH.

A terceira fase diz respeito aos diferentes procedimentos e mecanismos de participação estratégica dos atores não estatais na decisão da Corte IDH, de sorte que os atores não estatais podem apresentar demandas de maneira autônoma, não necessariamente sendo parte da demanda. No entanto, destaco que essa atuação estratégica também inclui a participação da vítima - após reforma de 2000 - como parte do processo

\footnotetext{
91 Apesar do Relatório de mérito atribuir responsabilidade ao Estado, ele não possui caráter vinculante, ou seja, não tem caráter obrigatório.
} 
podendo atuar de maneira diferenciada dos próprios representantes com o fito de lograr êxito na demanda.

Observamos que no tópico do funcionamento da Corte IDH que esse órgão possui duas competências principais, a consultiva e a contenciosa. As opiniões consultivas interpretam direitos da Convenção Americana e de outros tratados em determinadas situações hipotéticas apresentados em consulta à Corte IDH, ou ainda, quando solicitados por algum Estado, as opiniões consultivas analisam a compatibilidade da legislação doméstica a essa normativa internacional ${ }^{92}$. Nestes casos, não há partes em litígio, no entanto, a interpretação dada pela Corte pode servir como base para um caso contencioso, formando precedentes.

Por outro lado, temos os casos contenciosos que decidem sobre situações concretas, possuem partes e litígio e, obviamente, uma pretensão de sentença. A sentença da Corte poderá reconhecer a responsabilidade internacional do Estado e instituirá medidas de reparação, compensação e satisfação.

Nesse sentido, Cardoso ressalta que nos casos consultivos, apenas é possível a estratégia jurídica, pois a Corte não estabelece qualquer medida para cumprimento do Estado, já nos casos contenciosos são possíveis a estratégia jurídica e a de impacto social. As medidas de reparação individual nos casos contenciosos são consideradas parte do litígio tradicional e não do estratégico, pois este tem como característica transcender a decisão do caso concreto, buscando o máximo de repercussão $\operatorname{social}^{93}$.

Por fim, a última fase corresponde a implementação da decisão por parte dos organismos domésticos dos Estados das "decisões" tidas na Comissão Interamericana e na Corte Interamericana. A grande questão que se coloca nessa fase é a dificuldade do processo de implementação das decisões da Corte internalizado na estrutura institucional doméstica, isso

\footnotetext{
${ }^{92}$ CARSOSO, 2012, p. 90-91.

${ }^{93}$ Ibid., p. 91.
} 
ocorre pelas próprias dificuldades brasileiras como, por exemplo, o sistema federativo, dificuldades de ordem cultural, desconhecimento do sistema interamericano pela grande parte dos tomadores de decisão e a própria desvalorização do sistema no âmbito doméstico.

Em síntese, é fundamental um movimento interno de cultura dos órgãos nacionais (Poderes legislativo, executivo e judiciário) para promover o respeito à normativa internacional. Tal qual ocorra um movimento externo reconhecendo a importância do sistema ao assegurar direitos no continente americano que foram violados, ou seja, o cumprimento das recomendações e sentenças advindas do SIDH.

Diante de todo o exposto, podemos observar que a globalização dos direitos humanos e a transnacionalização dos movimentos sociais têm contribuído para a expansão do ativismo jurídico transnacional. Como resultado desses processos, a $\mathrm{CIDH}$ tem ganhado mais credibilidade entre as ONGs de direitos humanos e pressionado os Estados membros da OEA a reconhecer e cumprir as normas de direitos humanos ${ }^{9495}$. Resta evidente, que esse crescimento só está sendo em potencial, considerando as estratégias e as ferramentas utilizadas pelos atores sociais.

Contudo, não se pode negar que as estratégias do ativismo jurídico transnacional enfrentam dois tipos de limitações. Primeiro, a mobilização jurídica apenas não é suficiente para promover mudanças sociais. Em segundo lugar, as normas internacionais de direitos humanos dependem dos Estados nação para o seu reconhecimento e cumprimento. Por depender das condições políticas locais, nacionais e internacionais, o Estado pode estar mais ou menos aberto a reconhecer tais normas ${ }^{96}$.

\footnotetext{
${ }^{94}$ SANTOS, 2007, p. 37.

95 Além disso, destaca a autora Cecília Santos que a credibilidade do SIDH entre as ONGs de direitos humanos e a avaliação positiva dos efeitos de suas decisões estão exemplificadas no seguinte artigo feito pelos membros do Centro para Justiça e Direito Internacional (CEJIL). AFFONSO, Beatriz; FREUND, Rita Lamy. Efeitos Práticos das Decisões dos Órgãos do Sistema Interamericano de Direitos Humanos. Disponível em: <https://www.social.org.br/relatorio2005/relatorio035.htm>. Acesso em: 12 mai. 2018.

96 SANTOS, 2007, p. 50.
} 
De fato, como é característico desse sistema jurídico possuir bases em dispositivos legais interpretados pelos tribunais competentes e que essas decisões dependam do Estado nação para o reconhecimento, visualizamos assim a figura do controle de convencionalidade ${ }^{97}$.

Não obstante, o objeto desse trabalho não versar sobre o controle de convencionalidade, a temática está diretamente relacionada a promoção de um litígio de impacto e a implementação do dever de interpretação desse standard da norma internacional ao ordenamento interno de cada País. Em linhas gerais, o controle de convencionalidade é um processo de verificação de (in)compatibilidade dos atos internos e normas jurídicas dos Estadosparte em relação aos tratados internacionais.

Nesse sentido, pode-se entender no dever conferido ao aparato estatal de zelar para que as disposições dos tratados internacionais de direitos humanos não sejam restringidas pela aplicação de leis nacionais contrárias ao objetivo fim da $\mathrm{CADH}$, ou seja, de respeitar o exercício dos direitos e liberdades conferidos na Convenção, garantindo o seu livre e exercício sem qualquer discriminação alguma por motivo de raça, cor, sexo, idioma, religião, opiniões políticas ou de qualquer outra natureza, origem nacional ou social, posição econômica, nascimento ou qualquer outra condição social.

Isto posto, para a melhor compreensão desse standard interamericano, passar-se-á, em um capítulo próprio, à exposição e análise do caso Fazenda Brasil Verde vs. Brasil.

\footnotetext{
${ }^{97}$ Sugestão do artigo do Valério de Oliveira Mazzuoli intitulado como Teoria geral do controle de convencionalidade no direito brasileiro. Disponível em: < http://www2.senado.leg.br/bdsf/item/id/194897>.
} 


\section{CAPÍTULO 3 - O CASO FAZENDA BRASIL VERDE VS. BRASIL}

Nesse último capítulo, analisaremos o primeiro caso de condenação de trabalho escravo decidida pela Corte IDH que é brasileira ${ }^{98}$. Nela, foi reconhecida a responsabilidade pelas violações de direito de liberdade e ao direito de não ser submetido a qualquer forma de escravidão ou servidão, o direito de acesso à justiça, a garantias judiciais e o direito à razoável duração do processo das 85 vítimas escravizadas em 2000 na Fazenda Brasil Verde.

No entanto, é preciso esclarecer que não foi o primeiro caso de exploração de trabalho escravo no Brasil denunciado no Sistema Interamericano de Direitos Humanos. A primeira denúncia que chegou na CIDH foi o Caso José Pereira ${ }^{99}$, todavia, o desfecho internacional foi distinto da Fazenda Brasil Verde, dado que resultou em um acordo amistoso e não houve encaminhamento para a Corte IDH.

Feitas tais considerações, iniciaremos a análise do caso objeto deste capítulo e veremos que a Corte sustentou um marco de uma situação de discriminação estrutural histórica em razão da posição econômica, decorrente da pobreza e elevada concentração de propriedade de terras.

\footnotetext{
${ }^{98}$ FREUND, Rita. O primeiro caso de trabalho escravo decidido pela Corte Interamericana de Direitos Humanos é brasileiro. Escola Superior da Defensoria Pública da União. Disponível em: $\langle$ http://www.dpu.def.br/images/esdpu/jornaldpu/edicao_8/4-o-primeiro-caso.pdf $>$. Acesso em: 15 mai. 2018.

${ }^{99}$ Nesta situação, em dezembro de 1994, as ONGs CEIL e Human Rights Watch apresentaram à CIDH reclamação denunciando a prática de trabalho escravo em condições análogas à de escravo no Brasil e, em especial, na Fazenda Espírito Santo (PA), à qual afluíram inúmeros trabalhadores, lubrificados por falsa promessas, entre eles o sr. José Pereira. Este, em especial, foi gravemente ferido e outro trabalhador rural foi assassinado, ao tentarem escapar do local em 1989. (...) De acordo com a $\mathrm{CIDH}$, embora os agentes estatais não tivessem envolvidos nos eventos acima relatados, o Brasil deveria ser responsabilizado por sua omissão em prevenir a ocorrência de trabalho forçado e em aplicar sanções adequada aos culpados. Foram constatadas violações aos direitos à vida, à liberdade e à segurança pessoal, à proteção contra prisão arbitrária, à proibição da escravidão e da servidão, a um julgamento justo e a proteção judicial. Houve um acordo assinado pelas partes em dezembro de 2003, que garantiu ao Sr. José Pereira o recebimento de indenização pelos danos sofridos, e também serviu para que o Brasil assumisse o compromisso de combater à escravidão em todo o território nacional.

AZEVEDO NETO, Platon Teixeira de. A justiciabilidade dos Direitos Sociais nas Cortes Interamericanas de Justiça. São Paulo: LTr, 2017. p.187.
} 
Além disso, fixou diversos outros elementos constitutivos do fenômeno da prática de trabalho análogo ao escravo, consolidando parâmetros importantes para os países integrantes da Organização dos Estados Americanos, permitindo a identificação, prevenção, combate e sanção ao trabalho escravo.

Saliento que a Fazenda Brasil Verde está localizada no município de Sapucaia, no sul do Estado do Pará. A área total da Fazenda é de 1.780 alqueires (8.544 hectares), onde se criam cabeças de gado e o proprietário no momento dos fatos era João Luis Quagliato Neto, um dos maiores criadores de gado do Norte do país, com cerca de 130 mil cabeças de gado 100 .

Sobre os proprietários da fazenda, Ricardo R. Figueira, Coordenador do Grupo de Pesquisa de Trabalho Escravo Contemporâneo da Universidade Federal do Rio de Janeiro (GPTEC/UFRJ), nos diz:

[...] donos de imensas propriedades repletas de gado e, repetidas vezes, de escravos, conforme denúncias da CPT e de funcionários do Ministério do Trabalho, mantêm relações com o mundo político e empresarial e hospedam os reis da Suécia sem suas terras ${ }^{101}$.

Feitas tais considerações iniciais, informo que nesse último capítulo veremos os aspectos práticos do que abordamos nos primeiros capítulos. Em vista disso, será feito um breve resumo sobre os fatos do caso e das considerações da Comissão IDH. Posteriormente, examinaremos os fundamentos, determinações e medidas estipuladas pela Corte IDH e, por fim, traremos considerações sobre o desafio da sentença da Corte por diversos atores sociais.

\footnotetext{
${ }^{100}$ CORTEIDH (Corte Interamericana de Derechos Humanos). Sentença do Caso Trabalhadores da Fazenda Brasil Verde vs. Brasil, 2016. Disponível em: 〈http://www.corteidh.or.cr/docs/casos/articulos/seriec_318_por.pdf〉. Acesso em: 15 mai. 2018. 101 FIGUEIRA, Ricardo Rezende. O trabalho escravo contemporâneo por dívida: como se manifestam os acusados? Conferência na Universidade Salgado Oliveira, 2002 apud ROCHA, Cristina Costa. Trabalhadores da Fazenda Brasil Verde vs; Brasil: trajetórias de luta por justiça de trabalhadores escravizados. Disponível em: <http://wpro.rio.rj.gov.br/revistaagcrj/wpcontent/uploads/2016/12/Dossi\%C3\%AA_Artigo-3.pdf>. Acesso em: 06 jan. 2018.
} 


\subsection{Dos fatos do caso}

O cenário da Fazenda Brasil Verde foi, por muitos anos, de submissão dos seus empregados ao trabalho forçado em condições degradantes, com a restrição de sua liberdade, uma vez que não eram livres para ir embora, sendo mantidos presos na Fazenda sob ameaças e coação. Além disso, muitos trabalhadores ficavam submetidos àquela situação, por conta de uma suposta servidão por dívida e, devido à sua condição de extrema pobreza, isto é, sua situação de vulnerabilidade.

O perfil desses trabalhadores, em sua maioria homens pobres, "afrodescendentes ou mulatos", entre 18 e 40 anos de idade, recrutados em seus estados de origem por "gatos", para trabalhar em estados distantes, com a promessa de salários atrativos. Ao chegarem às fazendas, os trabalhadores são informados de que estão em dívida com seus contratantes por seu transporte, alimentação e hospedagem. Os salários prometidos são reduzidos e não cobrem os custos já assumidos. Em alguns casos, os trabalhadores se endividam cada vez mais, pois têm de comprar tudo o que necessitam nos armazéns das fazendas, a preços elevados. Sua dívida aumenta tanto que nunca podem pagá-la e se veem obrigados a continuar trabalhando ${ }^{102}$.

Geralmente, a maior quantidade de vítimas de trabalho escravo no Brasil são trabalhadores originários das regiões norte e nordeste, dos estados que se caracterizam por serem os mais pobres, com maiores os maiores índices de analfabetismo e de emprego rural: Maranhão, Piauí e Tocantins, entre outros. As atividades que mais empregam trabalho escravo são a criação de gado, a agricultura em grande escala, o desmatamento e a exploração de carvão ${ }^{103}$.

Destaco que entre o final de 1988 e início de 2000, a Polícia Federal brasileira recebeu denúncias por prática de trabalho análogo ao escravo de várias fazendas no município de Sapucaia, no sul do Estado do Pará, dentre

\footnotetext{
102 Corte IDH, 2016, p. 28.

${ }^{103}$ Ibid., p. 28.
} 
elas, a Fazenda Brasil Verde. Foram inúmeras visitas dos fiscais, especificadamente, em fevereiro de 1989, março de 1993, novembro de 1996, abril e novembro de 1997 e março de 2000.

Diante dessa ineficácia das ações e da falta de aparelhagem do Estado para fiscalização e combate ao trabalho escravo, a Comissão Pastoral da Terra (CPT) e a Diocese de Conceição de Araguaia, acompanhados de José Teodoro da Silva e Miguel Ferreira da Cruz, respectivamente, pai e irmão de Iron Canuto da Silva, de 17 anos, e de Luis Ferreira da Cruz, de 16 anos, apresentaram em dezembro de 1988, uma denúncia perante a Polícia Federal pela prática de trabalho escravo na Fazenda e pelo desaparecimento dos dois jovens.

Na denúncia, informaram que os jovens haviam sido levados por um "gato ${ }^{104 "}$ para trabalhar por um período de 60 dias na Fazenda Brasil Verde. De modo que, ao tentarem abandonar a Fazenda, os adolescentes foram ameaçados e forçados a voltar para a Fazenda e, logo depois, desapareceram. Concomitantemente, um outro trabalhador, que havia escapado da Fazenda relatou por meio de uma outra denúncia que não recebeu nenhum pagamento, passava fome e vivia em condições precárias ${ }^{105}$.

Em 1989, a Polícia Federal realizou uma nova visita à Fazenda Brasil Verde, contudo, o relatório da Polícia Federal só declarou a existência de baixos salários e infrações à legislação trabalhista e negava vestígios de trabalho escravo.

Posteriormente, o Subprocurador Geral da República enviou um relatório ao CPT, aduzindo que justificava a instauração de investigação policial para apuração de eventual prática do delito contra a organização do trabalho e de redução à condição análoga à de escravo. Não obstante, destacou que a maioria dos delitos já haviam prescrevido ${ }^{106}$.

\footnotetext{
${ }^{104}$ São empregados aliciadores da Fazenda.

${ }^{105}$ Corte IDH, 2016, p. 33.

${ }^{106}$ Ibid., p. 35.
} 
Importante destacar que em 1995, a República Brasileira reconheceu a existência e a gravidade do trabalho análogo à escravidão e implantou medidas estruturais de combate ao problema, como, por exemplo, a criação de Grupo de Fiscalização Móvel e a adoção de punições administrativas e criminais a empresas e proprietários.

Em 1996, foi realizada nova fiscalização, com o recém-criado Grupo Móvel do Ministério do Trabalho ${ }^{107}$, o qual verificou a existência de irregularidades relativas à falta de registro dos empregados, contrárias às disposições trabalhistas. Consequentemente, nesse mesmo dia, foi expedido 34 carteiras de trabalho (CTPS).

Em contrapartida, em 1997, José da Costa Oliveira e José Ferreira dos Santos prestaram uma declaração perante o Departamento de Polícia Federal do Pará, Delegacia de Marabá, na qual relataram terem trabalhado e escapado da Fazenda Brasil Verde, aduzindo que os trabalhadores eram ameaçados de morte pelo "gato" ou pelo "fazendeiro e que era prática comum esconder os trabalhadores quando o Ministério do Trabalho realizava fiscalizações.

Após a denúncia, o Grupo Móvel do Ministério do Trabalho realizou uma nova visita, em de abril de 1997, concluindo pelas péssimas condições de trabalho ${ }^{108}$.

Em virtude disso, o Ministério Público Federal apresentou, em 30 de junho de 1997, denúncia ${ }^{109}$ contra Raimundo Alves da Rocha, gato ou

\footnotetext{
107 Grupo de Fiscalização Móvel criado em 1995 com o objetivo de ser instrumento de repressão ao trabalho escravo.

108 Compreendidos em: (i) os trabalhadores se encontravam alojados em barracões cobertos de plástico e palha nos quais havia uma "total falta de higiene"; (ii) vários trabalhadores eram portadores de doenças de pele, não recebiam atenção médica e a água que ingeriam não era apta para o consumo humano; (iii) todos os trabalhadores haviam sofrido ameaças, inclusive com armas de fogo, e (iv) declararam não poder sair da Fazenda. Além disso, comprovou a prática de esconder trabalhadores quando se realizam as fiscalizações. No momento da fiscalização foram encontradas 81 pessoas, aproximadamente 45 dessas 81 pessoas não possuíam carteiras de trabalho e tiveram esse documento emitido naquele momento.

Corte IDH, 2016, p. 34.

${ }^{109}$ A denúncia foi pelos seguintes crimes: Raimundo Alves da Rocha, gato ou empregador de trabalhadores rurais, por trabalho escravo, atentado contra a liberdade do trabalho e aliciamento de trabalhadores; Antônio Alves Vieira, gerente da Fazenda Brasil Verde, por trabalho escravo e atentado contra a liberdade do trabalho e João Luiz Quagliato Neto, proprietário da Fazenda Brasil Verde por frustrar direitos trabalhistas.
} 
empregador de trabalhadores rurais, Antônio Alves Vieira, gerente e João Luiz Quagliato Neto, proprietário da Fazenda Brasil Verde.

Simultaneamente a esse processo penal, a PRT da $8^{\text {a }}$ região instaurou um procedimento administrativo sobre a irregularidade concernente ao tráfico de trabalhadores do interior do Piauí para outros Estados, inclusive para o Estado do Pará110. Em 14 de novembro de 1997, a Delegacia Regional do Trabalho do Pará realizou mais uma fiscalização, mas optou por apenas orientar para que as falhas fossem corrigidas e as normas trabalhistas cumpridas ${ }^{111}$. Posteriormente, a Procuradora do Trabalho solicitou uma nova fiscalização à Fazenda. No entanto, a DRT do Pará respondeu que não pôde realizar por falta de recursos financeiros.

Em 8 de julho de 1998, o Delegado Regional do Trabalho informou que havia sido constatado um "considerável progresso" em relação às irregularidades constatadas na fiscalização anterior.

Em dezembro de 1999, ocorreu a primeira audiência preliminar no processo penal do dono da Fazenda, na qual resultou na suspensão condicional por 2 (dois) anos do processo, a pedido do Ministério Público.

Em fevereiro de 2000, o "gato" conhecido como "Meladinho" aliciou trabalhadores no Município de Barras, Estado do Piauí, para trabalhar na Fazenda Brasil Verde, oferecendo-lhes um bom salário e inclusive um adiantamento. No mês seguinte, dois jovens ${ }^{112}$ fugiram da Fazenda para a Polícia Federal de Marabá, após terem sido maltratados física e verbalmente.

Em 15 de março de 2000, a DRT do Pará realizou uma nova fiscalização na fazenda em conjunto com os agentes da Polícia Federal, em que constatou, novamente, péssimas condições laborativas de trabalho, aliciamento ilegal com promessas de pagamento, barracos e pagamento mínimo e a manifestação unânime dos trabalhadores de "escapar" e retornar

\footnotetext{
${ }^{110}$ Corte IDH, 2016, p. 98.

${ }^{111}$ Ibid., p.137.

112 Testemunhas Antônio Francisco da Silva e Gonçalo Luiz Furtado.
} 
para as suas cidades de origem, onde haviam sido recrutados. Finalmente, a DRT concluiu que existia "trabalho escravo" na Fazenda Brasil Verde ${ }^{113}$.

Em 2001, o juiz federal substituto declarou a "incompetência absoluta da Justiça Federal” para julgar o processo penal do Sr. João Luiz Quagliato, pois os delitos que se investigavam constituíam violações a direitos individuais de um grupo de trabalhadores e não crimes praticados contra a organização do trabalho, de maneira que os autos deveriam ser enviados à justiça estadual de Xinguara, Pará ${ }^{114}$.

Após essa fiscalização, o Ministério do Trabalho interpôs uma Ação Civil Pública contra o proprietário da Fazenda com base no relatório da fiscalização ocorrida em 15 de março de 2000. Desta forma, entendeu o Ministério do Trabalho que João Luiz Quagliato devia “cessar o trabalho escravo, interrompendo os trabalhos forçados e o regime de cárcere privado e jamais praticar novamente o trabalho escravo, por se configurar crime e atentado contra a liberdade do trabalho"115.

Em maio de 2002, o Ministério do Trabalho realizou uma nova fiscalização na Fazenda Brasil Verde e constatou-se que os empregadores vinham cumprindo com seus compromissos e que, "havia eliminado a dependência econômica e física dos trabalhadores aos 'gatos", que era o que causava a exploração de mão de obra forçada e análoga à de escravo ${ }^{116}$.

Passados todos os trâmites do processo penal, somente em novembro de 2004, a Justiça Estadual se declarou incompetente para conhecer do processo penal, o que gerou um conflito de competências. À vista disso, o processo foi encaminhado ao Supremo Tribunal de Justiça (STJ) para solucionar a questão da jurisdição competente, sendo decidido em 2007 que a jurisdição competente era a Federal. Desta maneira, os autos foram enviados à Justiça Federal de Marabá, Pará.

\footnotetext{
${ }^{113}$ Corte IDH, 2016, p. 44.

${ }^{114}$ Ibid., p. 38.

115 Ibid., p. 45.

116 Ibid., p. 46.
} 
Em 10 de julho de 2008, o MP apresentou alegações finais, pedindo a extinção da ação penal do 'gato' e do 'gerente', sob a fundamentação de que não há prova suficiente ${ }^{117}$.

O Juiz Federal do Pará declarou extinta a ação penal, tendo em consideração que havia passado mais de 10 anos desde a apresentação da denúncia ${ }^{118}$.

Diante dos impasses sobre a competência para julgar o crime de prática análogo ao escravo, podemos observar o quanto a morosidade na solução de uma questão preliminar de competência prejudica todo o andamento do processo e, obviamente impede a consecução da justiça, em razão dos acusados serem beneficiados pelo instituto da prescrição, com base no artigo 109 do Código Penal Brasileiro de 1940.

Esta denúncia nos leva a refletir sobre o processo brasileiro de reconhecimento do uso de trabalho na contemporaneidade. Em 1995, o Brasil foi denunciado à Organização dos Estados Americanos (OEA) como um país escravocrata, tendo reconhecido diante das autoridades internacionais a existência de trabalho escravo no país ${ }^{119}$.

Ante o exposto, mesmo que se admita que foi um grande passo o Estado Brasileiro reconhecer a existência de trabalho escravo, estávamos diante de um cenário de diferentes denúncias, sumiços, fiscalizações,

\footnotetext{
${ }^{117}$ Fundamentando pela autoria da prática de delitos de redução a condições análogas à de escravo (art. 149, caput), atentando contra a liberdade de trabalho (art. 197, I) e aliciamento de trabalhadores de um local para outro do território nacional (art. 207), mediante apreensão de dívidas. Por último, aduz que, não obstante a comprovação de autoria e materialidade, os crimes do art. 197, I e 207 do CP, infelizmente, já foram alcançados pela prescrição.

CIDH. Relatório n. ${ }^{\circ}$ 169/11, Caso 12.066. Admissibilidade e Mérito: Fazenda Brasil Verde vs. Brasil. p. 24, Parágrafo 97. Disponível em: <http://www.corteidh.or.cr/mwginternal/de5fs23hu73ds/progress?id=IT5bU4mvW-

VDKV0aXGZqwpQbRJYWYVYaCAUEMnIgSSA>. Acesso em: 16 mai. 2018.

118 [...] pena máxima aplicável era de 8 anos, e que a prescrição da pena era de 12 anos, somente em caso de serem condenados a pena capital não ocorreria a prescrição. $\mathrm{O}$ juiz afirmou que era "muito improvável" que fossem condenados a essa pena, razão pela qual a prescrição era "inevitável." Sobre esse ponto, considerou, que o processo tinha "nascido condenado ao fracasso" e destacou que com os elementos probatórios contidos na instrução criminal o caso era "inútil." Com base nessas considerações, assim como na "falta de a9ao por parte do Estado, na política criminal e na economia processual.

Ibid., p. 98.

${ }^{119}$ ROCHA, Cristina Costa. Trabalhadores da Fazenda Brasil Verde vs; Brasil: trajetórias de luta por justiça de trabalhadores escravizados. p. 358. Disponível em:

<http://wpro.rio.rj.gov.br/revistaagcrj/wp-content/uploads/2016/12/Dossi\%C3\%AA_Artigo-

3.pdf>. Acesso em: 06 jan. 2018.
} 
provas colhidas, mas sem ocorrer uma punição aos responsáveis e uma reparação adequada aos trabalhadores.

No tópico a seguir, veremos as considerações atribuídas ao caso pela $\mathrm{CIDH}$ e as recomendações por ela estabelecidas.

\subsection{Comissão Interamericana de Direitos Humanos}

Nesse contexto, diante da inércia do Estado e considerando as violações de direitos humanos ocorridas na Fazenda Brasil Verde, a Comissão Pastoral da Terra (CPT) e o CEJIL (Centro pela Justiça e o Direito Internacional) ${ }^{120121}$, na qualidade de representantes das vítimas do presente caso e de seus familiares, com base no disposto no artigo 25 (1) e 40 da Convenção Americana sobre Direitos Humanos (CADH) apresentaram em 12 de novembro de 1998, uma denúncia à Comissão Interamericana de Direitos (CIDH) contra o Estado Brasileiro "pela sua omissão e negligência em investigar diligentemente a prática de trabalho escravo na Fazenda Brasil Verde."

Sob a argumentação de que seria um litígio de submissão de diversos trabalhadores a condições análogas à escravidão, trabalho forçado, servidão por dívida e tráfico de pessoas na Fazenda Brasil Verde. Além de tudo, situação essa que se agrava pela falta de diligência estatal em punir os responsáveis, de proceder a uma investigação séria, imparcial e efetiva dos fatos, de oferecer recursos de acesso à justiça às vítimas e repará-las adequadamente $^{122}$.

\footnotetext{
${ }^{120}$ O CEJIL é uma ONG voltada especialmente para o litígio no sistema interamericano e que atualmente representa as vítimas na maior parte dos casos da Corte IDH. É a primeira ONG que atua no sistema interamericano que já surge com caráter regional. A CEJIL teve um papel fundamental de capacitação de quadros de outras ONGS ou de assessoria a ONGs nacionais no procedimentos do sistema interamericano. Ver mais informações sobre o caso no site da CEJIL. CEJIL. Disponível em: <https://cejil.org/en/fazenda-brasil-verde>. Acesso em: 12 mai. 2018.

${ }^{121}$ Para mais informações, ver o site do CEJIL com o acesso ao conhecimento das causas da Comissão e da Corte IDH.

CEJIL. Disponível em: <https://cejil.uwazi.io/pt/entity/j8g5vtqs5zqzd7vi>. Acesso em: 06 jan. 2018.

${ }^{122}$ Escrito de petições, argumento e provas pela CPT e CEJIL perante a Corte IDH. Disponível em: 〈http://www.corteidh.or.cr/docs/casos/trab_hacienda_brasil_verde_br/esap.pdf〉. Acesso em: 06 jan. 2018.
} 
Os peticionários basearam-se pelas violações previstas nos artigos 3 (direito à personalidade jurídica), 4 (direito à vida), 5 (direito à integridade pessoal), 6 (proibição da escravidão, servidão e do tráfico de pessoas), 7 (direito à liberdade pessoal), 8 (garantias judiciais), 11 (proteção da honra e da dignidade), 19 (direitos da criança), 22 (direito de circulação e de residência) e 25 (proteção judicial) da $\mathrm{CADH}$, em relação com o artigo 1.1 e 2 do mesmo instrumento, em prejuízo dos trabalhadores da Fazenda Brasil Verde, conforme os argumentos de fato relatados no tópico anterior.

Segundo o Frei Xavier Plassat, coordenador da Campanha contra o Trabalho Escravo da CPT, a junção de esforços ocorreu uma vez que já existia uma experiência acumulada da CPT com o CEJIL no caso José Pereira. Afirma o coordenador que a Solução Amistosa em 2003 foi considerada um divisor de água pela influência decisiva que teve para o despertar de uma Política Nacional de Erradicação do Trabalho Escravo ${ }^{123}$.

O Relatório de Admissibilidade e Mérito ${ }^{124}$ foi emitido em 03 de novembro de 2011, recebendo o número 169/11 (Caso 12.066) e notificado ao Estado do Brasil mediante comunicação em 4 de janeiro de 2012, na qual foi concedido prazo de dois meses para informar sobre o cumprimento das recomendações.

A CIDH analisou os fatos e os direitos alegados e considerou que essas violações são de responsabilidade internacional do Estado Brasileiro pelo seguinte:

a) Violação dos direitos consagrados nos artigos $6,5,7,22,8$ e 25 da Convenção Americana sobre Direitos Humanos, em relação com o artigo 1.1 da mesma em prejuízo dos trabalhadores da Fazenda Brasil Verde, encontrados nas fiscalizações de 1993, 1996, 1997 e 2000.

b) Violação dos direitos consagrados nos artigos I, II, XIV, VIII, e XVIII da Declaração Americana dos Direitos e Deveres do Homem e, a partir de 15 de setembro de 1992, nos artigos 8 e 25 da Convenção Americana sobre Direitos Humanos em relação com o artigo 1.1 da mesma, em prejuízo de Iron Canuto da

\footnotetext{
${ }^{123}$ PLASSAT, Frei Xavier. Entrevista concedida a Thainá Mamede. 23 maio, 2018.

${ }^{124}$ CIDH, Relatório Relatório n. ${ }^{\circ}$ 169/11, Caso 12.066, 2011. Disponível em:

$\langle$ http://www.corteidh.or.cr/docs/casos/trab_hacienda_brasil_verde_br/sometim_port.pdf $>$. Acesso em: 16 maio. 2018.
} 
Silva e Luis Ferreira da Cruz e de seus familiares, inclusive José Teodoro da Silva e Miguel Ferreira da Cruz. Além disso, violação do artigo I da Declaração Americana e, a partir de 25 de setembro de 1992, do artigo 5 da Convenção Americana em prejuízo dos familiares de Iron Canuto da Silva e Luis Ferreira da Cruz.

c) Violação dos artigos I, VII e XIV da Declaração Americana e, partir de 25 de setembro de 1992, dos artigos 7,5,4,5,19 da Convenção Americana em relação com os artigos 8,25 e 1.1 da mesma, em prejuízo de Iron Canuto da Silva e Luis Ferreira da Cruz.

d) Não adoção de medidas suficientes e eficazes para garantir sem discriminação os direitos dos trabalhadores encontrados nas fiscalizações de 1993, 1996, 1997 e 2000, em conformidade com o artigo 1.1 da Convenção, em relação com os direitos reconhecidos nos artigos 6,5,7,22, 8 e 25 da mesma.

e) Não adoção de medidas em conformidade com o artigo II da Declaração Americana, em relação com o artigo XVIII da mesma e, a partir de 25 de setembro de 1992, com o artigo 1.1 da Convenção, em relação com os direitos reconhecidos nos artigos 8 a 25 da mesma em prejuízo dos trabalhadores Iron Canuto da Silva, Luis Ferreira da Cruz, Adailton Martins dos Reis e José Soriano da Costa, bem como dos familiares dos dois primeiros, entre os quais figuram José Teodoro da Silva e Miguel Ferreira da Cruz.

f) A aplicação da figura de prescrição no presente caso em violação dos artigos 8.1 e 25.1, em relação com as obrigações estabelecidas no artigo 1.1 e no artigo 2 do mesmo instrumento, em prejuízo dos trabalhadores Iron Canuto da Silva e Luis Ferreira da Cruz, Adailton Martins dos Reis e José Soriano da Costa, José Teodoro da Silva e Miguel Ferreira da Cruz, bem como dos trabalhadores que estavam na Fazenda Brasil Verde durante as fiscalizações de 1997.

Ao final, a Comissão apresentou as seguintes recomendações ao Brasil $^{125}$ :

1. Reparar adequadamente as violações de direitos declaradas no presente relatório tanto no aspecto material como no moral. Em especial, o Estado deve assegurar que sejam restituídos às vítimas os salários devidos pelo trabalho realizado, assim como as quantias de dinheiro ilegalmente subtraídas deles. Se for necessário, essa restituição poderá ser feita a partir do lucro ilegal dos proprietários da fazenda.

2. Levar a cabo uma investigação dos fatos relacionados com as violações de direitos humanos declaradas no presente relatório em relação com o trabalho escravo, e conduzir as investigações de maneira imparcial efetiva e dentro de um

${ }^{125}$ CIDH, 2011, Parágrafo 265. 
prazo razoável com o objetivo de esclarecer os fatos de forma completa, identificar os responsáveis e impor as sanções correspondentes.

3. Levar a cabo uma investigação dos fatos relacionados com o desaparecimento de Iron Canuto da Silva e Luis Ferreira da Cruz, e conduzir as investigações de maneira imparcial, efetiva e dentro de um prazo razoável com o objetivo de esclarecer os fatos de forma completa, identificar os responsáveis e impor as sanções correspondentes.

4. Dispor as medidas administrativas, disciplinares ou penais correspondentes diante das ações e omissões dos funcionários estatais que contribuíram para a denegação de justiça e impunidade em que se encontram os fatos do caso. Nesse sentido, deve-se colocar especial ênfase em que foram abertos processos administrativos e não penais para a investigação de desaparecimentos; que se iniciaram processos administrativos e laborais para a investigação de trabalho escravo, e que a única investigação penal aberta em relação com esse crime prescreveu;

5. Estabelecer um mecanismo que facilite a localização das vítimas de trabalho escravo da visita de 1989 e das fiscalizações de 1996, 1997 e 2000, a identificação e localização das vítimas de trabalho escravo da fiscalização de 1993, assim como de Iron Canuto da Silva, Luis Ferreira da Cruz, Adailton Martins dos Reis, José Soriano da Costa e dos familiares dos dois primeiros, José Teodoro da Silva e Miguel Ferreira da Cruz, a fim de compensá-los.

6. Continuar implementando políticas públicas, assim como medidas legislativas e de outra índole para a erradicação de trabalho escravo. Em especial, o Estado deve monitorar a aplicação e a sanção de pessoas responsáveis por trabalho escravo, em todos os níveis.

7. Fortalecer o sistema legal e criar mecanismos de coordenação entre a jurisdição penal e jurisdição laboral para superar as lacunas que se produzem na investigação, persecução a sanção das pessoas responsáveis pelos delitos de servidão e trabalho forçado.

8. Velar pelo estrito cumprimento das leis laborais relativas a jornadas de trabalho e pagamento em igualdade com os demais trabalhadores assalariados.

9. Adotar as medidas necessárias para erradicar de todo tipo de discriminação racial, particularmente realizar campanhas de promoção para conscientizar a população nacional e os funcionários do Estado - inclusive os operadores de justiça - sobre a discriminação e a sujeição à servidão e ao trabalho forçado.

Após a concessão de 10 prorrogações, o Estado não avançou no cumprimento das medidas estipuladas no relatório, muito menos na reparação adequada às vítimas nos aspectos tanto morais como materiais, 
tampouco apresentou informação sobre medidas para cumprir as investigações dos fatos do caso, embora o Estado tenha apresentado amplas informações sobre a normativa e as políticas públicas sobre a matéria ${ }^{126}$.

Em março de 2015, a Comissão submeteu o caso à jurisdição da Corte IDH, com base no disposto pelo artigo 46.2 da CADH, destacando a situação de trabalho forçado e servidão por dívidas vividas por milhares de trabalhadores, isto é, formas contemporâneas de escravidão. Desta forma, visando alcançar meios adequados de sancionamento, prevenção e erradicação dessas práticas e, por óbvio, o desenvolvimento de uma jurisprudência sobre trabalho escravo contemporâneo.

É válido destacar que a CIDH somente submeteu à Corte as ações e omissões estatais que ocorreram, ou continuaram ocorrendo posteriormente a 10 de dezembro de 1998, data de aceitação da competência da Corte pelo Estado, em conformidade ao artigo 62 da CADH. Portanto, os fatos narrados de agora em diante estão dentro da competência temporal da Corte.

\subsection{Corte Interamericana de Direitos Humanos}

No tópico anterior, analisamos os fatos e o processo durante a Comissão até a submissão do caso a Corte IDH. Primeiramente, é necessário relembrar que a Corte só pôde conhecer do caso, uma vez que foram esgotados os processos previstos nos artigos 48 a 50 da Convenção Americana.

A Corte IDH foi acionada para resolver a controvérsia acerca da interpretação e/ou aplicação da própria convenção ao caso em concreto, legitimando a sua competência contenciosa com caráter jurisdicional.

Quanto ao procedimento perante a Corte, o Estado brasileiro e seus representantes foram notificados da apresentação do caso pela Comissão em

\footnotetext{
${ }^{126}$ Ofício de submissão do caso à Corte. Disponível em: <https://www.oas.org/es/cidh/decisiones/corte/2015/12066NdeResPT.pdf>. Acesso em: 15 mar. 2018.
} 
14 de abril de 2015. Os representantes das vítimas apresentaram um escrito de petições, argumentos e provas nos termos dos artigos 25 e 40 do Regulamento da Corte. Enquanto que, o Estado apresentou contestação, com 10 exceções preliminares à submissão do caso à Corte, nos termos do artigo 41 do Regimento do Tribunal. Em outubro, os representantes e a Comissão apresentaram suas observações às exceções preliminares suscitadas pelo Estado.

Neste ínterim, as partes e a Comissão foram convocadas para uma audiência pública, a qual foi celebrada em 18 e 19 de fevereiro de 2016, durante o $113^{\circ}$ Período Ordinário de Sessões da Corte. Durante a audiência foram recebidas as declarações de duas testemunhas propostas pelos representantes e quatro peritos propostos pela Comissão, pelos representantes e pelo Estado, além das observações e alegações finais orais, respectivamente, da Comissão, dos representantes e do Estado ${ }^{127}$.

Por oportuno, pontuo que o Tribunal recebeu sete escritos de amicus curiae $^{128}$.

Diante da complexidade dos pontos controvertidos do caso em comento e em razão da necessidade de obtenção de provas específicas para solução da controvérsia, ficou acordado pelo pleno da Corte e em aplicação do artigo 58.a) e 58 d) do Regulamento, a realização de uma diligência in situ à República Federativa do Brasil entre os dia 6 e 7 de junho de 2016, visando colher as declarações de cinco supostas vítimas do presente caso e também, a título informativo, de cinco funcionários estatais responsáveis pela erradicação da escravidão no Brasil.

Por último, no dia 28 de junho de 2016, a Comissão remeteu as suas observações finais escritas, tal como as alegações finais pelos

\footnotetext{
${ }^{127}$ Corte IDH, 2016, p. 7.

128 Clínica de Direitos Humanos da Amazónia, Universidade Federal do Pará; Instituto de Democracia e Direitos Humanos da Pontifícia Universidade Católica do Peru; International Trade Union Confederation; Universidade do Norte da Colômbia; Human Rights in Pratice; Tara Melish, professora Associada da State University of New York e Buniness na Human Right Project, University of Essex.
} 
representantes e pelo Estado. Assim, a Corte pôde iniciar a deliberação da sentença em 18 de outubro de 2016.

\subsubsection{Fundamentação jurídica da decisão}

Primeiramente, neste tópico será abordado as exceções preliminares suscitadas pelo Estado para não submissão do caso à Corte. Após, iniciaremos o estudo do mérito analisado pela Corte.

O Estado em seu escrito de contestação, apresentou 10 exceções preliminares $^{129}$. A Corte declarou parcialmente procedente a exceção preliminar interposta pelo Estado relativa à incompetência ratione temporis sobre os fatos anteriores à data de reconhecimento da jurisdição da Corte por parte do Estado e a incompetência ratione temporis em relação a fatos anteriores à adesão do Estado à Convenção Americana ${ }^{130}$.

Em contrapartida, desconsiderou as demais exceções preliminares interpostas pelo Brasil. Destarte, decidiu pela análise de dois grupos de fatos: as ações e omissões a partir de 10 de dezembro de 1998 na investigação e nos processos relacionados à inspeção realizada na Fazenda Brasil Verde no ano de 1997; e os fatos violatórios e a respectiva investigação e processos decorrentes da inspeção realizada em 15 de março de 2000 à referida Fazenda ${ }^{131}$.

\footnotetext{
${ }^{129}$ Exceções apresentadas pelo Estado: (i) a inadmissibilidade da submissão do caso à Corte em virtude da publicação do Relatório de Mérito por parte da Comissão; (ii) a incompetência ratione personae a respeito de supostas vítimas não identificadas, aquelas identificadas mas que não outorgaram procuração, que não figuravam no Relatório de Mérito da Comissão ou que não estavam relacionadas aos fatos do caso; (iii) a incompetência ratione personae sobre violações em abstrato; (iv) dois pedidos de incompetência ratione temporis sobre fatos anteriores à data de reconhecimento da jurisdição da Corte por parte do Estado; (v) incompetência ratione materiae por violação ao princípio da subsidiariedade do Sistema Interamericano; (vi) incompetência ratione materiae relativa a supostas violações à proibição de tráfico de pessoas; (vii) a incompetência ratione materiae sobre supostas violações de direitos trabalhistas; (viii) a falta de esgotamento prévio de recursos internos e (ix) a prescrição da petição perante a Comissão em relação às pretensões de reparação de dano moral e material.

Corte IDH, 2016, p. 9.

${ }^{130}$ CONATRAE. Trabalho Escravo: Condenação do Brasil pela Corte Interamericana de Direitos Humanos no caso Fazenda Brasil Verde. Brasília, 2017. p. 37-40. Disponível em: <https://www.dropbox.com/s/2ow5tdoqmzmd9lc/LIVRO\%20DA\%20CONATRAE\%20\%20\%27 TRABALHO $\% 20$ ESCRAVO $\% 20-$ \%20SENTEN\%C3\%87A\%20BRASIL\%20VERDE\%27.pdf?dl=0>. Acesso em: 21 abr. 2018. ${ }^{131}$ Ibid., p. 16-17.
} 
No que diz respeito ao mérito, a Corte em sua sentença dividiu os tópicos nos argumentos da Comissão, dos representantes das supostas vítimas e do Estado sobre as alegadas violações estabelecidas nos artigos 6, 5, 7, 3, 11 e 22 da Convenção Americana. Em seguida, na análise do mérito, respondeu aos questionamentos sobre: (i) o alcance do artigo 6 da Convenção Americana de acordo com o Direito Internacional dos Direitos Humanos e as figuras de escravidão, trabalho forçado, servidão e tráfico de pessoas; (ii) a aplicação do artigo aos fatos do caso e (iii) a responsabilidade do Estado.

Destaca a Corte que trata de um primeiro caso contencioso perante o Tribunal Interamericano substancialmente relacionado com o inciso 1 do artigo $6^{132}$. Por essa razão, a Corte decidiu fazer um breve resumo da evolução da matéria no âmbito do Direito Internacional, de modo a contextualizar todos os conceitos enquadrados na escravidão, servidão, tráfico de escravos e mulheres e trabalho forçado, a luz das normas gerais de interpretação previstas no artigo 29 da CADH.

Outro ponto que merece destaque da sentença é afirmação de que os tratados de direitos humanos são instrumentos vivos, a qual a interpretação deve ser também evolutiva ao tempo e as condições de vida atuais. Para isso, foi utilizado a Convenção de Viena sobre o Direitos dos Tratados, norma esta que reflete a regra geral e consuetudinária de interpretação dos tratados internacionais.

Nesse sentido, a Corte afirmou que o direito a não ser submetido a escravidão, servidão, trabalho forçado ou tráfico de pessoas possui um caráter essencial não apenas ao disposto no artigo 27.2 Convenção Americana ${ }^{133}$, como também em vários outros tratados internacionais ${ }^{134}$.

\footnotetext{
${ }^{132}$ Corte IDH, 2016, p. 63.

${ }^{133}$ Ibid., p. 63.

134 Declaração Universal de Direitos Humanos de 1948 (art. 4), Convenção Suplementar sobre a Abolição da Escravatura, 1956 (art. 1); Pacto Internacional de Direitos Civis e Políticos, 1966, (art. 8); Convenção Europeia de Direitos do Homem, 1950, (art. 4); Estatuto de Roma da Corte Penal Internacional, 1998 (art. 7); Convenção no 182 da Organização Internacional do Trabalho, 1999 (art. 3); Carta Africana de Direitos Humanos e dos Povos, 1981 (art. 5); Convenção Americana sobre Direitos Humanos, 1969 (art. 6.).
} 
Além disso, constatou que a proibição da escravidão está prevista no artigo 6.1 da Convenção Americana e reafirmou que consiste em uma norma imperativa do Direito Internacional (jus cogens) e implica em obrigações erga omnes, isto é, obrigações impostas a todos os Estados independentemente de aceitação e de objeção contra elas. Além do mais, tanto o Brasil como a maioria dos Estados da região são parte dos principais tratados internacionais sobre esse tema específico: a Convenção sobre a Escravatura de 1926 e a Convenção Suplementar sobre a Abolição da Escravatura de 1956.

No decorrer da sentença, a Corte fez um resumo ${ }^{135}$ dos dispositivos relevantes dos instrumentos internacionais e das decisões de tribunais internacionais e de órgãos quase judiciais sobre o delito internacional de escravidão.

Uma vez desenvolvidos os conceitos extraídos de cada instrumento presente no Direito Internacional e da proibição estabelecida no artigo 6 da Convenção Americana sobre Direitos Humanos, a Corte frisou que este conceito evoluiu e não mais se limita à propriedade sobre a pessoa. Portanto, passou a considerar que há dois elementos fundamentais para definir uma situação de escravidão ${ }^{136}$.

O primeiro elemento (estado ou condição) se refere tanto à situação de jure como de facto, isto é, não é essencial a existência de um documento formal ou de uma norma jurídica para a caracterização desse fenômeno, como no caso da escravidão chattel $^{137}$ ou tradicional.

Assim, no âmbito da escravidão, o elemento de "propriedade" deve ser entendido como "posse", melhor dizendo, uma demonstração de controle sobre outra pessoa. Logo, "no momento de determinar o nível de controle requerido para considerar um ato como escravidão, poder-se-ia

\footnotetext{
${ }^{135}$ Resumo localizado nos itens 248-268 (pontos B1 e B2).

${ }^{136}$ Corte IDH, 2016, p. 71.

${ }^{137}$ A chamada escravidão 'chattel' corresponde ao que se compreendia como 'escravidão do bem móvel', para fazer referência à escravidão clássica ou escravidão de direito, na qual, uma pessoa pertencia legalmente a outra.
} 
equipará-lo à perda da própria vontade ou a uma diminuição considerável da autonomia pessoal"138.

Nesse sentido, o segundo elemento seria o chamado "exercício de atributos da propriedade", na qual deve ser entendido nos dias atuais como o controle exercido sobre uma pessoa que lhe restrinja ou prive significativamente de sua liberdade individual, com intenção de exploração mediante o uso, a gestão, o benefício, a transferência ou o despojamento de uma pessoa. Em geral, este exercício se apoiará e será obtido através de meios tais como a violência, fraude e/ou a coação ${ }^{139}$.

Com esse fim, a Corte orientou que para análise da situação de escravidão nos dias atuais, deve-se averiguar a manifestação dos chamados "atributos do direito de propriedade", nos seguintes elementos ${ }^{140}$ : restrição ou controle da autonomia individual; (ii) perda ou restrição da liberdade de movimento de uma pessoa; (iii) obtenção de um benefício por parte do perpetrador; (iv) ausência de consentimento ou de livre arbítrio da vítima, ou sua impossibilidade ou irrelevância devido à ameaça de uso da violência ou outras formas de coerção, o medo de violência, fraude ou falsas promessas; (v) uso de violência física ou psicológica; (vi) posição de vulnerabilidade da vítima; (vii) detenção ou cativeiro e (viii) exploração.

No que corresponde à servidão, a Corte coincide com a definição do Tribunal Europeu de Direitos Humanos, ponderando que essa expressão do artigo 6.1 da Convenção deve ser interpretada como "a obrigação de realizar trabalho para outros, impostos por meio de coerção, e a obrigação de viver na propriedade de outra pessoa, sem a possibilidade de alterar essa condição".

Tal entendimento sobre a servidão corresponde a uma forma análoga de escravidão e deve receber a mesma proteção e obrigação que a escravidão em sua forma tradicional, isto é, proibição absoluta. Assim, com

\footnotetext{
${ }^{138}$ Corte IDH, 2016, p. 72.

${ }^{139}$ Ibid., p. 72.

${ }^{140}$ Ibid., p. 72.
} 
efeito, a Convenção Suplementar de 1956 definiu as formas análogas à escravidão como servidão, servidão por dívidas, entre outras formas.

Sabemos que a Convenção Americana proíbe tanto o tráfico de escravos como o tráfico de mulheres "em todas as suas formas", de maneira que a Corte interpreta essa proibição de forma ampla e sujeita às precisões de sua definição de acordo com seu desenvolvimento no Direito Internacional.

Desse modo, o Tribunal faz um apanhado de conceitos incluídos nos tratados internacionais e de interpretações realizadas por outros tribunais internacionais de direitos humanos do que seriam as definições sobre tráfico de escravos como tráfico de mulheres. Da mesma maneira, relata que o elemento que vincula as proibições de tráfico de escravos e mulheres são os mesmos, posto que é o controle exercido pelos perpetradores sobre as vítimas durante o transporte ou translado com fim de exploração.

Destaca o principal tratado internacional especializado sobre o tráfico de pessoas, o Protocolo Relativo à Prevenção, Repressão e Punição do Tráfico de Pessoas, em Especial Mulheres e Crianças da Convenção das Nações Unidas contra o Crime Organizado Transnacional (doravante denominado "Protocolo de Palermo"), do ano 2000, na qual afirma a proibição do tráfico de pessoas em seu artigo 4.

A Corte Interamericana também considera que, à luz do desenvolvimento ocorrido no Direito Internacional nas últimas décadas, a expressão "tráfico de escravos e de mulheres" do artigo 6.1 da Convenção Americana deve ser interpretada de maneira ampla para referir-se ao “tráfico de pessoas", tencionando a ótica da interpretação mais favorável ao ser humano e do princípio pro personae.

Outrossim, identifica alguns elementos comuns a ambas as formas de tráfico, relativas ao: (i) o controle de movimento ou do ambiente físico da pessoa; ii) o controle psicológico; iii) a adoção de medidas para impedir a fuga; e iv) o trabalho forçado ou obrigatório, incluindo a prostituição. 
Portanto, a proibição do "tráfico de escravos e o tráfico de mulheres", contida no artigo 6.1 da Convenção Americana, refere-se a: i) o recrutamento, o transporte, a transferência, o alojamento ou o acolhimento de pessoas; ii) ameaça ou ao uso da força ou outras formas de coação, ao rapto, à fraude, ao engano, ao abuso de autoridade ou à uma situação de vulnerabilidade ou à entrega ou aceitação de pagamentos ou benefícios, para obter o consentimento de uma pessoa a fim de que se tenha autoridade sobre ela. Para os menores de 18 anos estes requisitos não são condição necessária para a caracterização de tráfico; iii) com qualquer fim de exploração.

Acerca do trabalho forçado ou obrigatório, ato proibido expressamente pelo artigo 6.2 da Convenção Americana, a Corte reafirma que já se manifestou sobre o conteúdo e alcance desta norma no Caso dos Massacres de Ituango Vs. Colômbia. No presente caso, ficou estabelecido que a definição de trabalho forçado está prevista no artigo 2.1 da Convenção n. ${ }^{\circ} 29$ da OIT, a qual dispõe:

[a] expressão "trabalho forçado ou obrigatório" designará todo trabalho ou serviço exigido de um indivíduo sob ameaça de qualquer penalidade e para o qual ele não se ofereceu de espontânea vontade.

Além disso, fixou os dois elementos básicos para definição de trabalho forçado ou obrigatório, qual seja: (i) trabalho ou serviço sejam exigidos "sob a ameaça de uma pena" e; (ii) que sejam realizados de forma involuntária ${ }^{141}$. Ao final daquele caso, o Tribunal considerou que, para a cauterização de uma violação fosse atribuída aos agentes do Estado, deveria ser por meio de sua participação direta ou por sua aquiescência em relação aos fatos ${ }^{142}$.

\footnotetext{
${ }^{141}$ Corte IDH, 2016, p. 77.

${ }^{142}$ Ibid., p. 77.
} 


\subsubsection{Decisão dos fatos e as reparações}

Após todo o exposto, a Corte analisou os fatos do caso em concreto para averiguar se as violações sofridas pelas supostas vítimas na Fazenda Brasil Verde correspondem a alguns dos cenários expostos no tópico anterior.

Salientou ser fato incontroverso a evolução histórica do fenômeno da escravidão no Brasil, em particular no ambiente rural, como também as denúncias realizadas pela CPT sobre as ocorrências de trabalho escravo nas regiões norte e nordeste do país. Finalmente, a Corte considerou que não há controvérsia que a submissão foi realizada por terceiros particulares e não por agentes estatais.

A Corte enfatizou a existência de um mecanismo de aliciamento de trabalhadores através de fraudes e enganos. Ademais, reconheceu que os fatos do caso indicam a existência de uma situação de servidão por dívida, visto que os trabalhadores recebiam o adiantamento em dinheiro por parte do gato, a existência de salário irrisório. descontos por comida, medicamentos e outros produtos, originando uma dívida impagável.

Além disso, os juízes reconheceram ainda que os trabalhadores não tinham perspectiva de sair daquela situação degradante, em virtude da presença de guardas armados, a restrição de saída sem o pagamento da dívida, coação física e psicológica por parte dos 'gatos', guardas de segurança e até mesmo, o medo de represárias ou medo de morrerem na mata na fuga.

A Corte acentuou que existia ainda um agravante decorrente da condição de vulnerabilidade dos trabalhadores, os quais eram, em sua maioria, analfabetos, provenientes de uma região muito distante do país, não conheciam os arredores da Fazenda Brasil Verde e estavam submetidos a condições desumanas de vida.

Diante do exposto, restou evidente para a Corte que os trabalhadores resgatados da Fazenda Brasil Verde se encontravam em uma situação de servidão por dívida e de submissão a trabalhos forçados. Sem prejuízo do 
anterior, o Tribunal considerou que as características específicas a que foram submetidos os 85 trabalhadores resgatados em 15 de março de 2000 ultrapassavam os elementos da servidão por dívida e de trabalho forçado, para atingir e cumprir os elementos mais estritos da definição de escravidão estabelecida pela Corte (par. 272 supra), em particular o exercício de controle como manifestação do direito de propriedade ${ }^{143}$.

Nesse sentido, a Corte constatou que: i) os trabalhadores se encontravam submetidos ao efetivo controle dos gatos, gerentes, guardas armados da fazenda, e, em última análise, também de seu proprietário; ii) de forma tal que sua autonomia e liberdade individuais estavam restringidas; iii) sem seu livre consentimento; iv) através de ameaças, violência física e psicológica, v) para explorar seu trabalho forçado em condições desumanas. Além disso, as circunstâncias da fuga realizada pelos senhores Antônio Francisco da Silva e Gonçalo Luiz Furtado e os riscos enfrentados até denunciarem o ocorrido à Polícia Federal demonstram: vi) a vulnerabilidade dos trabalhadores e vii) o ambiente de coação existente nesta fazenda, os quais viii) não lhes permitiam alterar sua situação e recuperar sua liberdade. Por todo o exposto, a Corte conclui que a circunstância verificada na Fazenda Brasil Verde em março de 2000 representava uma situação de escravidão ${ }^{144}$.

Outro aspecto interessante verificado pela Corte foi o entendimento de que os trabalhadores haviam sido vítimas de tráfico de pessoas, tendo como fundamento o contexto da captação ou aliciamento de trabalhadores através de fraude, enganos e falsas promessas, bem como a declaração pericial da Procuradora Federal Raquel Elias Dodge na audiência pública, "fichas de entrevistas" dos trabalhadores resgatados na fiscalização de março de 2000, as denúncias de Antônio Francisco da Silva e Gonçalo Luiz Furtado que deram origem à referida fiscalização e testemunhos de Marcos

\footnotetext{
${ }^{143}$ Corte IDH, 2016, p. 79.

${ }^{144}$ Ibid., p. 79.
} 
Antônio Lima, Francisco Fabiano Leandro, Rogerio Felix Silva e Francisco das Chagas Bastos Sousa, durante a diligência in situ do presente caso.

Portanto, trata-se de um caso de violações de vários direitos individualmente, no entanto, a Corte interpretou que não é necessário fazer um pronunciamento individual a respeito de todos os direitos alegados pelos representantes, uma vez considerado caráter pluriofensivo da escravidão.

Explanou que a submissão de uma pessoa a esta condição, são violados vários direitos individualmente, alguns em maior ou menor intensidade, dependendo das circunstâncias fáticas específicas de cada caso. Asseverou também que na análise fática do caso, constatou a violação à integridade e à liberdade pessoais (violência e ameaças de violência, coerção física e psicológica dos trabalhadores, restrições da liberdade de movimento), os tratamentos indignos (condições degradantes de habitação, alimentação e de trabalho) e a limitação da liberdade de circulação (restrição de circulação em razão de dívidas e do trabalho forçado exigido).

Posteriormente, a Corte fez algumas considerações sobre a legislação brasileira, em virtude da alegação utilizada pelo Brasil de que a situação identificada na Fazenda Brasil Verde seria apenas de violações a direitos trabalhistas, na qual poderia até ser classificada como um delito, mas não como escravidão.

Destaca a Corte que a interpretação da proibição da escravidão no artigo 149 do Código Penal, em sua redação original, exigia a ocorrência de uma restrição de liberdade das vítimas, fato comprovado nos autos, em virtude das ameaças, da violência e servidão por dívida existente na Fazenda Brasil Verde, bem como foi constatado a existência de trabalho exaustivo, falsificação de documentos, menores de idade e situações degradantes de trabalho.

Outro argumento utilizado pela Corte diz respeito ao fato de que se o país adota normas mais protetoras à pessoa humana desde 2003. Desta feita, é inconcebível que o Tribunal deva restringir sua proteção para uma norma 
menos protetiva porque isso seria uma violação ao próprio artigo 29 da $\mathrm{CADH}$.

Ademais, o entendimento adotado no artigo citado é utilizar uma interpretação pro personae, na qual exige que a Corte interprete os direitos humanos previstos no $\mathrm{CADH}$ à luz da norma mais protetora àquelas pessoas.

Além disso, a Corte reconheceu as jurisprudências recentes do Tribunal Superior do Trabalho e do STF no Recurso Especial 459510/MT ${ }^{145}$, onde o voto da Ministra Rosa Weber expôs que para ser considerado situação análoga à escravidão, não basta uma mera violação à legislação trabalhista, e sim que as violações sejam graves, persistentes e que cheguem a afetar a livre determinação da vítima.

O Corte IDH determinou que os Estados têm a obrigação de garantir a criação das condições necessárias para que não ocorram violações a esse direito inalienável e, em particular, o dever de impedir que seus agentes e terceiros particulares atentem contra ele. A observância do artigo 6, relacionado ao artigo 1.1 da Convenção Americana, não apenas pressupõe que nenhuma pessoa seja submetida a escravidão, servidão, tráfico ou trabalho forçado, mas também requer que os Estados adotem todas as medidas apropriadas para pôr fim a estas práticas e prevenir a violação do direito a não ser submetido a essas condições, em conformidade com o dever de garantir o pleno e livre exercício dos direitos de todas as pessoas sob sua jurisdição ${ }^{146}$.

A Corte certificou que apesar do Estado ter pleno conhecimento da submissão dos trabalhadores à escravidão ou trabalho forçado no Estado do Pará, não demonstrou ter adotado medidas específicas de para prevenir a

\footnotetext{
145 Trecho do voto da Ministra: Por óbvio, nem toda violação dos direitos trabalhistas configura trabalho escravo. Contudo, se a afronta aos direitos assegurados pela legislação regente do trabalho é intensa e persistente, se atinge níveis gritantes e se os trabalhadores são submetidos a trabalhos forçados, jornadas exaustivas ou a condições degradantes, é possível, em tese, o enquadramento no crime do art. 149 do Código Penal, pois conferido aos trabalhadores tratamento análogo ao de escravos, com a privação de sua liberdade e, sobretudo, de sua dignidade, mesmo na ausência de coação direta contra a liberdade de ir e vir.

Corte IDH, 2016, p. 82.

${ }^{146}$ Ibid., p. 83.
} 
ocorrência ao artigo 6.1 da Convenção, expondo os trabalhadores às condições degradantes e desumanas identificadas.

A Corte, de maneira muito delicada, reconheceu a vulnerabilidade destes trabalhadores, em virtude da discriminação em razão da posição econômica à qual estavam submetidos. Desta forma, incluiu violação ao artigo 24 da $\mathrm{CADH}$.

Nesse sentido, a Corte recordou que, à medida em que a obrigação geral do artigo 1.1 se refere ao dever do Estado de respeitar e garantir, "sem discriminação", os direitos contidos na Convenção Americana, o artigo 24 protege o direito à "igual proteção da lei”. Isto é, o artigo 24 da Convenção Americana proíbe a discriminação de direito ou de fato, não apenas quanto aos direitos contidos neste tratado, mas no que respeita a todas as leis promulgadas pelo Estado e sua aplicação ${ }^{147}$.

Em outra perspectiva, a Corte pronunciou no sentido de estabelecer que toda pessoa que se encontre em uma situação de vulnerabilidade é titular de uma proteção especial, em razão dos deveres especiais cujo cumprimento por parte do Estado é necessário para satisfazer as obrigações gerais de respeito e garantia dos direitos humanos. $\mathrm{O}$ Tribunal rememorou que, não basta que os Estados se abstenham de violar os direitos, mas é imperativa a adoção de medidas positivas, determináveis em função das particulares necessidades de proteção do sujeito de direito, seja por sua condição pessoal ou pela situação específica em que se encontre, como a extrema pobreza ou a marginalização ${ }^{148}$.

Consequentemente, incorre em responsabilidade internacional nesses casos em que existindo discriminação estrutural, o Estado não adota medidas específicas de modo a alterar a vulnerabilidade daqueles grupos de pessoas que foram aliciadas para trabalharem na Fazenda Brasil Verde. Razão pela qual, a Corte verificou que a falta de ação e de sanção dos fatos é explicada através de uma normalização das condições dessas pessoas, em

\footnotetext{
${ }^{147}$ Corte IDH, 2016, p. 87.

${ }^{148}$ Ibid., p. 88.
} 
sua maioria, com características mais pobres. Por conseguinte, o Estado viola o direito a proteção judicial, prevista no artigo 25 da Convenção Americana, em relação aos artigos 1.1 e 2 do mesmo instrumento.

Afirmou que de acordo com vários relatórios da OIT e do Ministério do Trabalho do Brasil, "a situação de miséria do obreiro é o que o leva espontaneamente à aceitação das condições de trabalho propostas", toda vez que "quanto piores as condições de vida, mais dispostos estarão os trabalhadores a correrem os riscos do trabalho longe de casa. A pobreza, nesse sentido, é o principal fator da escravidão contemporânea no Brasil, por aumentar a vulnerabilidade de significativa parcela da população, tornando-a presa fácil dos aliciadores para o trabalho escravo" 149 .

A conclusão do Tribunal baseou-se no período entre a denúncia e a fiscalização, em março de 2000, o Estado não conseguiu coordenar a participação da Polícia Federal ativamente na referida fiscalização, além da função de proteção da equipe do Ministério do Trabalho. Além disso, o Estado não atuou com a devida diligência para prevenir adequadamente a forma contemporânea de escravidão constatada no presente caso e não buscou, de acordo com as circunstâncias do caso, por fim a esse tipo de violação ${ }^{150}$. Em suma, o Estado não atuou com diligência para prevenir e erradicar a forma contemporânea de escravidão, violando o caráter de jus cogens da proibição.

As atuações analisadas pela Corte foram a partir de dezembro de 1998, nas seguintes ações: (i) no processo penal n. ${ }^{\circ} 1997.39 .01 .831-3$ e na Ação Civil Pública, iniciada em 1997, com respeito à fiscalização de 10 de março de 1997 e (ii) os processos iniciados em virtude da fiscalização de 15 de março de 2000. E concluiu, que o Estado violou a garantia judicial de devida diligência e garantia judicial do prazo razoável, previstas no art. 8.1 da Convenção Americana, em relação ao artigo 1.1 do mesmo instrumento,

\footnotetext{
${ }^{149}$ Corte IDH, 2016, p. 89.

150 Corte IDH. Resumo oficial emitido pela Corte IDH. p. 7, parágrafo 3. Disponível em: <http://www.corteidh.or.cr/docs/casos/articulos/resumen_318_por.pdf>. Acesso em: 05 mai. 2018.
} 
em prejuízo dos 43 trabalhadores resgatados durante a fiscalização de 23 de abril de 1997, identificadas pela Corte.

A Corte advertiu que nenhum dos procedimentos a respeito dos quais recebeu informação determinou qualquer tipo de responsabilidade em relação às condutas denunciadas, de maneira que não constituíram meios para obter a reparação de danos às vítimas, pois em nenhum dos processos foi realizado um estudo de mérito de cada questão proposta ${ }^{151}$.

De igual modo, a Corte decretou que a prescrição dos delitos de submissão à condição de escravo e suas formas análogas é incompatível com a obrigação do Estado brasileiro de adaptar sua normativa interna de acordo aos padrões internacionais. Assim, decidiu que, no presente caso, a aplicação da prescrição constituiu um obstáculo para a investigação dos fatos, para a determinação e punição dos responsáveis e para a reparação das vítimas, apesar do caráter de delito de Direito Internacional que os fatos denunciados representavam ${ }^{152}$.

Em razão do exposto, os juízes reconheceram que o Estado violou o direito a não ser submetido à escravidão e ao tráfico de pessoas, previsto no artigo 6.1 da Convenção Americana, em relação aos artigos 1.1, 3, 5, 7, 8, 11 e 22, 25 do mesmo instrumento, em prejuízo dos 85 trabalhadores resgatados em 15 de março de 2000 na Fazenda Brasil Verde. Por sua vez, a Corte explanou que os fatos demonstram que Antônio Francisco da Silva foi submetido a trabalho infantil, e que em razão da situação concreta de violência e escravidão à qual a criança havia sido submetida, da possibilidade de que outras crianças estivessem na mesma condição, bem como da gravidade dos fatos em questão, o Estado deveria ter adotado as medidas eficazes para: i) pôr fim à situação de escravidão identificada e para assegurar reabilitação e inserção social de Antônio Francisco da Silva; ii) assegurar seu acesso à educação básica primária e, caso fosse possível, sua formação profissional. Tendo em vista o anterior, a Corte considera que

\footnotetext{
${ }^{151}$ Corte IDH, 2016, p. 102.

152 Ibid., p. 103.
} 
o Estado violou o artigo 6.1, também em relação também ao artigo 19 do mesmo instrumento em relação ao senhor da Antônio Francisco da Silva ${ }^{153}$.

No tocante aos alegados desaparecidos, a Corte verificou que o Estado reabriu a investigação em 2007 sobre o desaparecimento de Iron Canuto, na qual ficou estabelecido que não havia sido vítima de desaparecimento forçado, enquanto que Luiz Ferreira da Cruz, a Corte se encontrou impossibilitada de concluir o mesmo, não podendo atribuir responsabilidade pela falta de investigação e eventual sanção dos alegados. Consequentemente, os juízes decidiram que o Estado não é responsável pelas alegadas violações aos direitos à personalidade jurídica, vida, integridade e liberdade pessoal, previstos no artigo 3,4, 5 e 7 da Convenção Americana, em relação aos direitos da criança, em prejuízo de Iron Canuto da Silva e Luis Ferreira da Cruz, tampouco violação aos artigos 8 e 25 da Convenção.

Por fim, no que concerne as medidas e garantias de não repetição, a Corte fixou que a sua sentença constitui per se uma forma de reparação ${ }^{154}$. À vista disso, estipulou medidas que buscam reparar tanto o dano imaterial que não possui cunho pecuniário quanto "medidas de alcance" ou "repercussão pública"155.

Por conseguinte, estipulou algumas recomendações, determinando que: (i) publique o resumo oficial da presente sentença elaborado pela Corte, por uma única vez, no Diário oficial, em um jornal de ampla circulação nacional e, a sentença integralmente, no período de um ano, em um sítio web oficial; (ii) adote, dentro de um prazo razoável, medidas legislativas necessárias para que a prescrição não seja aplicada à redução de pessoas à escravidão e suas formas análogas; (iii) pague os valores fixados na sentença, a título de indenização por dano imaterial, para cada um dos trabalhadores da Fazenda Brasil Verde, encontrados nas fiscalizações de 1997 e 2000; (iv) reembolse as custas e gastos dos representantes incorridos

\footnotetext{
${ }^{153}$ Corte IDH, 2016, p. 7.

154 Ibid., p. 123.

155 Ibid., p. 111.
} 
na tramitação do processo; e (v) reinicie, com a devida diligência, as investigações e/ou processos penais relacionados aos fatos constatados em março de 2000, visando que, em um prazo razoável, identifique, processo e, se for o caso, puna os responsáveis.

Por fim, a Corte ressaltou que supervisionará o cumprimento integral desta Sentença, no exercício de suas atribuições e no cumprimento de seus deveres, conforme a Convenção Americana sobre Direitos Humanos e o caso somente será concluído, uma vez que o Estado Brasileiro cumpra tudo o que foi descrito na mesma.

\subsubsection{Repercussões da sentença e seus desafios}

De acordo com Flávia Piovesan, ex-Secretária Nacional de Cidadania do Ministério de Direitos Humanos, a sentença da Corte Interamericana é emblemática e simboliza a voz regional do mais veemente repúdio à prática do trabalho escravo, como gravíssima violação a afrontar o âmago e a essência mesma do idioma dos direitos humanos - que é o idioma da alteridade, capaz de ver no outro um ser merecedor de igual consideração e profundo respeito, dotado do direito de desenvolver as potencialidades humanas de forma livre, autônoma e plena. Resgata a humanidade, a liberdade e a dignidade inerente a toda e qualquer pessoa, com seu valor único e infinito ${ }^{156}$.

Da mesma forma entende Beatriz Affonso, diretora do CEJIL para o programa do Brasil e co-peticionária do caso em análise, afirmou que a sentença é histórica e emblemática porque é a primeira vez que a proibição da escravidão e da servidão reconhece que tal violação se dá em um contexto de discriminação estrutural dos trabalhadores escravizados, principalmente em razão de sua situação de vulnerabilidade econômica ${ }^{157}$. Segundo a diretora, a sentença ainda cria um precedente importante ao

\footnotetext{
156 CONATRAE, 2017 , p. 37-40.
}

${ }^{157}$ Ibid., p. 89- 92. 
defender a natureza imprescritível de crime de submissão de pessoas à condição análoga à de escravo.

$\mathrm{Na}$ opinião do Frei Xavier Plassat, coordenador da Campanha contra o Trabalho Escravo da CPT, a sentença da Corte cumpriu seu papel elucidativo e provocador: porque ela descreve um sistema de escravidão moderna que ainda perdura na atualidade, pois se fundamenta na permanência de "discriminações estruturais históricas"; e porque ela identifica responsabilidades que o Estado brasileiro deixou de assumir (e às quais hoje pretende até se furtar) para reverter tais discriminações, embora estivesse perfeitamente informado ${ }^{158}$.

Destaca que a sentença alcançou o objetivo em $80 \%$ e com avanços muito importantes: (i) uma definição atualizada da escravidão moderna, à luz das mais respeitadas jurisprudências internacionais, e no contexto do moderno tráfico de pessoas; (ii) reforçou a definição a conceituação legal adotada pelo Brasil (art. 149 CPB) a partir de 2003; (iii) reconhecimento da responsabilidade internacional do Estado brasileiro, claramente caracterizada e demonstrada, inclusive reforçada pelo altíssimo valor das indenizações alocadas às vítimas pela Corte; (iv) clara injunção ao Estado para se conformar à lei internacional em relação à proibição da prescrição do crime de trabalho escravo; (v) sinalização para a comunidade internacional, especialmente quando parte do SIDH, para integrar esse balizamento normativo atualizado; (vi) elaboração consistente da obrigação do Estado em prevenir, reprimir e reparar, garantindo o acesso à justiça para as vítimas, dentro da rica conceituação da chamada "discriminação estrutural histórica" e (vii) vedação clara ao Estado brasileiro de tentar retroceder no caminho já percorrido - e elogiado pela Corte - de uma política consistente de combate ao trabalho escravo contemporâneo ${ }^{159}$.

No entanto, aduz o coordenador do CPT que os $20 \%$ de ressalva se devem à opção assumida pela Corte de não especificar quais ações

${ }^{158}$ CONATRAE, 2017, p. 47-50.

${ }^{159}$ PLASSAT, 2018. 
concretas de políticas públicas poderiam ser implementadas para atender a essa obrigação de reparar a discriminação estrutural histórica. Entretanto, ressalta que força da sentença Brasil Verde tem contribuído e muito a alimentar a resistência às tentativas golpistas visando o desmantelamento dos direitos construídos nas últimas décadas, na área da promoção do trabalho decente, e contra a banalização do trabalho escravo.

Lelio Bentes Corrêa, Corregedor Geral da Justiça do Trabalho, explanou que a sentença prolatada pela Corte Interamericana de Direitos Humanos é precisa no exame dos fatos, escorreita nos fundamentos jurídicos e contundente nas conclusões. Incumbe, agora, ao Estado brasileiro, por suas três esferas do Poder e em todos os níveis, dar concretude às suas disposições, cumprindo fielmente os ditames daquele órgão jurisdicional internacional, cuja competência foi voluntariamente reconhecida pelo Estado brasileiro em $1998^{160}$.

Segundo Mércia Consolação Silva, diretora executiva do Instituto Pacto Nacional pela Erradicação do Trabalho Escravo (InPACTO), o problema da exploração do trabalho escravo tem escala global e somente as ações conjuntas entre governo, setor empresarial e sociedade podem dar resposta e soluções para esse desafio. Destaca que construir um Brasil novo demandará ações articuladas, colaborativas e com apoio contínuo de políticas públicas para multiplicação e melhoria de postos de trabalho ${ }^{161}$.

${ }^{160}$ CONATRAE, 2017, p. 75-80.

${ }^{161}$ Ibid., p. 69-72. 


\section{CONCLUSÃO}

No dia 13 de maio desse ano vigente "comemoramos" os 130 anos da "abolição" da escravatura com a chamada Lei Áurea - resultado de movimentos sociais de luta e de resistência. Assim, embora a escravidão pareça uma discussão antiga e sem fundamento, as raízes do escravismo brasileiro continua em sua dimensão política e social até os dias de hoje, principalmente, enraizada nas Zonas Rurais. Contudo, atualmente, estão sendo descobertos muitos casos de exploração de trabalho escravo nas Zonas Urbanas.

Segundo o Observatório Digital de Trabalho Escravo ${ }^{162}$, calcula-se que foram resgatados, no país, mais de 50 mil $^{163}$ pessoas do trabalho em condição análogo de escravo, Todavia, o período considerado para a construção do Observatório se inicia no ano de lançamento do I Plano Nacional de Erradicação do Trabalho Escravo (2003), a partir do qual é possível compilar e detalhar, com mais consistência, as informações do Seguro-Desemprego do Trabalhador Resgatado (Lei n. 10.608, de 20 de dezembro de 2002, que alterou a Lei n. 7.998, de 11 de janeiro de 1990) em combinação com outras fontes, como o sistema COETE (Controle de Erradicação do Trabalho Escravo) ${ }^{164}$.

$\mathrm{O}$ grande ponto de pesquisa desse trabalho foi compreender se a ferramenta da litigância estratégica na arena do SIDH promoveu transformação externa e interna ao processo, isto é, se ocorreu a tematização do assunto e devolução do debate à sociedade, contribuindo para a erradicação do trabalho escravo e suas formas análogas.

162 O Observatório Digital do Trabalho Escravo foi desenvolvido e é mantido pelo Ministério Público do Trabalho em cooperação com a Organização Internacional do Trabalho no âmbito do fórum Smartlab de Trabalho Decente. Foram utilizados bancos de dados governamentais de várias fontes, incluindo registros administrativos, dados censitários, dados domiciliares e dados do Sistema de Indicadores Municipais de Trabalho Decente da OIT.

${ }^{163}$ Dados atualizados até 30 de novembro de 2017.

${ }^{164}$ Mais informações: Disponível em: 〈https://observatorioescravo.mpt.mp.br/>. Acesso em: 21 mai. 2018. 
Necessário destacar que conjuntamente ao litígio estratégico no SIDH, há a Organização Internacional do Trabalho (OIT) fundada em 1919, com objetivo da busca pela justiça social como condição para a paz permanente e contribuir com a promoção do trabalho decente no mundo. Ao longo dos anos, a OIT tem elaborado a partir de um processo de discussão tripartite protagonizado pelos governos, organizações de empregadores e de trabalhadores de seus Estados-Membros as normas internacionais de trabalho ${ }^{165}$.

Diante de todo o exposto, resta inequívoco o corolário de que o instrumento da litigância estratégica foi utilizado no Caso Fazenda Brasil Verde, na realidade podemos até considerar que ocorreu o uso da ferramenta do litígio de impacto na Solução Amistosa no Caso José Pereira, uma vez que foi um relevante marco para o enfretamento ao trabalho escravo contemporâneo no Brasil, na qual resultou em diversos Planos do Governo de Erradicação de Trabalho Escravo, criação da Comissão Nacional de Erradicação do Trabalho Escravo (CONATRAE), Mudanças Legislativas, Pacto Nacional pela Erradicação do Trabalho Escravo, Lista Suja dentre outros.

Apesar disso, não podemos esperar que a determinação de responsabilização internacional da Corte Interamericana surte efeitos imediatamente. Considerando que a submissão de um outro caso de trabalho escravo contra o Brasil ao SIDH, já demonstra o quanto a realidade brasileira não busca erradicar toda essa situação de discriminação estrutural histórica marcada pelas amarras da escravidão.

Conquanto, o objetivo principal do litígio estratégico é modificar a realidade de violação de um direito e buscar a efetiva internalização dessa jurisprudência internacional no âmbito doméstico, bem como funcionar como standart para todo o sistema interamericano.

165 OIT. Perfil dos Principais Atores Envolvidos no Trabalho Escravo Rural no Brasil. Organização Internacional do Trabalho. Brasília: 2011. Disponível em: <http://www.justica.sp.gov.br/StaticFiles/SJDC/ArquivosComuns/ProgramasProjetos/NETP/Relat \%C3\%B3rio\%20OIT.\%20Trabalho\%20Escravo\%20Rural\%20Brasil.\%202011.pdf>. Acesso em: 02 jun. 2018. 
Desta forma, podemos observar que a tematização do assunto e a devolução do debate à sociedade está acontecendo. Podemos ver como esse tema passou a ser temporiamente um dos temas do cotidiano das pessoas do Brasil, por exemplo, com a discussão sobre o trabalho escravo em uma emissora de TV do país, a Rede Globo, quando televisionou uma novela denominada O Outro Lado do Paraíso ${ }^{166}$, onde foi exibida a prisão de Sophia, a personagem de Marieta Severo, após desacato a autoridades durante uma fiscalização de denúncia de trabalho escravo ${ }^{167}$. Outro cenário que também ampliou o debate sobre conceito da escravidão foi o Desfile da Escola de Samba da Paraíso do Tuiuti do Rio de Janeiro com o enredo “Meu Deus, meu Deus, está extinta a escravidão?"168169.

Destaco a atuação de jornalismo, pesquisa, educação e articulação realizada pela ONG Repórter Brasil cujo objetivo é de fomentar a reflexão e ação sobre a violação aos direitos fundamentais dos povos e trabalhadores no Brasil. Devido ao seu trabalho, tornou-se uma das mais importantes fontes de informação sobre trabalho escravo no país. Suas reportagens, investigações jornalísticas, pesquisas e metodologias educacionais têm sido usadas por lideranças do poder público, do setor empresarial e da sociedade civil como instrumentos para combater a escravidão contemporânea, um problema que afeta milhares de pessoas ${ }^{170}$. Consequentemente, a ONG coleciona diversos prêmios e homenagens na atuação em defesa dos direitos

\footnotetext{
${ }^{166}$ Veja a cena onde ocorreu a interdição do local pela prática de trabalho escravo. Disponível em: <https://globoplay.globo.com/v/6392872/>. Acesso em: 21 mai. 2018.

${ }^{167} \mathrm{Na}$ trama, a Sophia é dona de uma mina de esmeralda na qual os trabalhadores são submetidos a jornadas exaustivas e condições degradantes de trabalho. A novela mostrou a importância dos conceitos de condição degradante de trabalho, jornada exaustiva, servidão por dívida e trabalho forçado para configuração da condição de trabalho análoga à de escravo.

168 Samba da Paraíso do Tuiuti amplia debate sobre conceito de escravidão. O Globo. Disponível em: <https://oglobo.globo.com/rio/bairros/samba-da-paraiso-do-tuiuti-amplia-debate-sobreconceito-de-escravidao-2235364>. Acesso em: 02 jun. 2018.

${ }^{169}$ YOUTUBE. Desfile da Escola de Samba da Paraíso do Tuiuti do Rio de Janeiro, 2018.

Disponível em: <https://www.youtube.com/watch?v=RkVKiEzQMUw>. Acesso em: 12 mai. 2018.

${ }^{170}$ Mais informações sobre a atuação da ONG.

Disponível em: <http://reporterbrasil.org.br/quem-somos/>. Acesso em: 20 mai. 2018.
} 
humanos ${ }^{171}$. Ademais, recomendo a reportagem "Eu fui escravo" sobre o caso Brasil Verde elaborada pela $\mathrm{ONG}^{172}$.

Além disso, as inúmeras campanhas elaboradas pela Organizações das Nações Unidas (ONU) do Brasil junto com o Embaixador da OIT, Wagner Moura, para que o Brasil assine o Tratado Internacional de Combate ao Trabalho Forçado.

Conforme demonstrado no presente trabalho, conclui-se, pois que, se bem estruturado, o litígio estratégico alcança o seu objetivo principal de repercutir forte e positivamente no combate institucional à escravidão no Brasil e em toda a América. Nesse sentido, o real enfretamento ao trabalho escravo se dará pela adoção ações conjuntas de prevenção, repressão ao crime e assistência às vítimas.

${ }^{171}$ Mais informações sobre as premiações. Disponível em: <http://reporterbrasil.org.br/premios/>. Acesso em: 20 mai. 2018.

172 REPÓRTER BRASIL. Reportagem "Eu fui escravo". Disponível em: <http://reporterbrasil.org.br/brasilverde/>. Acesso em: 20 mai. 2018. 


\section{REFERÊNCIAS BIBLIOGRÁFICAS}

ABRAMOVICH, Victor. Das violações em massa aos padrões estruturais: novos enfoques e clássicas tensões no sistema interamericano de direitos humanos. In: SUR - Revista Internacional de Direitos Humanos. v. 6, no. 11, dez 2009. p. 6-39. Disponível em:

$<$ http://www.scielo.br/scielo.php?pid=S1806-

$64452009000200002 \&$ script=sci_abstract\&tlng=pt $>$. Acesso em: 12 mai. 2018.

AFFONSO, Beatriz; FREUND, Rita Lamy. Efeitos Práticos das Decisões dos Órgãos do Sistema Interamericano de Direitos Humanos. Disponível em: <https://www.social.org.br/relatorio2005/relatorio035.htm>. Acesso em: 12 mai. 2018.

ALVAREZ. M. Ignacio. Introdução ao Sistema Interamericano de Promoção e Proteção dos Direitos Humanos In: I Colóquio Internacional de Direitos Humanos, São Paulo, 2001. p. 12. Disponível em:

$<$ http://www.dhnet.org.br/direitos/sip/oea/textos/alvarez_introducao_oea.pdf >. Acesso em: 12 mai. 2018.

AZEVEDO NETO, Platon Teixeira de. A justiciabilidade dos Direitos Sociais nas Cortes Interamericanas de Justiça. São Paulo: LTr, 2017, 263p.

Acordo de Cooperação Geral entre a Secretaria Geral da OEA e a AIDEF, disponível em: <https://www.mpd.gov.ar/users/uploads/1402684164Acuerdo\%20final $\% 20$ OEA\%20AIDEF.pdf >

Acordo de Entendimento entre a CIDH e a Associação Interamericana de Defensorias Públicas

<https://www.mpd.gov.ar/index.php/component/content/article/126internacional/aidef/470-reglamento-unificado-aidef-ante-cidh-y-corteidhaprobado-en-antigua-guatemala-el-7-de-junio-de-2013.html?Itemid=101>. Acesso em: 12 maio 2018.

BERNARDES, Marcia Nina. Sistema Interamericano de Direitos Humanos como esfera Pública Transnacional: Aspectos Jurídicos e Políticos de Implementação de Decisões Internacionais. In: Revista SUR, v. 8, no. 15, dez. 2011. p. 135-156. Disponível em:

<https://bdjur.stj.jus.br/jspui/bitstream/2011/46810/sistema_interamericano_ direitos_bernardes.pdf $>$. Acesso em: 12 mai. 2018. 
BRASIL. Ministério do Trabalho. Manual de Combate ao Trabalho em Condições Análogas à de Escravo, 2011, 98p.

CARDOSO, Evorah Lusci Costa. Ciclo de vida do litígio estratégico no Sistema Interamericano de Direitos Humanos: dificuldades e oportunidades para atores não estatais In: Revista Electrónica del Instituto de Investigaciones Jurídicas y Sociales Ambrosio L. Gioja, Buenos Aires (Argentina), año V, n. especial, 2011. p. 363-378. Disponível em: <http://cebrap.org.br/bibliotecavirtual/arquivos/272_artigo.pdf>. Acesso em: 21 mai. 2018.

Litígio Estratégico e o Sistema Interamericano de Direitos Humanos. Belo Horizonte: Editora Fórum, 2012, 220p.

CARVALHO, Sandra; BAKER, Eduardo. Experiência de litígio estratégico no Sistema Interamericano de Proteção dos Direitos Humanos. In: Revista SUR, v. 11, n. 20, jun/2014. p. 465-475. Disponível em:

<https://bdjur.stj.jus.br/jspui/handle/2011/90747>. Acesso em: 04 abr. 2018.

Caso Velásquez vs. Honduras. Disponível em:

<http://www.cnj.jus.br/files/conteudo/arquivo/2016/04/2ed9f5488d3b613fb

7364d2008a0c3a1.pdf>. Acesso em: 12 mai. 2018.

CAVALLARO, James L; SCHAFFER, E.J. 2004. Less as More: Rethiking Supranational Litigation of Economic and Social Rights in the Americas. 2004 apud BERNARDES, Marcia Nina. Sistema Interamericano de Direitos Humanos como esfera Pública Transnacional: Aspectos Jurídicos e Políticos de Implementação de Decisões Internacionais. In: Revista SUR, v. 8, no. 15, dez. 2011. p. 140. Disponível em: <https://bdjur.stj.jus.br/jspui/bitstream/2011/46810/sistema_interamericano _direitos_bernardes.pdf>. Acesso em: 12 mai. 2018.

; BREWER, Stephanie Erin. O papel da litigância para a justiça social no Sistema Interamericano In: SUR - Revista Internacional de Direitos Humanos. ano 5, n. ${ }^{\circ}$, São Paulo, junho de 2008, p. 85-99. Disponível em: <https://bdjur.stj.jus.br/jspui/handle/2011/18129>. Acesso em: 12 mai. 2018.

CEJIL (Centro por la Justicia y el Derecho Internacional). Guia para defensores y defensoras de Derechos Humanos. 2a ed. Buenos Aires, 2012. p. 103 apud SCHETTINI, Andrea Bandeira de Melo; FERREIRA, Natalia Damazio Pinto. Uma introdução ao Sistema Interamericano de proteção dos direitos humanos: reflexões sobre sua história, estrutura e o recente posicionamento do Estado Brasileiro. CONPEDI, 2016. p. 165. Disponível em: 
<https://www.conpedi.org.br/publicacoes/y0ii48h0/va83towp/d8E6kevG2 W3HUq56.pdf>. Acesso em: 12 mai. 2018.

. Disponível em: <https://cejil.org/en/fazenda-brasil-verde>. Acesso em: 12 mai. 2018.

. Disponível em: <https://cejil.uwazi.io/pt/entity/j8g5vtqs5zqzd7vi>. Acesso em: 06 jan. 2018.

CELS. Litigio estratégico y derechos humanos: La lucha por el derecho. $1^{\mathrm{a}}$ ed. Buenos Aires: Siglo Vienteuno Editores, 2008. p. 17. Disponível em: <https://www.idl.org.pe/sites/default/files/publicaciones/pdfs/GuiaIDL.pdf>. Acesso em: 04 abr. 2018.

CHILD RIGHTS INTERNATIONAL NETWORK (CRIN). Disponível em: $<$ https://www.crin.org/en/guides/legal/guide-strategic-litigation/whatstrategic-litigation>. Acesso em: 01 jun. 2018.

CIDH, Relatório Relatório n. ${ }^{\circ}$ 169/11, Caso 12.066, 2011, 70p. Disponível em:

<http://www.corteidh.or.cr/docs/casos/trab_hacienda_brasil_verde_br/some tim_port.pdf $>$. Acesso em: 16 maio. 2018.

CLÍNICA DE TRABALHO ESCRAVO DA UFMG. Entrevista concedida a Thainá Mamede. 24 mai. 2018.

CONATRAE. Trabalho Escravo: Condenação do Brasil pela Corte Interamericana de Direitos Humanos no caso Fazenda Brasil Verde. Brasília, 2017. 106p. Disponível em:

<https://www.dropbox.com/s/2ow5tdoqmzmd9lc/LIVRO\%20DA\%20CONA TRAE\% $20 \% 20 \% 27$ TRAB ALHO $\% 20$ ESCRAVO\%20-

$\%$ 20SENTEN\%C3\%87A\%20BRASIL\%20VERDE\%27.pdf?dl=0>. Acesso em: 21 abr. 2018.

CONECTAS. Dossiê OEA: Sistema sob ataque, 2012. Disponível em: $<$ http://old.conectas.org/pt/acoes/politica-externa/noticia/dossie-oea>.

Acesso em: 20 mai. 2018.

CORAL-DÍAZ, Ana Milena et al.. El concepto de Litigio Estratégico en América Latina. 1990-2010., Botogá (Colômbia): Vniversitas, n. 121, julio/diciembre, 2010, p. 49-75. Disponível em:

<http://revistas.javeriana.edu.co/index.php/vnijuri/article/view/14413>.

Acesso em: 03 mar. 2018. 
CORTE IDH. ABC de la Corte Interamericana de Derechos Humanos: El qué, cómo, cuándo, dónde y porqué de la Corte Interamericana. Preguntas frecuentes / Corte Interamericana de Derechos Humanos. San José, C.R.: Corte IDH, 2018. 24 p. Disponível em:

<http://www.corteidh.or.cr/sitios/libros/todos/docs/ABCCorteIDH.pdf>. Acesso em: 20 mai. 2018.

Interpretação da Declaração Americana dos Direitos e Deveres do Homem. Opinião Consultiva OC-10/89.

Resumo oficial emitido pela Corte IDH. 9p. Disponível em:

<http://www.corteidh.or.cr/docs/casos/articulos/resumen_318_por.pdf>. Acesso em: 05 mai. 2018.

Caso Velásquez Rodríguez. Disponível em:

<http://www.corteidh.or.cr/docs/casos/articulos/seriec_04_esp.pdf >. Acesso em: 12 mai. 2018.

Sentença do Caso Trabalhadores da Fazenda Brasil Verde vs. Brasil, 2016. 164p. Disponível em: <http://www.corteidh.or.cr/docs/casos/articulos/seriec_318_por.pdf>. Acesso em: 15 mai. 2018.

CRIN (Child Rights International Network), Cuàndo Debría de Tramitarse El Litigio Estratégico? 2008. Disponível em:

<https://www.crin.org/en/library/publications/cuando-deberia-de-tramitarseel-litigio-estrategico>. Acesso: 19 mai. 2018.

CUMMINGS, Scott L; RHODE, Deborah. Public Interest Litigation: Insights from Theory and Practice. In: Fordham Urban Law Journal, v. XXXVI, UCLA School of Law, 2009. p. 606. Disponível em: $<$ https://papers.ssrn.com/sol3/papers.cfm?abstract_id=1425097>. Acesso em: 05 jan. 2018.

Declaração Americana dos Direitos e Deveres do Homem, 1948. Disponível em:

<https://www.cidh.oas.org/basicos/portugues/b.Declaracao_Americana.htm >. Acesso em: 12 mai. 2018.

Disponível em: <https:/globoplay.globo.com/v/6392872/>. Acesso em: 21 mai. 2018.

Disponível em: <www.pilnet.org/.../doc.../35-pursuing-the-public-interesta-handbook-for-legal.html>. Acesso em: 12 mai. 2018. 
Documento de envio do caso para a Corte IDH. Disponível em: <https://www.oas.org/es/cidh/decisiones/corte/2015/12066NdeResPT.pdf>. Acesso em: 12 mai. 2018.

ERRC, INTERIGHTS, MPG, Strategic Litigation of race discrimination in Europe: From Principles to Practice. European Roma Rights Centre ERRC, Interights, Migration Policy Group - MPG, 2004. A Manual on the Theory and Practice of Strategic Litigation with Particular Reference to the EC Race Directive. p. Disponível em:

<http://www.errc.org/uploads/upload_en/file/00/C5/m000000C5.pdf>.

Acesso em: 15 abr. 2018.

ESCOLA SUPERIOR DA DEFENSORIA PÚBLICA DA UNIÃO, Litigância Estratégica. 2018, 12p. Disponível em:

<http://www.dpu.def.br/images/esdpu/jornaldpu/edicao_12/informativo_ES COLA_ed12_ano4._Definitivo.pdf >. Acesso em: 02 mai. 2018.

Escrito de petições, argumento e provas pela CPT e CEJIL perante a Corte IDH. 2015, 191p. Disponível em:

<http://www.corteidh.or.cr/docs/casos/trab_hacienda_brasil_verde_br/esap. pdf $>$. Acesso em: 06 jan. 2018.

Estatuto da Comissão Interamericana de Direitos Humanos. Disponível em: <http://www.cidh.org/basicos/portugues/t.estatuto.cidh.htm>. Acesso em: 20 mai. 2018.

FIGUEIRA, Ricardo Rezende. O trabalho escravo contemporâneo por divida: como se manifestam os acusados? Conferência na Universidade Salgado Oliveira, 2002.

O trabalho escravo contemporâneo por dívida: como se manifestam os acusados? Conferência na Universidade Salgado Oliveira, 2002 apud ROCHA, Cristina Costa. Trabalhadores da Fazenda Brasil Verde vs; Brasil: trajetórias de luta por justiça de trabalhadores escravizados. Disponível em:

$<$ http://wpro.rio.rj.gov.br/revistaagcrj/wpcontent/uploads/2016/12/Dossi\%C3\%AA_Artigo-3.pdf >. Acesso em: 06 jan. 2018.

FOLHA DE SÃO PAULO, Disponível em: $<$ https://www1.folha.uol.com.br/fsp/opiniao/59213-sistema-interamericanosob-forte-ataque.shtml>. Acesso em: 20 mai. 2018. 
Guilherme de Aguiar Patriota: Dois pesos, duas medidas.

Disponível em: <https://www1.folha.uol.com.br/fsp/opiniao/59211 dois-pesos-duas-medidas.shtml>. Acesso em: 20 mai. 2018.

FREUND, Rita. O primeiro caso de trabalho escravo decidido pela Corte Interamericana de Direitos Humanos é brasileiro. Escola Superior da Defensoria Pública da União. Disponível em:

$<$ http://www.dpu.def.br/images/esdpu/jornaldpu/edicao_8/4-o-primeirocaso.pdf $>$. Acesso em: 15 mai. 2018.

GARCIA, Emerson. Proteção Internacional dos Direitos Humanos Breves reflexões sobre os sistemas convencional e não-convencional. Rio de Janeiro: Lumen Juris, 2005.

GOMEZ, José Maria. Globalização dos direitos humanos, legado das ditaduras militares no Cone Sul latino-americano e justiça transicional In: Direito, Estado e Sociedade: Revista do Departamento de Direito da PUCRio. Rio de Janeiro, n. 33.

IJRC (International Justice Resource Center). Atuação perante o Sistema Interamericano: Manual para advogados e ativistas, 2014, 277p. Disponível em: $\quad$ http://ijrcenter.org/wp-content/uploads/2014/03/Manual-Atuacaoperante-o-Sistema-Interamericano-2014.pdf>. Acesso em: 12 mar. 2018.

INTERNATIONAL HUMAN RIGHTS LAW GROUP - IHRLG. Promoting Justice: A Practical Guide to Strategic Human Rights Lawyering. Washinton: International Human Right Group, 2001. p. 135. Disponível em: <http://www.sbdp.org.br/arquivos/material/280_IHRLG__International_Human_Rights_Law_Group_-_Promoting_justice__a_pratical_guide_to_strategic_HR_lawyering.pdf >. Acesso em: 10 mai. 2018.

LEVY, Leonard W. et al.. Encyclopedia of the American Constitution. New York: Macmilian Publishing Company, 2000. p. 231-237 apud MANEIRO, Renata de Marins Jaber; PULCINELLI, Eliana. Litígio estratégico, vinculação de precedentes e abertura ao diálogo constitucional do provimento jurisdicional In: Revista de Investigações Constitucionais, Curitiba, v. 4, n. 2, p. 194-195, maio/ago.2017. Disponível em: <revistas.ufpr.br/rinc/issue/download/2378/414>. Acesso em: 10 mai. 2018.

MACHADO, Isabel Penido de Campos. Defensores Públicos Interamericanos: novos horizontes de acesso à justiça. 2017, 12p. Disponível em: 
<http://www.dpu.def.br/images/esdpu/jornaldpu/edicao_8/forum-8edicao.pdf $>$. Acesso em: 02 mai. 2018.

MACHADO, N. P. L. O papel das organizações não governamentais e o Sistema Interamericano de Direitos Humanos. Brasília, 2014. 188 p. Tese de Mestrado (Graduação em Direito) - Centro Universitário de Brasília. Disponível em:

<http://repositorio.uniceub.br/bitstream/235/8607/1/61200011.pdf>. Acesso em: 16 mai. 2018.

MANEIRO, Renata de Marins Jaber; PULCINELLI, Eliana. Litígio estratégico, vinculação de precedentes e abertura ao diálogo constitucional do provimento jurisdicional. Revista de Investigações Constitucionais, Curitiba, v. 4, n. 2, p. 194, maio/ago.2017. Disponível em: <https://revistas.ufpr.br/rinc/article/view/50125>. Acesso em: 10 mai. 2018.

MAZZUOLI, Valério de Oliveira. Curso de Direito Internacional Público. $7^{\mathrm{a}}$ ed. São Paulo: Editora Revista dos Tribunais, 2013.

MENTAL DISABILITY ADVOCACY CENTRE. Disponível em: <http://mdac.org/en/what-we-do/strategic_litigation>. Acesso em: 01 jun. 2018.

MONTOYA, Lucas Correa. Litigio de alto impacto: Estrategias alternativas para enseñar y ejercer el Derecho. Opin. Jurid, v. 7, n. 14, p. 151. JulioDiciembre de 2008. Universid de Medellín. Disponível em: <https://revistas.udem.edu.co/index.php/opinion/article/view/161/145> Acesso em: 04 fev. 2018.

Observatório Digital de Trabalho Escravo. Disponível em: <https://observatorioescravo.mpt.mp.br/>. Acesso em: 21 mai. 2018.

OEA. Sobre a estrutura do SIDH. Disponível em:

<http://www.oas.org/pt/sobre/comissao_direitos_humanos.asp>. Acesso em: 20 mai. 2018.

Sobre o fortalecimento. Disponível em:

<http://www.oas.org/pt/cidh/fortalecimento/consulta2013.asp>. Acesso em: 12 mai. 2018.

OIT. Perfil dos Principais Atores Envolvidos no Trabalho Escravo Rural no Brasil. Organização Internacional do Trabalho. Brasília: 2011. Disponível em:

<http://www.justica.sp.gov.br/StaticFiles/SJDC/ArquivosComuns/Programas 
Projetos/NETP/Relat\%C3\%B3rio\%20OIT.\%20Trabalho\%20Escravo\%20Ru ral\%20Brasil.\%202011.pdf>. Acesso em: 12 mai. 2018.

PIOVESAN, Flávia. Direitos Humanos e Justiça Internacional. $4^{\mathrm{a}}$ ed. São Paulo: Saraiva, 2013.

PIZZOLO, Calogero. Sistema Interamericano: La denuncia ante La Comision Interamericana de Derechos Humanos, El processo ante La Corte Interamericana de Derechos Humanos, Informes y Jurisprudência. $1^{a}$ ed. Buenos Aires: 2011, p. 399 apud SCHETTINI, Andrea Bandeira de Melo; FERREIRA, Natalia Damazio Pinto. Uma introdução ao Sistema Interamericano de proteção dos direitos humanos: reflexões sobre sua história, estrutura e o recente posicionamento do Estado Brasileiro. CONPEDI, 2016. p. 164. Disponível em:

<https://www.conpedi.org.br/publicacoes/y0ii48h0/va83towp/d8E6kevG2 W3HUq56.pdf>. Acesso em: 12 mai. 2018.

PLASSAT, Frei Xavier. Entrevista concedida a Thainá Mamede. 23 maio, 2018.

PRONER, Carolina. Sistema Interamericano de Direitos Humanos precisa ser reformado? 2012 apud SCHETTINI, Andrea Bandeira de Melo; FERREIRA, Natalia Damazio Pinto. Uma introdução ao Sistema Interamericano de proteção dos direitos humanos: reflexões sobre sua história, estrutura e o recente posicionamento do Estado Brasileiro. CONPEDI, 2016. p. 156. Disponível em:

<https://www.conpedi.org.br/publicacoes/y0ii48h0/va83towp/d8E6kevG2 W3HUq56.pdf>. Acesso em: 12 mai. 2018.

REPÓRTER BRASIL. Reportagem “Eu fui escravo”. Disponível em: $<$ http://reporterbrasil.org.br/brasilverde/>. Acesso em: 20 mai. 2018.

Disponível em: <http://reporterbrasil.org.br/premios/>. Acesso em: 20 mai. 2018.

Disponível em: <http://reporterbrasil.org.br/quem-somos/>. Acesso em: 20 mai. 2018.

ROCHA, Cristina Costa. Trabalhadores da Fazenda Brasil Verde vs; Brasil: trajetórias de luta por justiça de trabalhadores escravizados. Disponível em: $<$ http://wpro.rio.rj.gov.br/revistaagcrj/wpcontent/uploads/2016/12/Dossi\%C3\%AA_Artigo-3.pdf>. Acesso em: 10 mai. 2018. 
Samba da Paraíso do Tuiuti amplia debate sobre conceito de escravidão. O Globo. Disponível em: <https://oglobo.globo.com/rio/bairros/sambada-paraiso-do-tuiuti-amplia-debate-sobre-conceito-de-escravidao2235364>. Acesso em: 02 jun. 2018.

SANTOS, Cecília Macdowell Santos. Ativismo jurídico transnacional e o Estado: reflexões sobre os casos apresentados contra o Brasil na Comissão Interamericana de Direitos Humanos In: SUR - Revista Internacional de Direitos Humanos. v. 4, $\mathrm{n}^{\mathrm{o}}$ 7. São Paulo, 2007. p. 33. Disponível em: $<$ http://www.scielo.br/scielo.php?pid=S1806-

64452007000200003\&script=sci_abstract\&tlng=pt $>$. Acesso em: 12 mai. 2018.

Memória na Justiça: A mobilização dos direitos humanos e a construção da memória da ditadura no Brasil In: Revista Crítica de Ciências Sociais. no. 88, 2010. p. 127-154 apud SCHETTINI, Andrea Bandeira de Melo; FERREIRA, Natalia Damazio Pinto. Uma introdução ao Sistema Interamericano de proteção dos direitos humanos: reflexões sobre sua história, estrutura e o recente posicionamento do Estado Brasileiro. CONPEDI, 2016. p. 154. Disponível em:

<https://www.conpedi.org.br/publicacoes/y0ii48h0/va83towp/d8E6kevG2 W3HUq56.pdf>. Acesso em: 12 mai. 2018.

SCHETTINI, Andrea Bandeira de Mello. A era do biopoder o discurso dos direitos humanos: um olhar genealógico a partir da obra de Michel Foucalt. Rio de Janeiro. 2013. 145 p. Dissertação (Mestrado) - Departamento de Direito da PUC-Rio. Disponível: <http://www.dbd.puc-

rio.br/pergamum/tesesabertas/1112591_2013_completo.pdf $>$. Acesso: 02 fev. 2018.

Os Padrões Estabelecidos pela Corte Interamericana de Direitos Humanos sobre Liberdade de Expressão e a Análise do Caso Ríos e Outros vs. Venezuela. Rio de Janeiro. 2010. 70 p. Monografia (Graduação em Direito) - Departamento de Direito da PUC-Rio. Disponível em:

$<$ https://www.maxwell.vrac.pucrio.br/acessoConteudo.php?nrseqoco=54612>. Acesso: 02 mai. 2018.

; FERREIRA, Natalia Damazio Pinto. Uma introdução ao Sistema Interamericano de proteção dos direitos humanos: reflexões sobre sua história, estrutura e o recente posicionamento do Estado Brasileiro. CONPEDI, 2016. Disponível em: <https://www.conpedi.org.br/publicacoes/y0ii48h0/va83towp/d8E6kevG2W 3HUq56.pdf>. Acesso em: 12 mai. 2018. 
VILLARREAL, Marta. El litigio estratégico como herramienta del Derecho de Interés Público In: MATUS, Fabián Sanchez. El litigio estratégico em México: la aplicación de los derechos humanos a nível práctico, experiencias de la sociedade civil. México: Alto Comissionado de las Naciones Unidas, 2007. p. 18. Disponível em:

<https://www.hchr.org.mx/images/doc_pub/litigioestrategico.pdf >. Acesso em: 05 mar. 2018.

WASHINGTON COLLEGE OF LAW (WCL). Proyecto del litigio. Washington, 2007. apud MONTOYA, Lucas Correa. Litigio de alto impacto: Estrategias alternativas para enseñar y ejercer el Derecho. Opin. Jurid, v. 7, n. 14, p. 151. Julio-Diciembre de 2008. Universid de Medellín. Disponível em: <https://revistas.udem.edu.co/index.php/opinion/article/view/161/145> Acesso em: 04 fev. 2018.

WILSON, Richard J. RASMUSEN, Jennifer. Promoting Justice: A Practical Guide to Strategic Human Rights Lawyering. International Human Rights Law Group, 2001. p. 60. Disponível em:

<http://pdf.usaid.gov/pdf_docs/Pnadf477.pdf>. Acesso em: 12 mai. 2018.

YOUTUBE. Fazenda Brasil Verde - Testemunho de Marcos Antonio Lima, 2016. Disponível em: <https://www.youtube.com/watch?v=FwQBPsRBTc>. Acesso em: 16 abril 2018

Reportagem do Fantástico sobre Trabalho Escravo, 2017. Disponível em: <https://www.youtube.com/watch?v=HI8x5W9KTs\&t=28s>. Acesso em: 19 abril 2018.

Reportagem do Profissão Repórter. 29 nov. 2017. Disponível em: $<$ https://www.youtube.com/watch?v=ds3NtVcWX58\&t=654s> Acesso em: 27 abril. 2018.

Trabalho Escravo na Fazenda Brasil Verde: Testemunho de Pedro Fernandes, 2017. Disponível em:

<https://www.youtube.com/watch?v=8ufV8SuVx1g>. Acesso em: 16 abril 2018.

Trabalho Escravo. Canal Futura, 2018. Disponível em: $<$ https://www.youtube.com/watch?v=HI-8x5W9KTs\&t=28s>. Acesso em: 10 abril 2018.

. Wagner Moura fala do combate ao trabalho escravo. Entrevista no programa "Conversa com Bial", da TV Globo, 2017. Disponível em: <https://www.youtube.com/watch?v=MxVRXtGQ0p8>. Acesso em: $20 \mathrm{dez}$ 2017. 
Desfile da Escola de Samba da Paraíso do Tuiuti RJ, 2018. Disponível em: <https://www.youtube.com/watch?v=RkVKiEzQMUw>. Acesso em: 12 mai. 2018. 


\title{
ANEXO A - ENTREVISTA COM A BEATRIZ AFFONSO (DIRETORA DO CEJIL PARA O PROGRAMA DO BRASIL)
}

\author{
1) O que é litigância estratégica no Sistema Interamericano na \\ concepção do CEJIL?
}

Na concepção do CEJIL, a litigância estratégica é uma forma de atuar onde temos alguns critérios específicos que são considerados na escolha do envio de determinadas denúncias para o Sistema Interamericano de Direitos Humanos (SIDH).

Nós entendemos que os casos que devem ser litigados no SIDH, em primeiro lugar, devem corresponder na respectiva sociedade a um padrão sistemático de graves violações de direitos humanos, isso significa que é absolutamente reincidente no País e lhe diz respeito a uma estrutura de uma formação social e institucional, na qual corrobora que determinadas violações de direitos humanos não só aconteçam - apesar de serem ilegais, apesar da maioria das vezes existir um ato normativo que determine o que são crimes e o que são violações graves -, mas que acima de tudo não consegue que os seus perpetradores venham responder judicialmente.

Além disso, situações em que não exista uma resposta adequada no sistema de justiça e uma estrutura adequada de combate daquele tipo de grave violação de direitos humanos naquela sociedade ou quando também o Estado não seja capaz de prevenir essas violações de direitos humanos, esse é o principal critério.

O segundo critério importante é o técnico, onde dentre as graves violações de direitos humanos que sejam recorrentes e que mereça ser denunciado no SIDH, há essa necessidade de uma resposta internacional e de parâmetros internacionais visando trazer uma reflexão para o Estado e para a sociedade sobre o que vem ocorrendo. Nós escolhemos entre os vários casos que temos acesso, por exemplo, de trabalho escravo, casos que nos permitam qualificar melhor aquela violação com documentação adequada, um número de provas formais daquelas violações que elas 
existiram e como elas existiram, qual é o modus operandi de quem pratica aquela violação, da mesma forma como elas não são investigadas e processadas e, portanto, permitem que os seus perpetradores permaneçam impunes e que não exista uma reflexão da sociedade ou daquela classe jurídica sobre as graves violações de direitos humanos ocorridos.

Sendo assim, escolhemos casos em que o sistema de justiça esteja funcionando não para reprimir, senão acabam por fomentar tais violações como essas sempre se repitam. Por isso o padrão sistemático não só da violação em si, mas da obstrução da realização da justiça que é um grande fomentador para a repetição das graves violações.

Dessa forma, quando denunciamos o Estado, aquela documentação deve ser explícita sobre o padrão sistemático e sobre a profundidade da cicatriz estrutural que aquela grave violação se dá no País, como é no caso de trabalho escravo, porque ela é decorrente da formação da sociedade brasileira que contou com a escravidão. Ocorreu por essa flexibilização da utilização da expropriação da força do trabalho do outro com naturalidade, com justificativas de que é bom para a sociedade porque é bom para o desenvolvimento e porque alguém, infelizmente, nasceu destituído de direito e que, portanto, tem seu trabalho e sua força de trabalho usurpada e, muitas das vezes agredida sua integridade física. Por isso, esse segundo critério é objetivo e importante porque trabalham sobre as provas que melhor documentem as violações perpetradas.

O terceiro critério mais abrangente diz respeito a dois contrapontos. O primeiro é que além da violação ser sistemática e recorrente, infelizmente acontece em um número realmente importante ao ponto que desestabilize uma sociedade, isto é, casos em que essas violações em si representam a nossa fragilidade democrática em dois âmbitos diferentes, sejam porque os perpetradores são diretamente relacionados às estruturas estatais, isto é, agentes públicos que utilizam a legitimidade, do poder bélico, do poder político, das estruturas que são utilizadas pelos outros servidores públicos, 
ou seja, esse tipo de "cooperação coletiva" para que nada aconteça e que os agentes públicos fiquem impunes mesmo quando cometem crimes.

Acreditamos que essas situações consistem uma grande inversão da democracia, na qual expõe e questiona os nossos parâmetros democráticos de forma séria e profunda. Desta maneira, esse é outro critério de escolha utilizado, posto que demonstram a nossa fragilidade democrática e a decorrência dela em que nenhum instrumento interno seja potente suficiente e eficiente para combater esse tipo de inversão - quando o Estado se apropria da legitimidade que nós cidadãos oferecemos para se voltar contra outro determinado cidadão, especialmente de forma ilegal, arbitrária e às vezes até criminosa -, isso pode se dar diretamente pela ação direta do perpetrador daquela violação de direitos humanos, como também ser marginalmente/indiretamente, quando, por exemplo, o Estado garante que aqueles que praticam o trabalho escravo que submetem pessoas ao trabalho escravo análogo contemporâneo não venham a ser investigadas e responsabilizadas, isto é, quando o próprio sistema de justiça e de polícia acabam fortalecendo pra que esse tipo de grave violação siga acontecendo. Em suma, quando temos um ator público direta ou indiretamente relacionado para fomentar essas graves violações de direitos humanos sistemáticas.

O segundo ponto ainda dentro desse critério de mudança de paradigma democrático diz respeito àquilo que entendemos como graves violações de direitos humanos e que não são aceitos culturalmente pela sociedade, um exemplo simbólico é do caso de violência contra mulher, ou seja, os agentes públicos não são perpetuadores diretamente responsáveis por esse tipo de violência, mas o Estado é responsável por não prevenir e não punir. Logo, ao não prevenir ele possibilita que muitas vítimas sofram essa violação e ao não punir, ele possibilita que a própria sociedade não tenha consciência de que é muito grave alguém poder machucar e/ou estuprar a sua companheira. Nesse caso de litígio, nós entendemos como estratégico a perspectiva de mudança cultural e endêmica na nossa 
sociedade de percepções de certo e errado, consideramos que muitas das vezes que o êxito desses casos não é uma decisão internacional em si, mas todo processo político e toda reflexão social que vem à tona e que é colocada em cima da mesa. Portanto, é um tipo de litígio estratégico onde o processo é tão ou mais importante do que o resultado em si, isto é, da sentença ou da aplicação de uma política pública. No caso Maria da Penha ainda tem muita coisa a ser ajustada, mas foi um êxito enorme conseguir que a lei fosse elaborada, votada e promulgada. Percebemos então um outro parâmetro de litígio estratégico.

A questão do contexto pro CEJIL é muito importante, essa percepção de que os nossos clientes em $80 \%$ dos casos que litigamos pertencem à mesma classe social e que tem graves violações de direitos humanos perpetradas contra eles de diversas formas, como o não acesso a terra, violência física, restrição de liberdade, tortura, entre outros. Na verdade, eles perpassam um grupo social muito específico e caracterizado. Eles pertencem ao grupo que é considerado minoria, mas constitui a maioria discriminada em sua sociedade, quer dizer, a classe social menos favorecida. Isso não é um critério de escolha que faz parte do conceito de litígio estratégico, mas não dá pra desconsiderar que existe um recorte que não é o litígio estratégico que faz, mas senão é uma consequência de quando atuamos no $\mathrm{SIDH}$, já que $80 \%$ dos casos há a representação de pessoas que pertencem a esse grupo extremamente vulnerável na sociedade.

2) Como foi a atuação do CEJIL com as vítimas no decorrer do processo? Havia um acompanhamento?

Sobre a atuação do CEJIL no decorrer do processo depende das circunstâncias de cada caso. Mas, no caso da Brasil Verde, ela demora 20 anos, de 1996 até 2016 com a sentença. Os nossos copeticionários foram a Comissão Pastoral da Terra (CPT) que sempre teve muito mais proximidade, está em locus e tem relação direta como esses trabalhadores. 
Normalmente os trabalhadores em geral escravizados quando fogem pedem ajuda para a CPT.

Nós tivemos com o Frei Henri, nosso querido companheiro de trabalho e de luta, e a denúncia inicial do caso diz respeito ao desaparecimento de dois adolescentes que estavam na Fazenda Brasil Verde. Depois disso, a CPT acompanhou as várias fiscalizações, foram 16 fiscalizações em 12 anos na Brasil Verde e em 80\% dessas fiscalizações foram libertadas pessoas que estavam em situação análoga à escravidão contemporânea e sem nenhum tipo de fiscalização para o fazendeiro, gerente e capatazes durante todo esse tempo.

O Caso Brasil Verde durou 20 anos. Só no SIDH, as primeiras denúncias aconteceram em 1989, com o desaparecimento dos dois adolescentes. O caso tardou muito tempo para alcançar a denúncia no sistema e o tempo entre a denúncia da Comissão e a sentença na Corte IDH. $\mathrm{O}$ contato com as vítimas foi muito mais estreito com a CPT, que está em locus e que sempre recebeu os trabalhadores quando eles conseguem fugir, e muitas das vezes depois da fiscalização eles recebem os trabalhadores que foram libertados, além de acompanhar uma grande maioria dessas fiscalizações. Consequentemente o contato foi maior, especialmente, com a família dos dois rapazes que tinham desaparecido foi da CPT.

Existiu uma época que nós perdemos o contato com todos os trabalhadores, porque eles têm esse trabalho que é ocasional e eles buscam trabalhar nas fazendas em tempos em que existe a oferta da produção, no entanto, sempre na esperança de não passarem outra vez por situações tão delicadas como eles já tinham passado na Brasil Verde. Na verdade, perdemos o contato por um tempo, mas quando o caso estava mais no final da Comissão Interamericana, nós conseguimos restabelecer contato com a grande maioria.

O caso na Comissão Interamericana tinha mais de 300 vítimas porque na Comissão as fiscalizações anteriores a 1997 entraram pela não realização de justiça, mas de trabalho escravo confirmado pela Corte foi só 
com as vítimas das fiscalizações de 2000. Infelizmente, tínhamos uma representação maior na Comissão, mas que se reduziu quando o caso vai à Corte IDH, por causa do marco temporal do reconhecimento da jurisdição da Corte pelo Estado Brasileiro.

Então, quando o processo está no final da Comissão Interamericana, nós tivemos mais contato com os trabalhadores das fiscalizações mais recentes, uma vez que foram os mais fáceis de serem encontrados porque o endereço ainda coincidia. Esse contato não foi um contato homogêneo/permanente, ele foi um contato de altos e baixos, existiam algumas dificuldades que impossibilitavam uma comunicação regular, já que a grande maioria eram analfabetos, além da sua própria situação de trabalho. O acompanhamento se deu assim, mas aumentou quando passamos três anos tentando negociar um acordo de cumprimento do Relatório de Mérito da Comissão Interamericana. Nós tivemos o cuidado de contatá-los todos juntos e fazer diversas reuniões, então nesse momento se regularizou essa concepção entre eles de um grupo político que estava lutando pelos seus direitos

3) A sentença emitida pela Corte IDH atingiu com o objetivo almejado? A reparação sentenciada pela Corte cumpriu com a reparação integral das vítimas? Se não, por quê?

$\mathrm{Eu}$, como cientista social, acredito que esses processos são importantes de empoderamento dessas vítimas, por exemplo, nesse caso era um número enorme de pessoas que tinham, inclusive, sofrido a violação de forma coletiva porque habitavam no mesmo lugar, submetido nas mesmas condições degradantes e desumanas, e sofriam as mesmas violências físicas. No entanto, quando eles foram libertados e cada um seguiu a sua vida morando ainda na pequena cidade de Barras, no Piauí, mesmo assim eles tentavam esquecer aquela experiência coletiva, porque ela remetia a um momento de dor e, até mesmo com pouca consciência do nível de violação 
que significava aquilo, existia até uma naturalização de que às vezes podia dar errado aquelas reuniões e cair na mão de um "fazendeiro mal". Esse processo dos 3 anos da negociação do acordo foi de muito empoderamento e conscientização do que eles tinham vivido, e da obstrução de justiça - a denúncia de 1997 que chegou a virar uma denúncia judicial e que foi arquivada, onde o fazendeiro era testemunha e o réu era o gerente e o juiz entendeu que não tinha dito trabalho escravo e pediu o arquivamento em oposição à denúncia do Ministério Público Federal-.

Eles tiveram um grande empoderamento no processo, mas ninguém contabiliza esse aspecto como um todo. Eu contabilizo porque faz muita diferença que esses grupos possam ter uma visibilidade entre os seus pares e entre outros trabalhadores também. Eles passaram a se apropriar de uma linguagem dos seus direitos e compartilhar isso com o seu entorno, com sua classe social, com quem ele convive e com seus familiares, e isso é uma forma muito eficiente de conscientização política de massa. Eu considero que empoderamos um número bem importante de pessoas no interior do Piauí. No entanto, não posso te dizer qual vai ser o resultado que vai ter na prática, mas vai fazer muita diferença na forma como eles olham tudo a respeito do Estado, tudo a respeito dos seus próprios direitos e como eles se sentem hoje detentores da possibilidade de reclamar, isso é bastante coisa no caso deles.

Outra coisa importante dessa sentença é o aprofundamento do conceito de discriminação estrutural histórica. Nós temos um sistema interamericano que não tem uma prática de jurisprudência em direitos econômicos, culturais, sociais e ambientais, na verdade que tem poucas decisões a esse respeito. No caso da Brasil Verde foi aprofundado esse conceito estrutural, possibilitando a utilização dessa ferramenta para muitos outros casos de muitas outras naturezas e de muitos outros conceitos. Esse recorte de discriminação estrutural propicia/fomenta graves violações de direitos humanos e que o Estado é responsável por esse desequilíbrio e por não atuar de forma que esse grupo possa ser empoderado e possa receber 
políticas públicas especiais que não seja necessariamente de cotas. Ademais, é um perfil muito específico de jovens, em geral com um número importante de afrodescendente, todos analfabetos e que vivem em condições subumanas e abaixo da linha da pobreza, possuindo muitas características de vulnerabilidade. Esse foi um grande passo que nós tivemos e eu espero que ele possa ser aproveitado em vários outros casos, porque faz muito sentido em vários lugares, não necessariamente só no Norte ou Nordeste do Brasil. É um grande êxito ter avançado neste conceito.

Outro êxito foi conseguir delimitar o próprio conceito de trabalho escravo, visto que foi a primeira jurisprudência do Sistema Interamericano sobre essa temática. Temos o artigo 6 da Convenção, mas não tínhamos ainda uma jurisprudência que esclarecesse o que é o trabalho escravo.

Sabemos que há uma disputa com os setores interessados na permanência do trabalho escravo, onde eles chamam de "condições o que ainda não são modernas de produção". Esses setores são conhecidos no Brasil como bancados ruralistas. Além disso, há a discussão da questão da jornada exaustiva, condições de trabalho e de outras situações que não necessariamente dizem respeito à restrição de liberdade mediante intimidação ou ameaça física.

$\mathrm{O}$ conceito de trabalho escravo ficou bastante claro e não ficou restrito, apesar do Estado Brasileiro ter tentado isso, uma vez que atuou em defesa do fazendeiro com a mesma lógica da bancada ruralista, tentando restringir ao o que se previu com o Código Penal do conceito do crime de trabalho escravo, nas quais são as situações que podem ser concomitantes ou independentes que caracteriza o crime de trabalho escravo. Logo, podemos dizer que foi um êxito, porque já tínhamos o caso José Pereira que avançou muito, mas não tínhamos uma jurisprudência que dava limite, fortalecia e que trazia o conteúdo do que é trabalho escravo no Sistema Interamericano. Além disso, a sentença se estendeu para o tráfico de pessoas, tráfico de mulheres e exploração sexual. Porquanto, nesse caso 
ficou delimitado o modus operandi que caracteriza o tráfico de pessoas, não só para fins de trabalho escravo como exploração sexual de crianças.

A crítica à sentença do caso Brasil Verde é a ausência de determinação de políticas públicas. Realmente, para o CEJIL foi uma tristeza porque passamos 3 anos negociando um acordo de cumprimento do relatório de mérito da Comissão Interamericana que tinham 21 cláusulas, nas quais 19 eram de medidas de políticas públicas para fortalecimento dos instrumentos que já tínhamos de trabalho escravo, e visando criar novos instrumentos que se adequassem a esses para trazer uma resposta ainda mais efetiva seja na justiça, seja na prevenção, seja no tratamento dos trabalhadores que são os que potencialmente têm mais chances de serem escravizados, no trabalho com os trabalhadores que são libertados e nos municípios onde mais se recruta trabalhadores que são escravizados e libertos.

Ressalto que essas políticas públicas foram bem fundamentadas para a Corte e acredito que existia uma legitimidade objetiva em que a Corte concebesse políticas para a não repetição de graves violações de direitos humanos, como trabalho escravo, com esse material farto que foi essa negociação do acordo e o texto do acordo em si que continha as cláusulas com explicação do porque aquela política pública iria ajudar. Era um acordo para ser cumprido com o prazo de 2 anos.

Destaco que as políticas que tínhamos negociados não eram inovadoras ou que ninguém já tivesse visto, mas eram políticas que fortalecia o que já existia e as ampliava. Eram políticas factíveis e nem isso a Corte Interamericana absorveu. Existe uma coisa inexplicável que na minha perspectiva a única explicação de não ter dado nenhuma medida de repetição no caso Brasil Verde foi no momento em que a sentença saiu, especificadamente, no meio do impeachment da Presidente Dilma, com a tensão do Partido PMDB, da bancada ruralista e de todo o universo político do Brasil na época. Claramente essa tendência do Sistema Interamericano de não atuar de forma a interceder ainda que indiretamente nas políticas 
partidárias no País, apesar de termos feito profunda e amplamente no nosso escrito da denúncia para a Corte Interamericana.

Até agora o Estado Brasileiro cumpriu as determinações, o que a Corte determinou foi a reparação das vítimas, então todos aqueles que nós representamos, por volta de 85 pessoas, já receberam as indenizações pecuniárias no final do ano de 2017, entre o natal e ano novo. E as publicações em jornal de grande circulação devem sair nessa semana, quem sabe no dia 29 de junho de 2018, contendo a cópia do resumo da sentença do caso Brasil Verde que é um ponto que o Estado Brasileiro está devendo para a publicação. 